\title{
7. Stem anatomical structures of major taxonomic units
}

This chapter describes the anatomy of major stem-forming taxa within the taxonomic hierarchic system. This system has seven principal categories with specific endings on Latin names:

$\begin{array}{lll}\begin{array}{l}\text { Domain } \\ \text { Kingdom }\end{array} & \text { Eukarya } \\ \text { Division } & \text {-phyta (plants), -phycota (algae), -mycota (fungi) } & \text { e.g. Plantae, Fungi } \\ \text { Subdivision } & \text {-phytina (plants), -phycotina (algae), -mycotina (fungi) } & \text { e.g. Basidiomycota } \\ \text { Class } & \text { e.g. Lycopodiophytina } \\ \text { Order } & \text {-ales } & \text { e.g. Bryopsida, Coniferopsida } \\ \text { Family } & \text {-aceae } & \text { e.g. Magnoliales } \\ \text { Genus } & & \text { e.g. Rosaceae } \\ \text { Species } & & \text { e.g. Prunus } \\ \end{array}$

Described in this chapter are species of the following groups:

- Basidiomycota (fungi)

- Phaeophyceae (brown algae)

- Lichenes (lichens)

- Bryopsida (mosses) and Sphagnopsida (Sphagnum moss)

- Psilophytina (whisk ferns)

- Lycopodiophytina (several species of lycopods)

- Equisetophytina (several species of horsetails)

- Filicophytina (several species of ferns)

Fungi

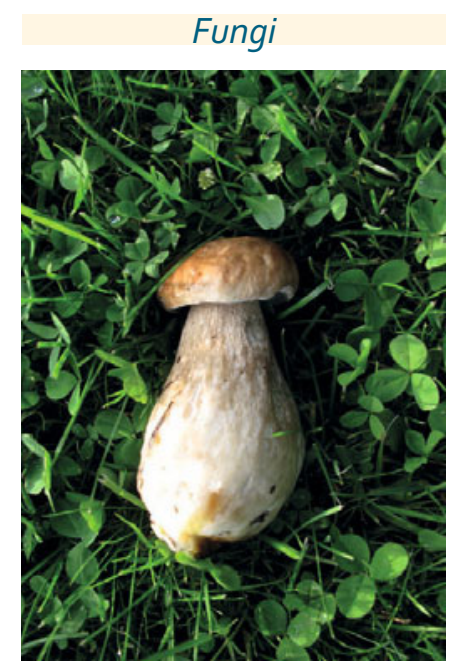

7.1 Division: Basidiomycota (Bole-

tus edulis)
- Spermatophyta (many species of seed plants):

Cycadopsida (some species of palm ferns)

Ginkgopsida (Ginkgo biloba)

Coniferopsida including Gnetales (some species of conifers, Ephedra, Gnetum, Welwitschia)

Angiosperms (many species of flowering plants) monocotyledons and dicotyledons (old term)

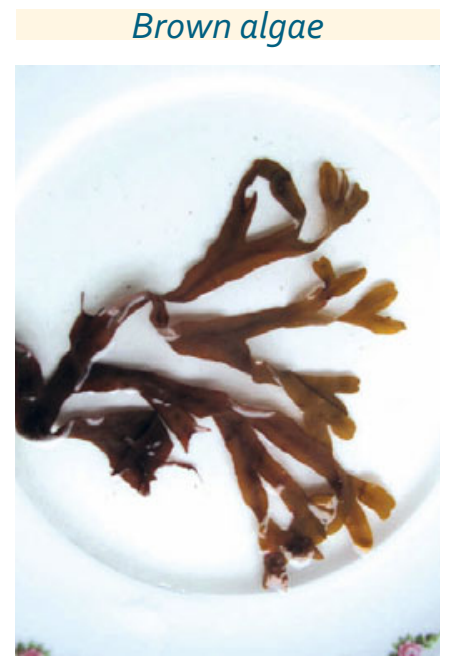

7.2 Class: Phaeophyceae
Lichens

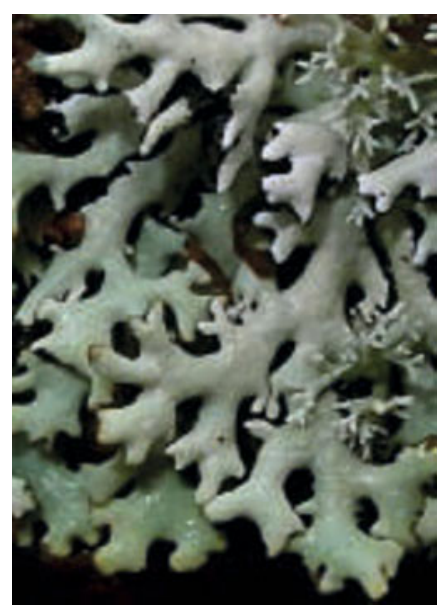

7.3 Lichenes
Mosses

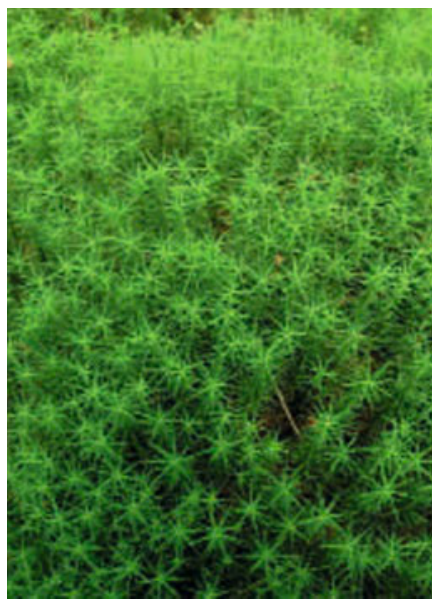

7.4 Class: Bryopsida 
Whisk ferns

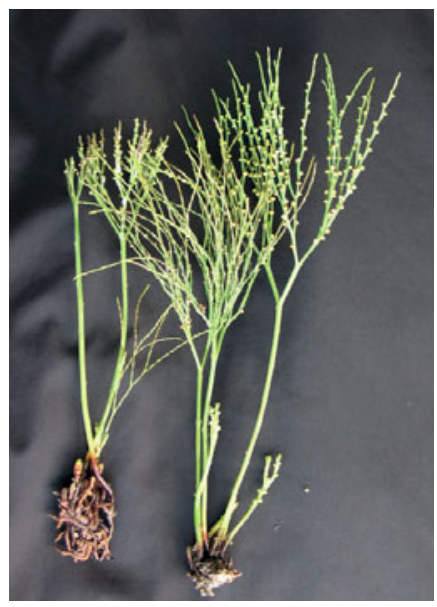

7.5 Subdivision: Psilophytina
Lycopods

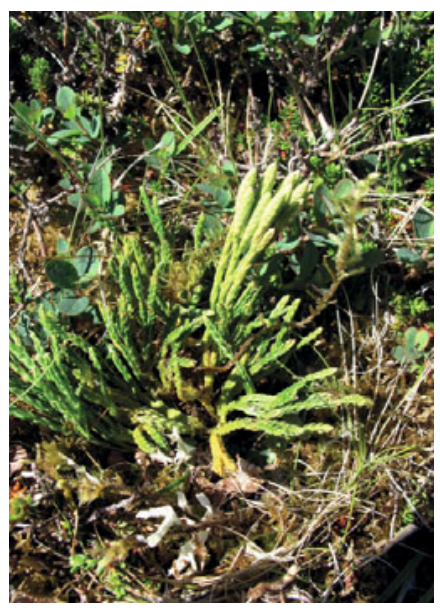

7.6 Subdivision: Lycopodiophytina
Horsetails

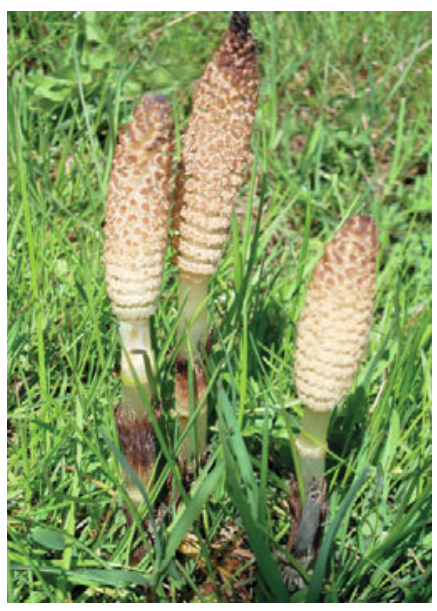

7.7 Subdivision: Equisetophytina
Ferns

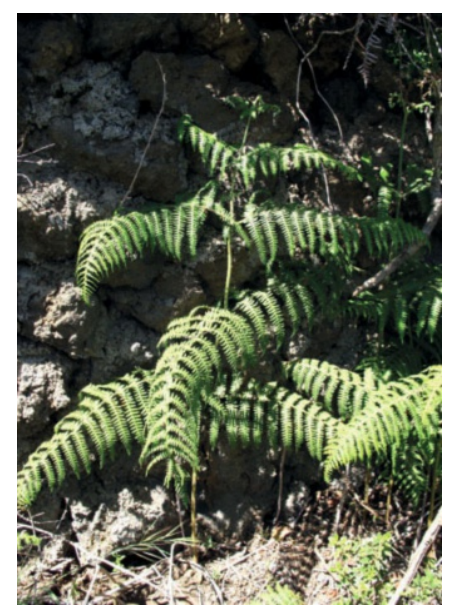

7.8 Subdivision: Filicophytina

Seed plants

Palm ferns

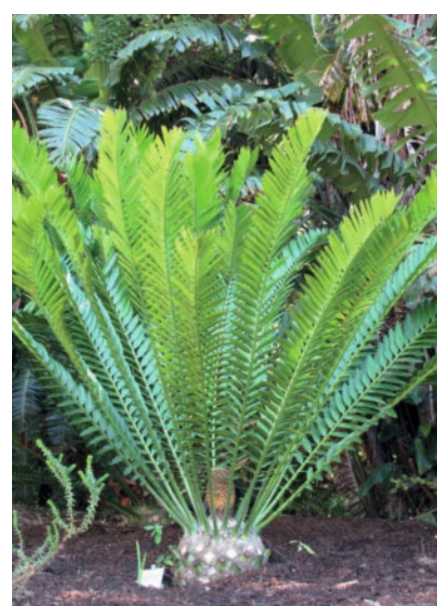

7.9 Class: Cycadopsida

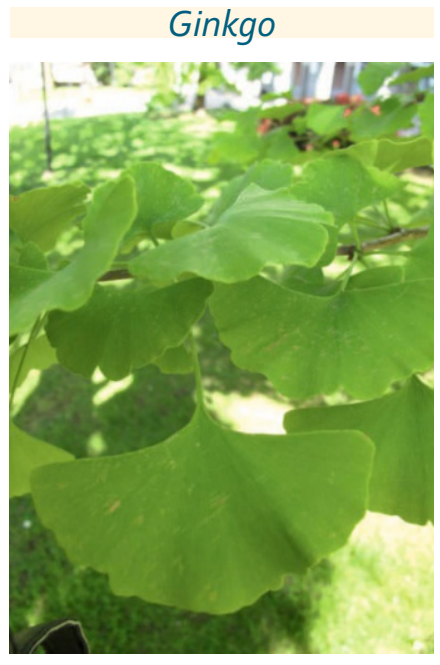

7.10 Class: Ginkgopsida
Conifers

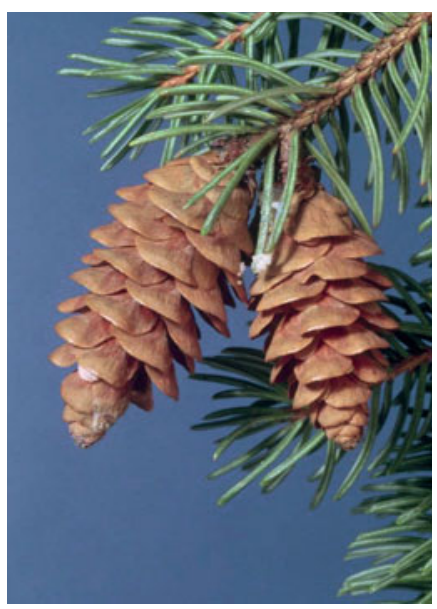

7.11 Class: Coniferopsida
Ephedra

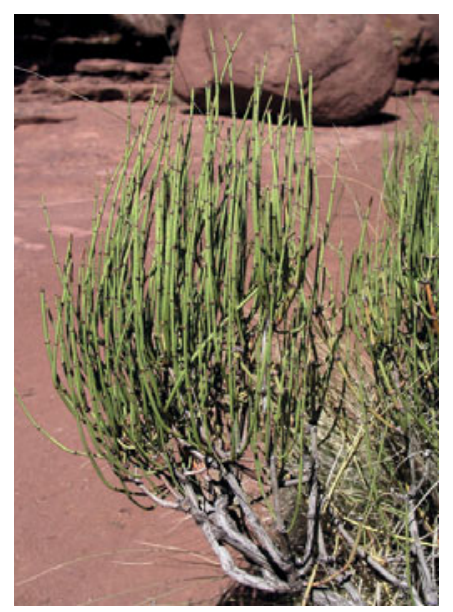

7.12 Order: Gnetales
Monocotyledons

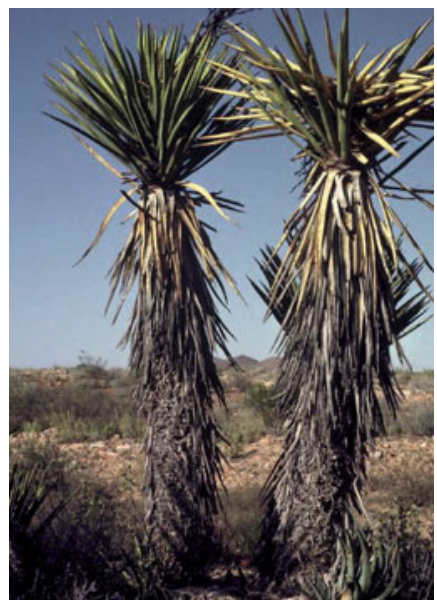

7.13 Angiosperms

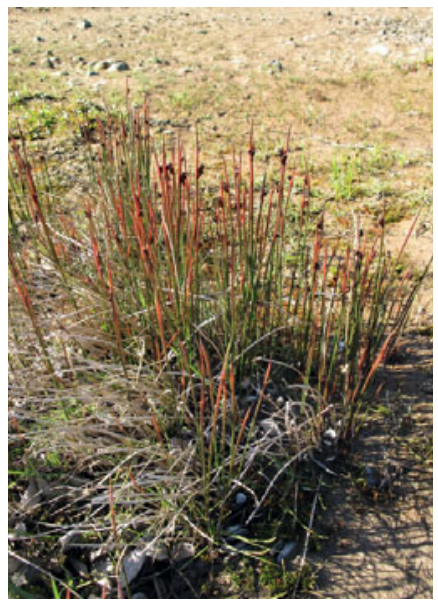

7.14 Angiosperms

Dicotyledons

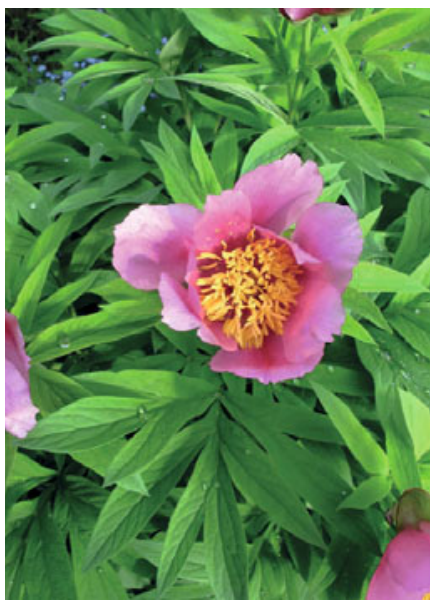

7.15 Angiosperms

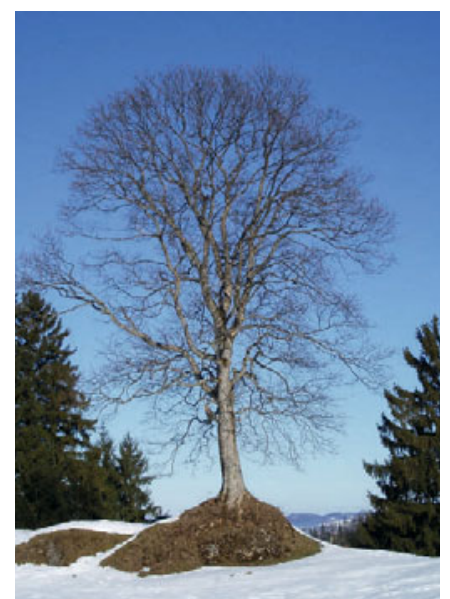

7.16 Angiosperms 


\subsection{Stem-forming fungi and algae}

\subsubsection{Sporophytes of fungi}

Described are microscopic structures of a few larger stems of fruiting bodies of Eubasidiomycetes. One cell type, the hyphae, form mushroom stems. The images demonstrate that the anatomical characteristics of hyphae create a great morphological diversity. Distribution, variation of density, orientation, diameter, wall thickness, chemical composition and different cell types determine the aspect and the construction of mushroom stems.

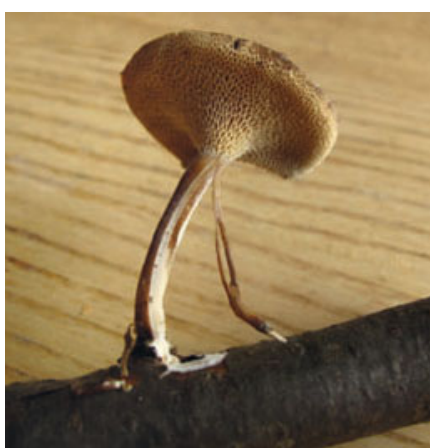

7.17 A 5 cm-tall Polyporus brumalis mushroom on a branch.

Microscopic aspect overview

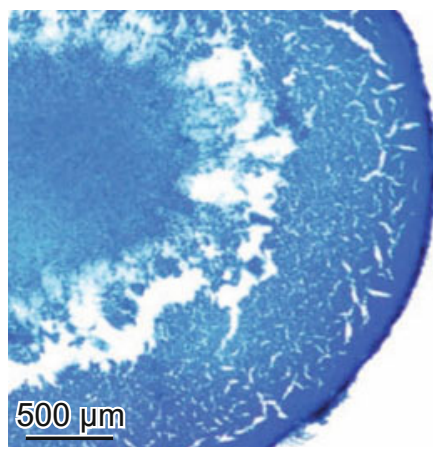

7.21 Cross section of a stem of Polyporus brumalis with a dense peripheral layer, middle layer with few hyphae, and central strand of hyphae.

\section{Macroscopic aspect of fungal fruiting bodies with stems}

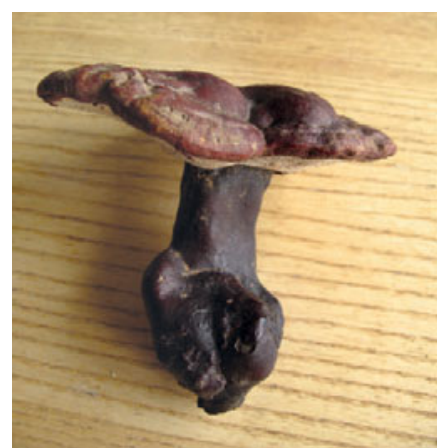

7.18 A 12 cm-tall Ganoderma carnosum mushroom, which grows on dead wood of Abies alba.

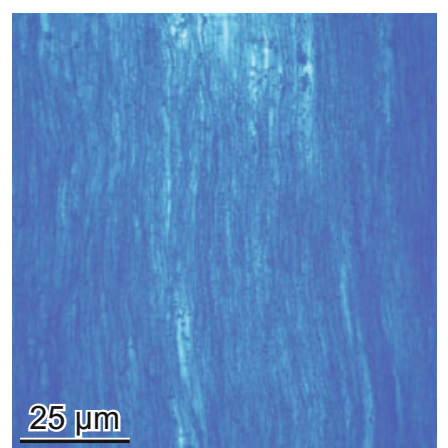

7.22 Axially and parallel orientated hyphae in the peripheral zone of Polyporus brumalis.

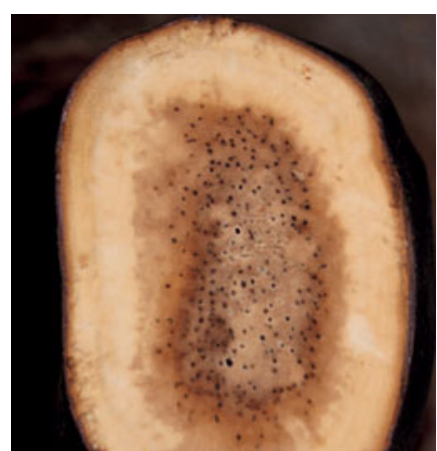

7.19 Cross section of a stem of Ganoderma carnosum with a dark peripheral layer, lighter outer part and brown center with longitudinal tubes.

\section{Orientation of hyphae}

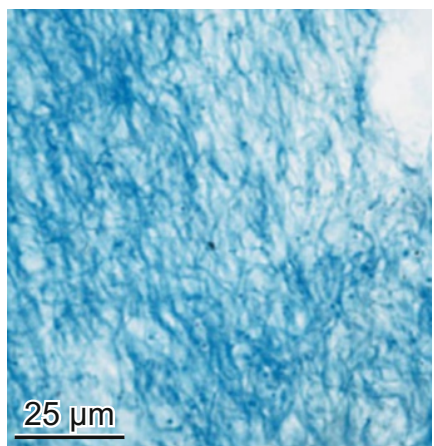

7.23 Radially oriented hyphae in the peripheral zone of Ganoderma carnosum.

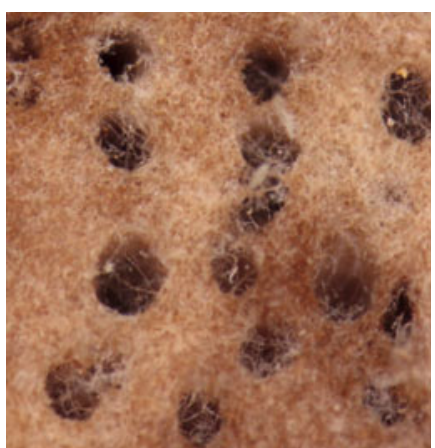

7.20 Irregular distribution of hyphae around the holes in the central stem part of Ganoderma carnosum.

\section{Diameter and wall density of hyphae}

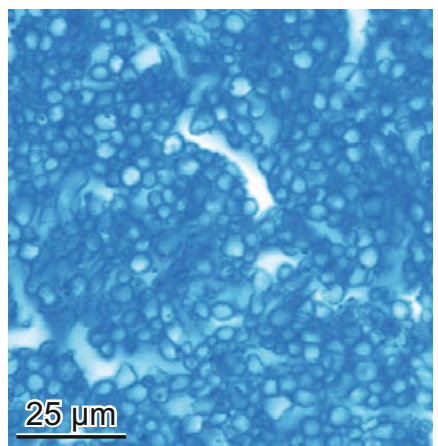

7.25 Cross section of large and thick-walled hyphae with 2-3 $\mu \mathrm{m}$ diameter in the peripheral layer of Polyporus brumalis.

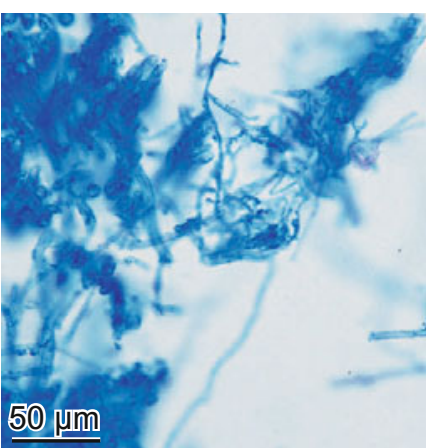

7.26 Occurrence of hyphae with different diameters in the middle layer of a cross section of Polyporus brumalis.

\section{Composition of stems}

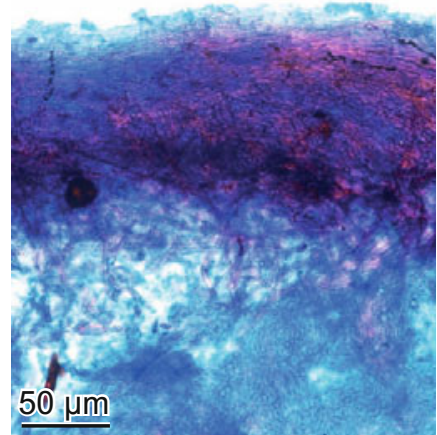

7.27 Red-stained peripheral layer and blue-stained central parts of the stem of Boletus edulis (Astrablue/ Safranin-stained).

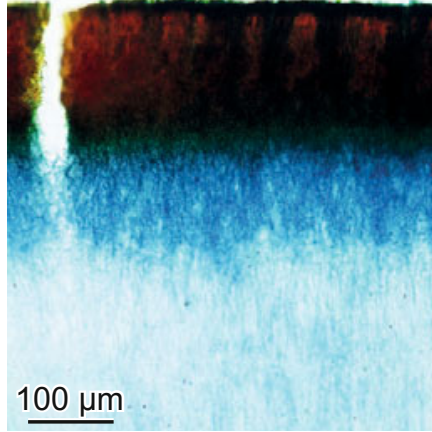

7.28 Brown-stained peripheral and blue-stained central layers of Ganoderma carnosum (Astrablue/ Safranin-stained). 


\subsubsection{Thalli and stems of brown algae}

Described are a thallus and stems of brown algae. Large thallusforming brown algae primarily occupy rocky, permanently or temporally submerse coastal sites (benthos) of temperate and cold oceans.

Coastal brown algae are anchored with rhizoids, and form stems (cauloids) and leaves (phylloids) of various lengths. Small plants remain a few centimeter tall, very large ones, e.g. the giant kelp, can reach a length of up to 40 meters. The principal stem construction of all types is similar. The cortex consists of cells filled with chloroplasts and brown substances (fucoxanthin) and a large center with less stained cells. The cellular structure is homogeneous in stems of small algae. Stems of Laminaria species in cold oceans are special, in that central, living cells form annual rings in a seasonal rhythm. It is a type of primitive secondary growth. Cell walls consist of a dense layer of cellulose fibrils and a mucilaginous layer of alginate (a polysaccharide). Stability is provided by the cellulosic layer, while flexibility is provided by the alginate. Peripheral cells contain photosynthetically active chloroplasts.

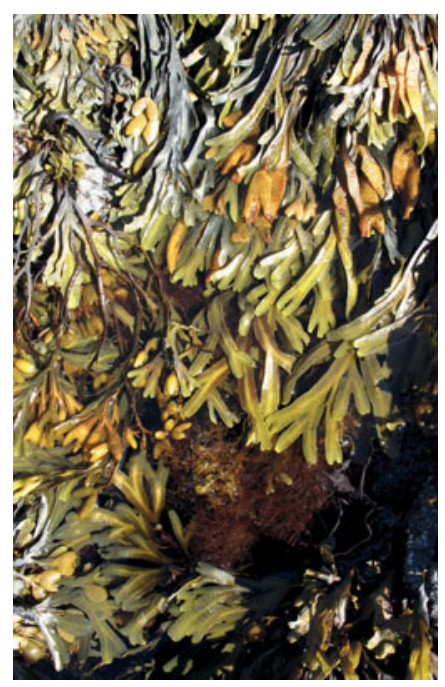

7.29 Fucus serratus at a sea shore in Iceland.

\section{Annual rings}

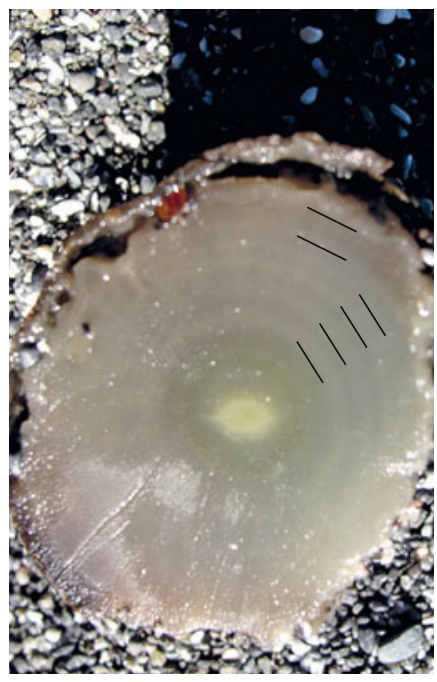

7.32 Cross section of a Laminaria sp. stem with 6 annual rings.

\section{Macroscopic aspect of large brown algae}

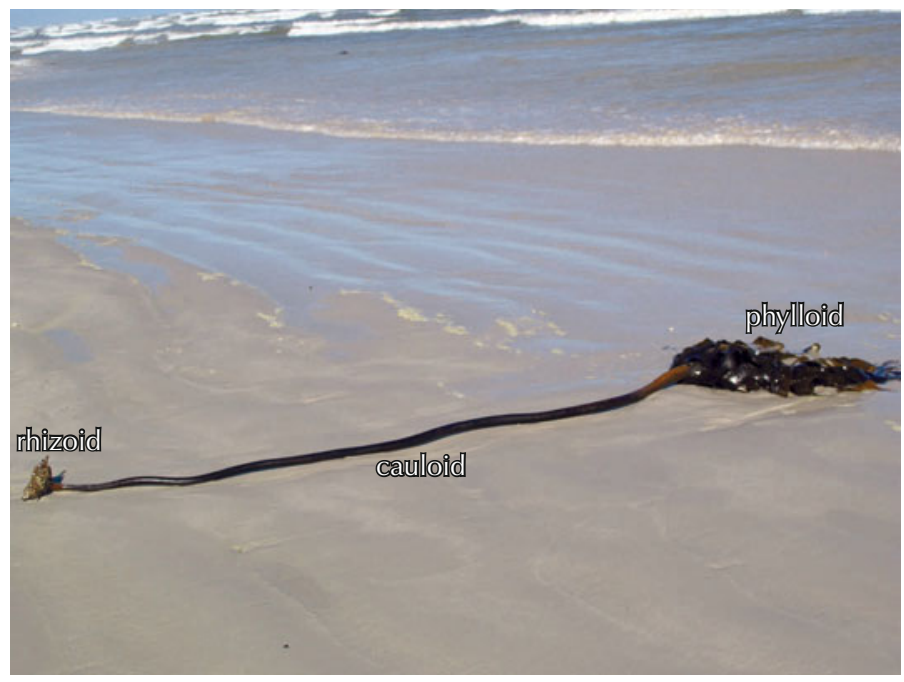

7.30 Washed-up, 6 m-long Macrocystis pyrifera (giant kelp) on the coast of South Africa.

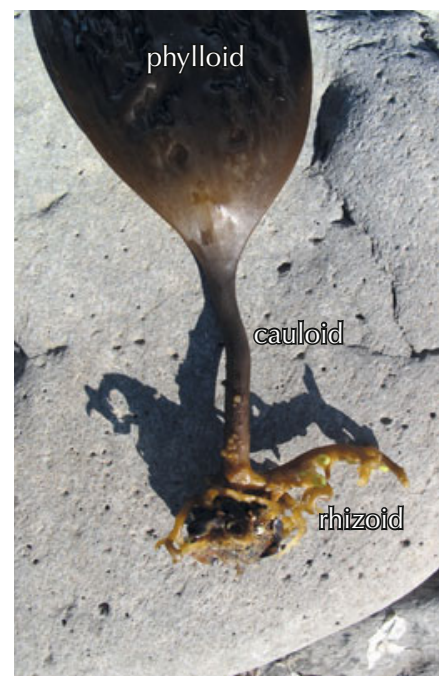

7.31 Phylloid (leaf), cauloid (stem) and rhizoids (roots) of Laminaria sp. on a rocky site in Iceland.

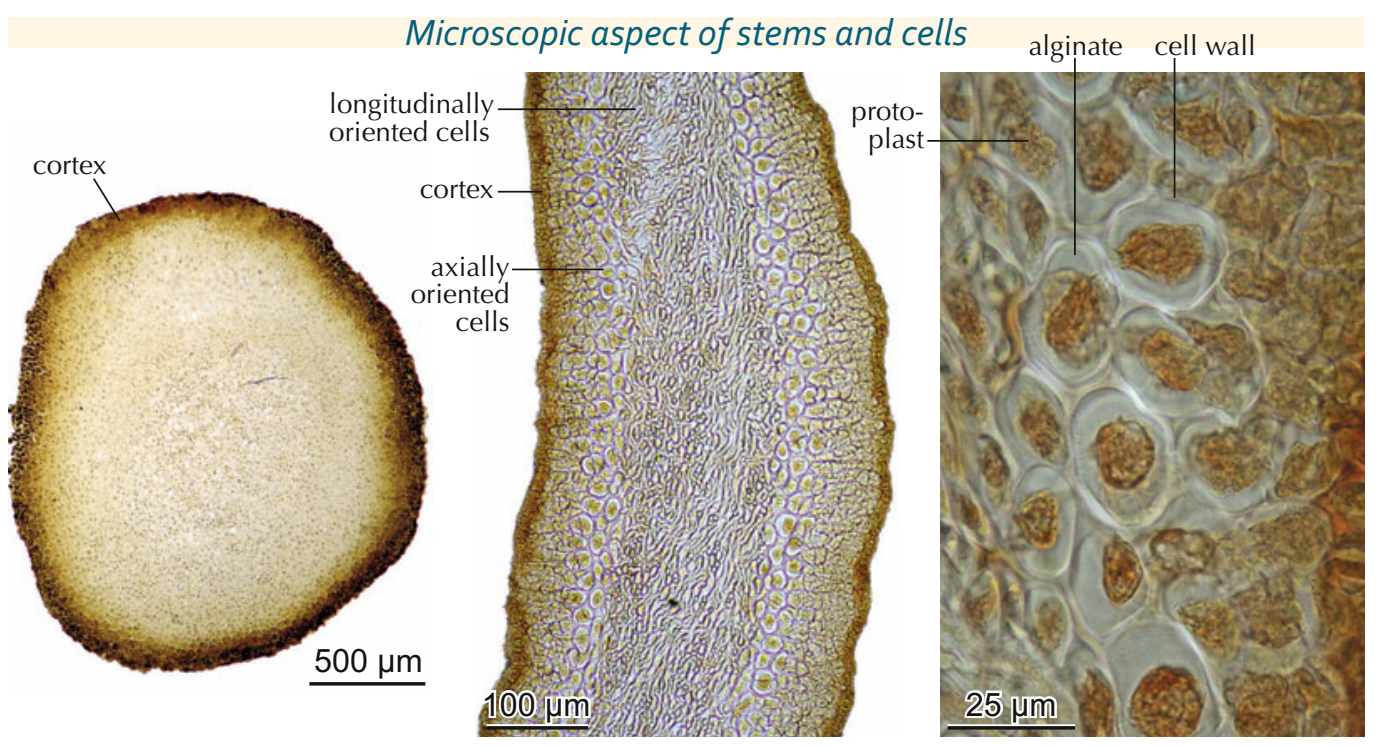

7.33 Cross section of a $5 \mathrm{~cm}$-tall stem forming tree-like brown algae.
7.34 Cross section of a $15 \mathrm{~cm}$-tall tallus of Fucus serratus. Peripheral cells are axially, central cells longitudinally oriented.
7.35 Fucus serratus cells with chloroplasts in the protoplast and double-layered walls. 


\subsection{Mosses - The oldest living plants}

Described are stems of mosses (Bryopsida), a peat moss (Sphagnopsida) and a liverwort (Marchantiopsida). They include approximately 20,000 species and occupy all sites from the tropics to the arctic, and from dry to submersed sites.

The principal stem structure of mosses and peat mosses is similar. An epidermis and a mantle of fiber-like cells with various wall thickness surrounds a parenchymatic center. Parenchyma cells can be perforated by simple pits. This is the structure of the simplest types. Some species have developed a central strand consisting of leptoids, and others of leptoids and hydroids. Leptoids conduct photosynthetic products, the hydroids conduct water. The central parenchyma cells of most species are not perforated. Simple pits with large apertures could only be observed in a few walls. Leptoids are unlignifed, longitudinally enlarged cells with horizontal walls. Hydroids in Polytrichum sp. are longitudinally enlarged, lignified, fiber-like cells without pits.

The peat mosses belong to the simplest anatomical type, however, the mantle is divided into a very thin-walled peripheral and a thick-walled inner part.

The thallus of Marchantia sp. resembles a leaf rather than a stem. It consists of a layer of large parenchyma cells with large, simple pits and few oil cells. The top layer is composed of small cells with chloroplasts.

Mono- and multicellular extrusions of the epidermis cells, the rhizoids, occur on all observed species.

\section{Principal structure of moss stems}

\section{Types with an undifferentiated center}

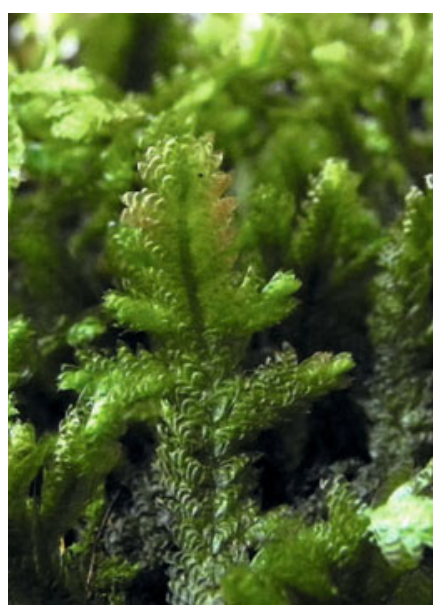

7.36 Neckera crispa. Photo: A. Bergamini.

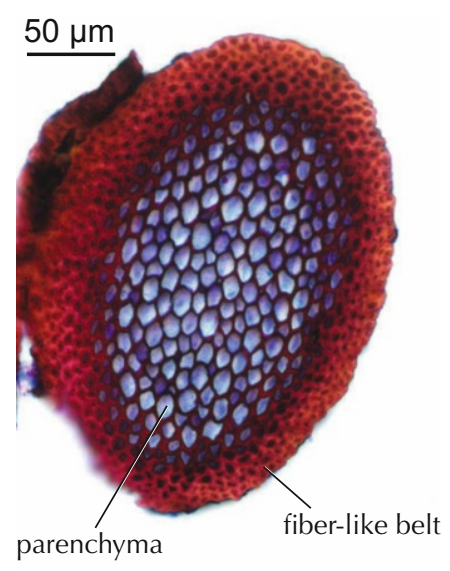

7.37 Stem of Neckera crispa with a thick-walled mantle.

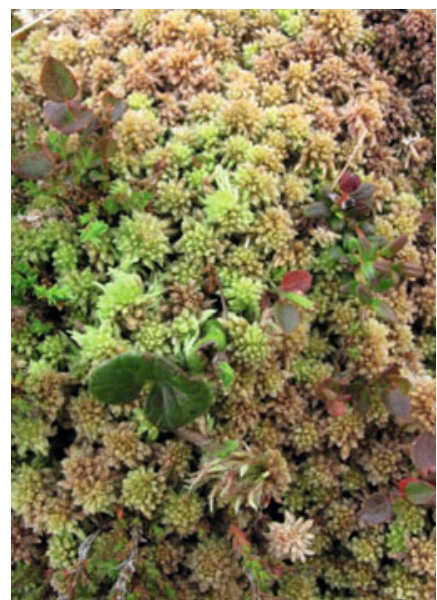

7.38 Sphagnum compactum.

\section{Types with leptoids and hydroids in the center}

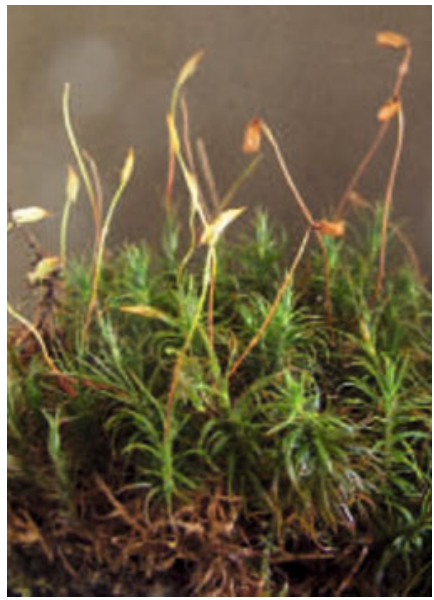

7.42 Polytrichum commune.

7.41 Stem of Funaria hygrometrica with a mantle of thick-walled cells and leptoids in the center.

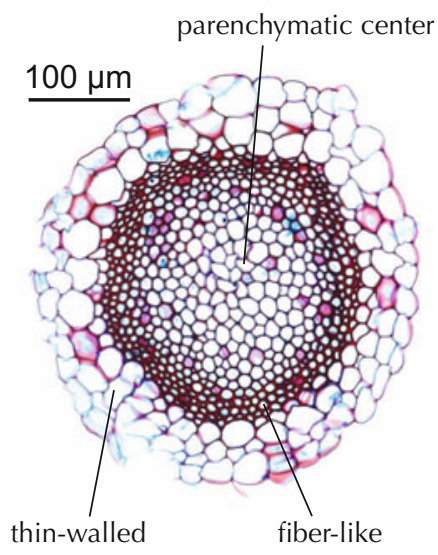

7.39 Stem of Sphagnum subnitens with a mantle of thin- and thickwalled cells.

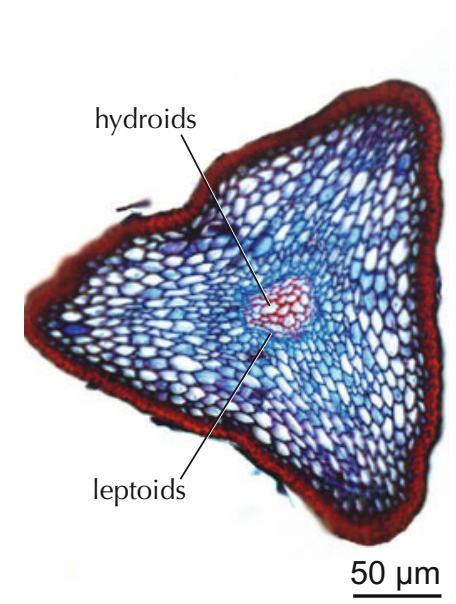

7.43 Polytrichum commune with a mantle of thick-walled cells and a center of hydroids and leptoids. 
Types with a thallus

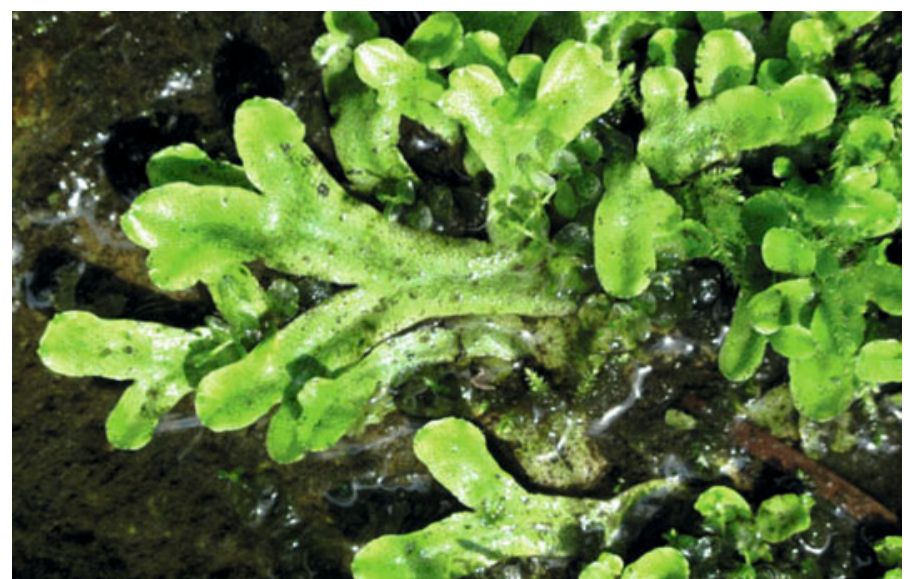

7.44 Marchantia polymorpha.

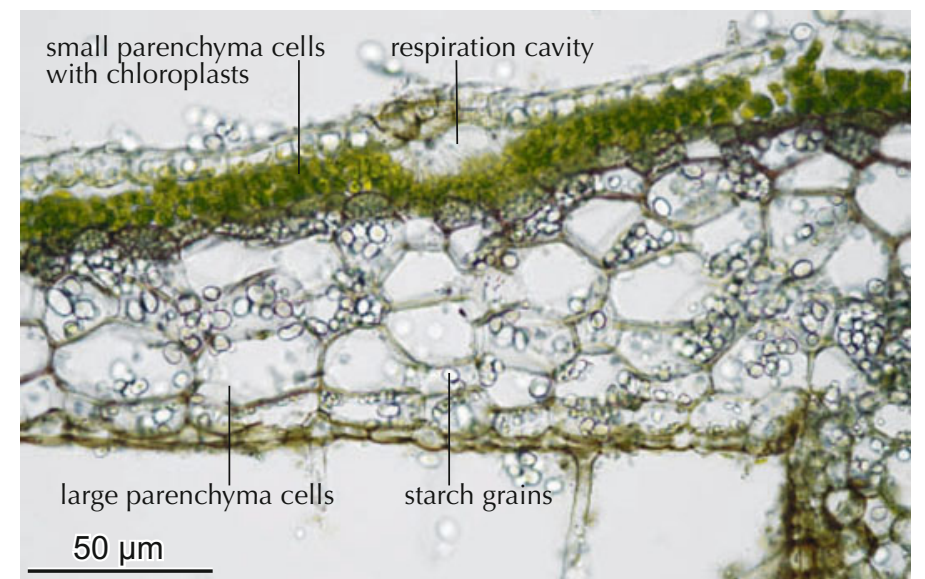

7.45 Thallus of Marchantia polymorpha with chloroplasts and a respiration cavern in the top layer. Starch grains in large parenchyma cells and rhizoids a the base of the thallus. Unstained slide.
Principal cell structure of moss stems

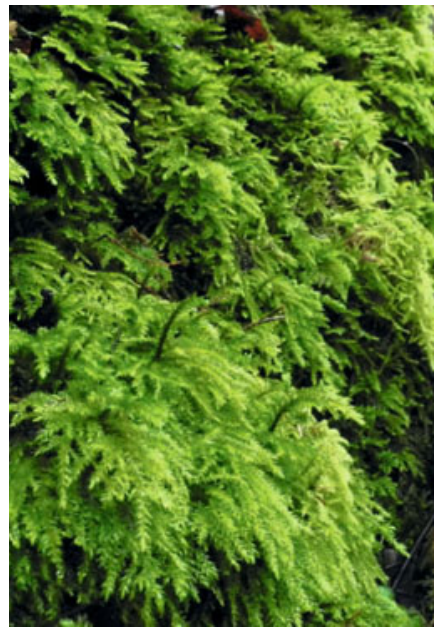

7.46 Thamnobryum alopecurum. Photo: A. Bergamini. parenchyma

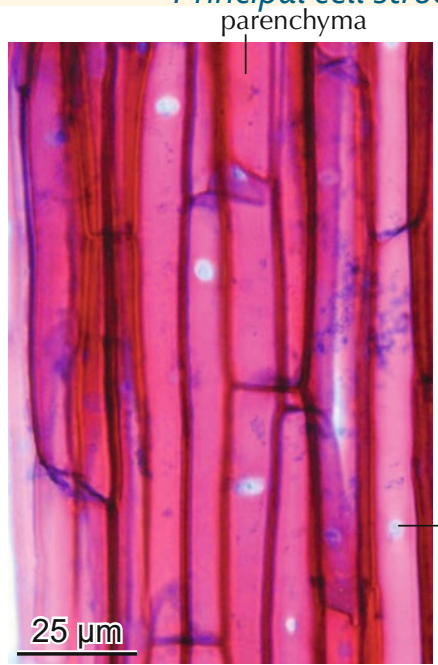

7.47 Parenchyma cells with large simple pits in Thamnobryum alopecurum.

Principal cell structure of moss stems

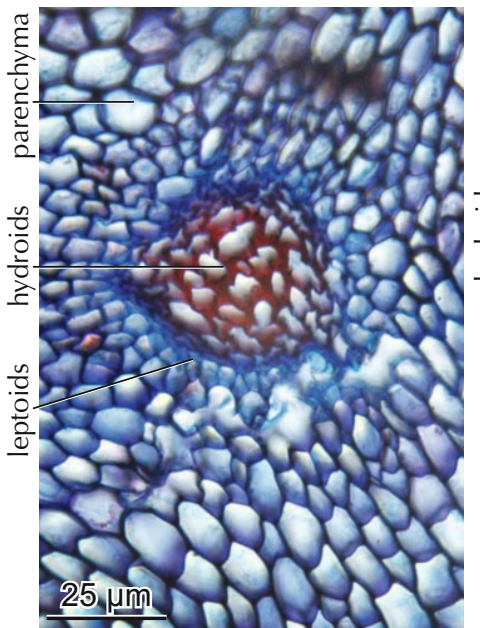

7.50 Unlignified leptoids and redstained (lignified?) hydroids are surrounded by unlignified parenchyma cells in Polytrichum commune.

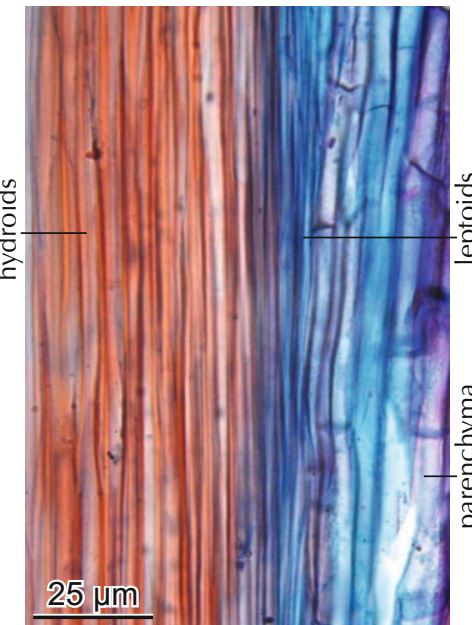

7.51 Lignified fiber-like hydroids, unlignified leptoids and parenchyma cells with horizontal walls in Polytrichum commune.

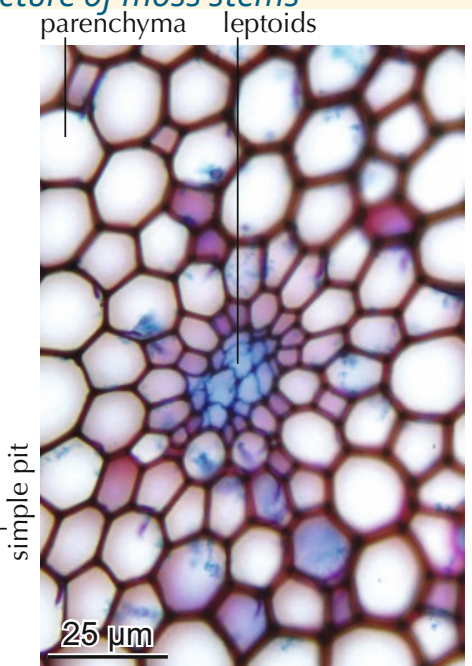

7.48 Unlignified leptoids in Thamnobryum alopecurum.

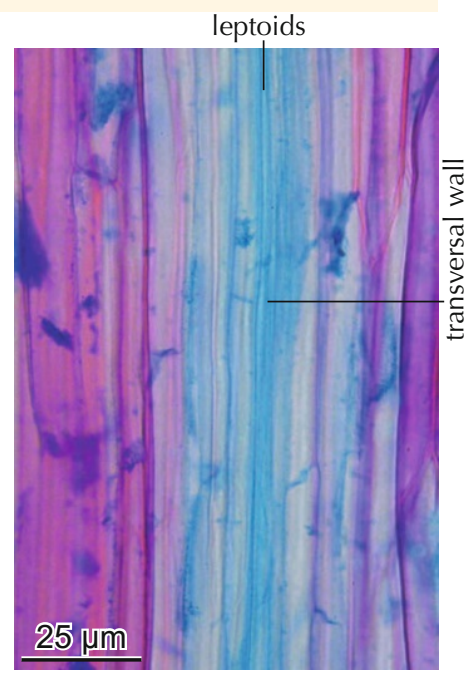

7.49 Unlignified, $300 \mu \mathrm{m}$ long leptoid with transverse walls in Tham nobryum alopecurum.

Rhizoids

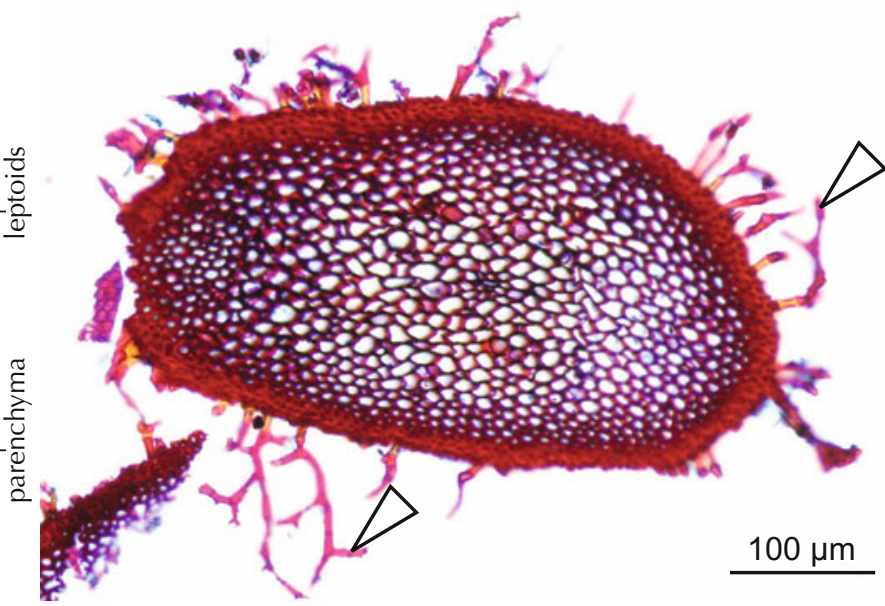

7.52 Rhizoids are specialized epidermis cells. Thuidium tamariscinum. 


\subsection{Fern-like plants}

\subsubsection{Spikemosses, quillworts and clubmosses}

Described are a few stems of the terrestrial genera Selaginella (spikemoss), Lycopodium (clubmoss) and the bulb of the swamp plant Isoetes (quillwort). They all have in common the absence of secondary growth, as well as the presence of concentric vascular bundles with a central xylem and a peripheral phloem. The xylem consists of tracheids with sclariform pits.

\section{Selaginellaceae (spikemosses)}

This family contains approximately 40 species. All of them belong to the genus Selaginella. Their stems are characterized
The families Selaginellaceae, Lycopodiaceae and Isoetaceae are distinguishable by the distribution of vascular bundles in the central strand (stele), and the individual species by the composition of the cortex and the form of vascular bundles.

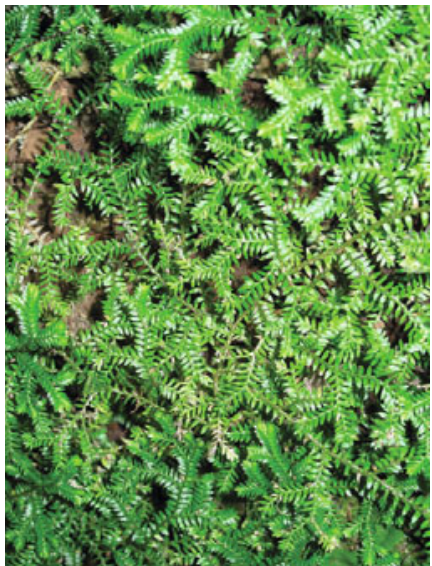

7.53 Selaginella denticulata.

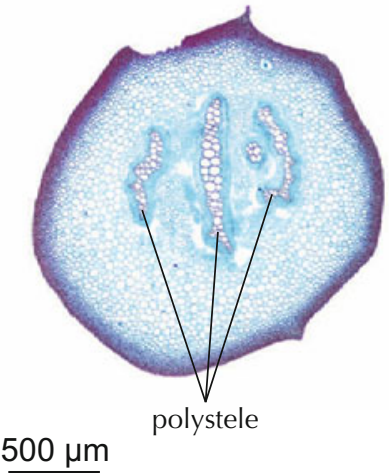

7.54 Stem of Selaginella sp. with isolated concentric vascular bundles. by the presence of single, laterally extended vascular bundles (polystele), which are surrounded by an endodermis.

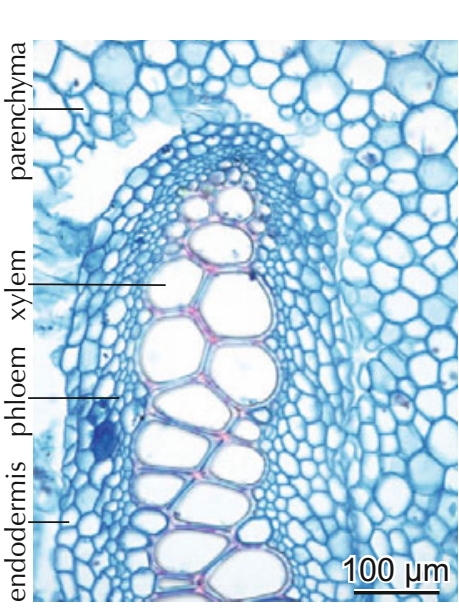

7.55 Part of a vascular bundle in Selaginella sp.

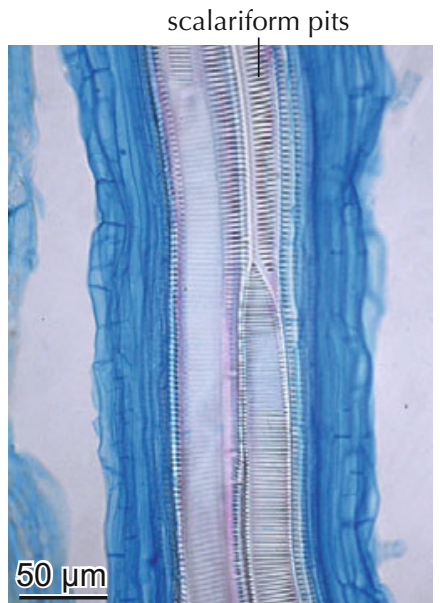

7.56 Tracheids with scalariform pits in a longitudinal section of Selaginella sp.

\section{Isoetaceae (quillworts)}

This family contains approximately 50 species. All of them belong to the genus Isoetes. They grow on wet sites. The bulb of Isoetes lacustris contains a central circle of tracheids where many laterally oblique emerging shoots are initiated. The

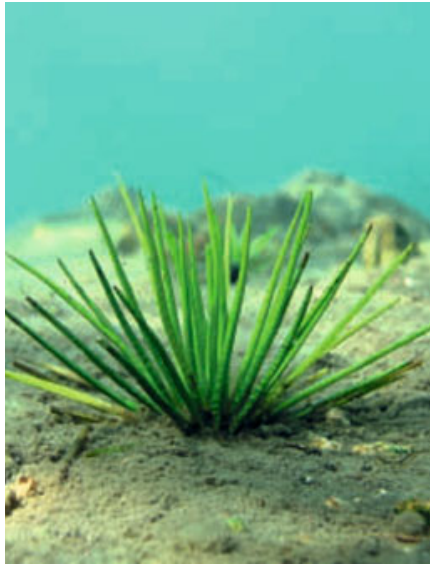

7.57 Isoetes lacustris. Photo: M. Ctvrtlikova.

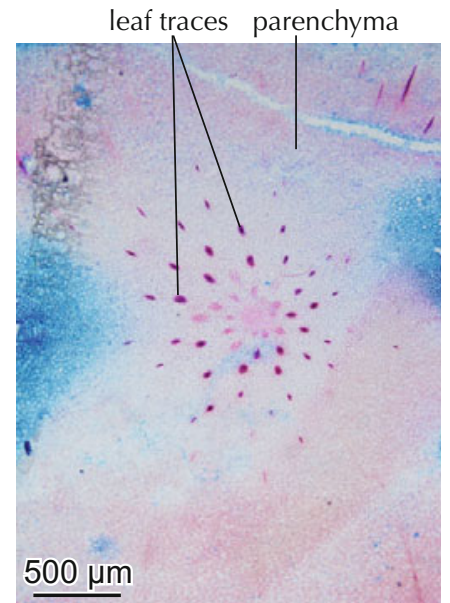

7.58 A central strand and many leaf traces are embedded in a thinwalled parenchymatic tissue in Isoetes lacustris.

vascular bundles are embedded in a very thin-walled parenchymatic tissue. The walls of tracheids are characterized by intensively lignified annular structures. An endodermis is absent.

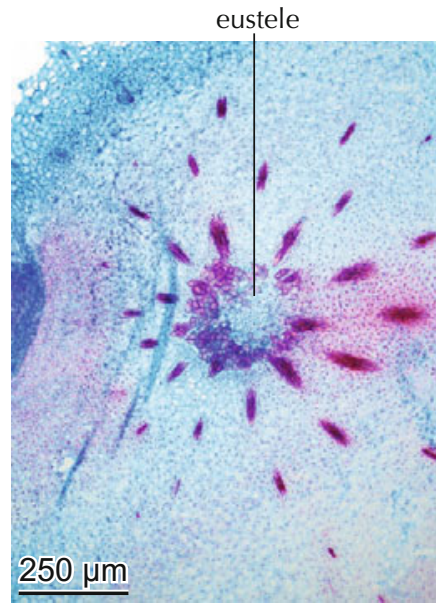

7.59 The central ring consists of circular arranged tracheids in Isoetes lacustris.

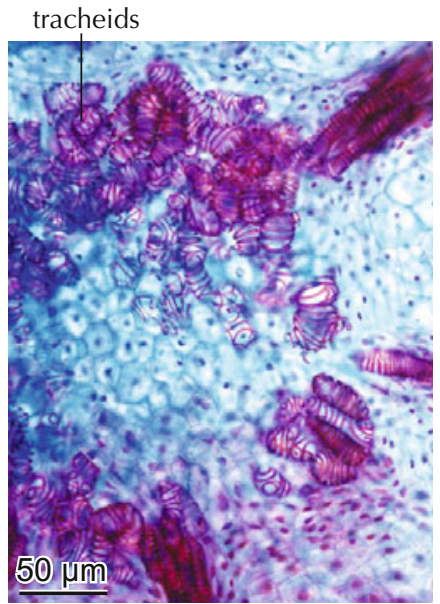

7.60 Tracheids with scalariform pits in the central strand in Isoetes lacustris. 
Lycopodiaceae (clubmosses)

This family contains more than 10 genera and approximately 1,000 species. Stems of clubmosses are characterized by a large cortex and a central strand with vascular bundles. The strand is

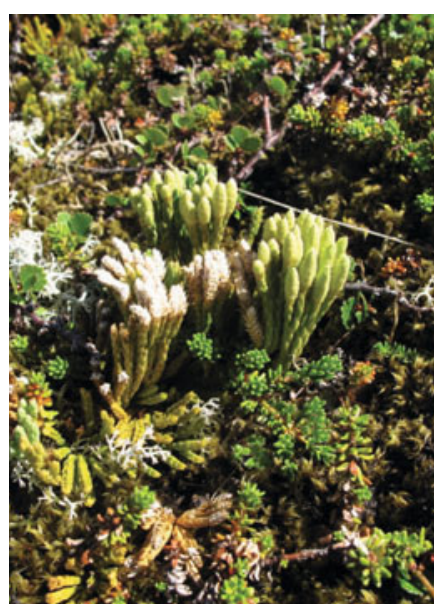

7.61 Lycopodium alpinum, an alpine cushion plant on dry sites.

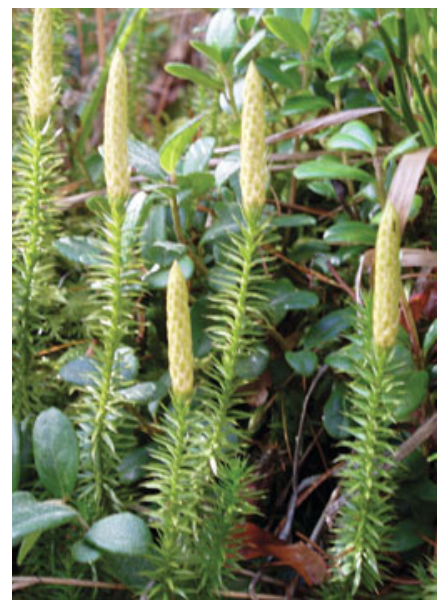

7.65 Lycopodium annotinum, a subalpine plant with long rhizomes.

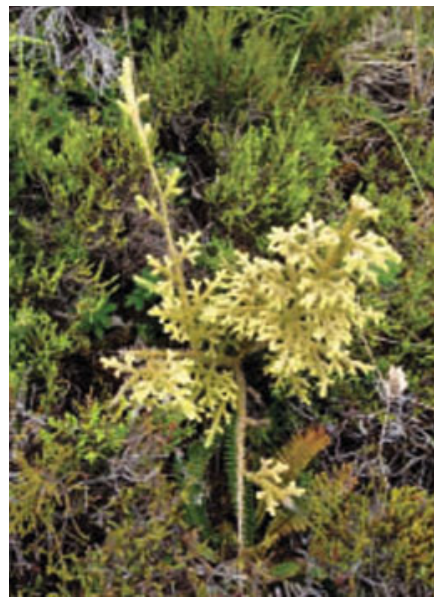

7.69 Lycopodiella cernua, an upright plant on subalpine bogs (Azores) scalariform pits

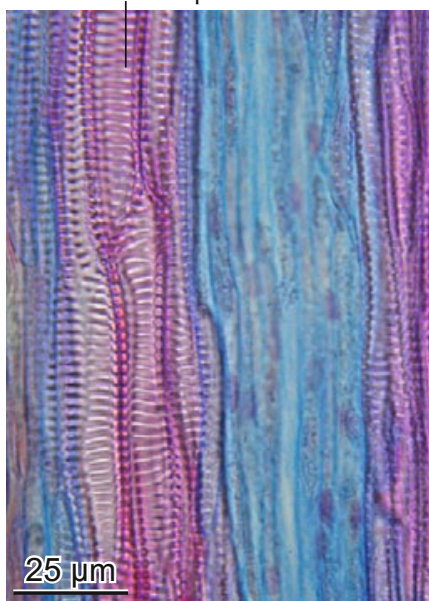

7.62 Scalariform pits on the walls of tracheids in Lycopodium alpinum.

scalariform pits

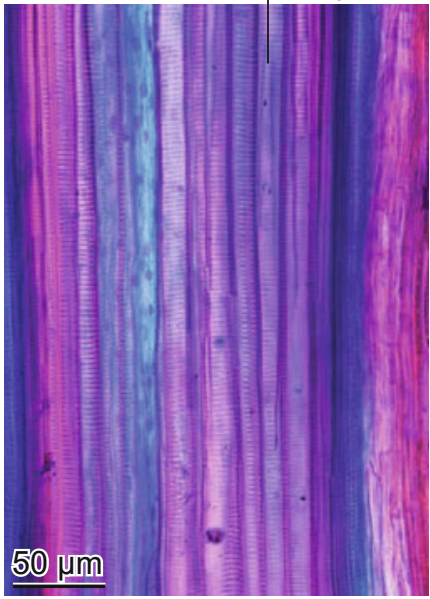

7.66 Scalariform pits on the walls of tracheids in Lycopodium annotinum.

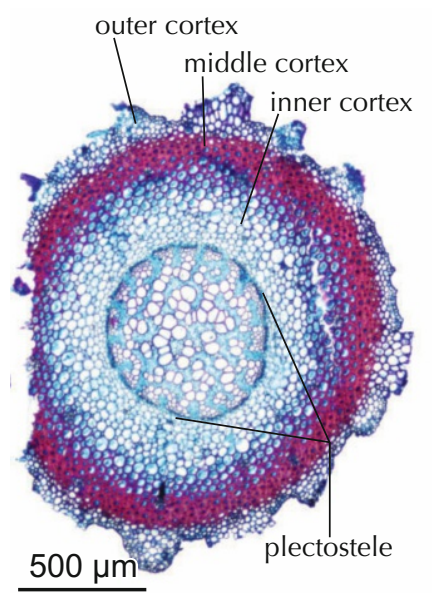

7.70 The central strand with a surrounding three-part cortex in LyCOpodiella cernua. surrounded by an endodermis. Different compositions of the cortex and distribution patterns of the central vascular bundles allow species identification.
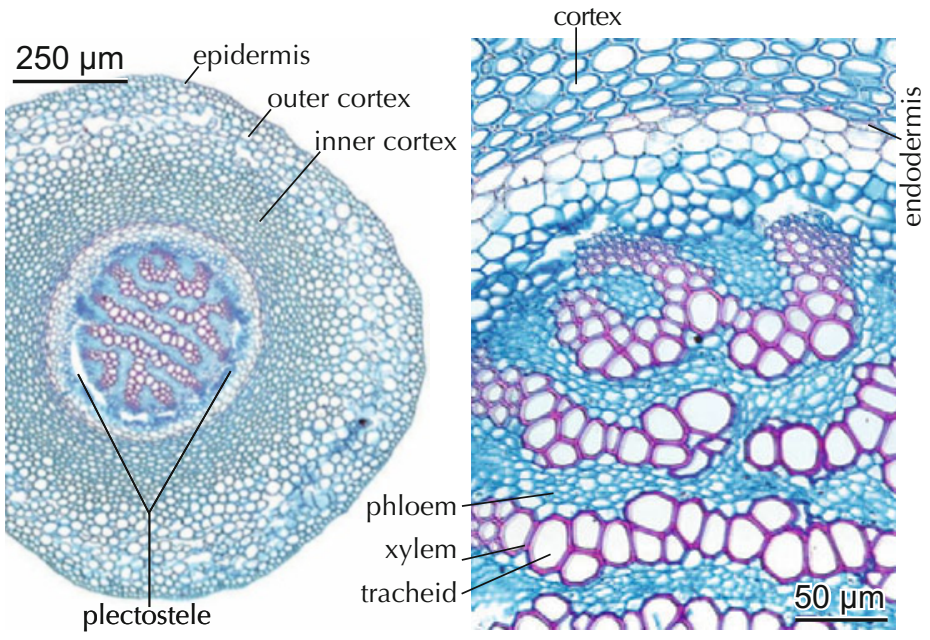

7.63 The central strand (stele) with a large surrounding cortex in $\mathrm{LyCO}^{-}$ podium alpinum.

7.64 Vascular bundles within the central plectostele in Lycopodium alpinum
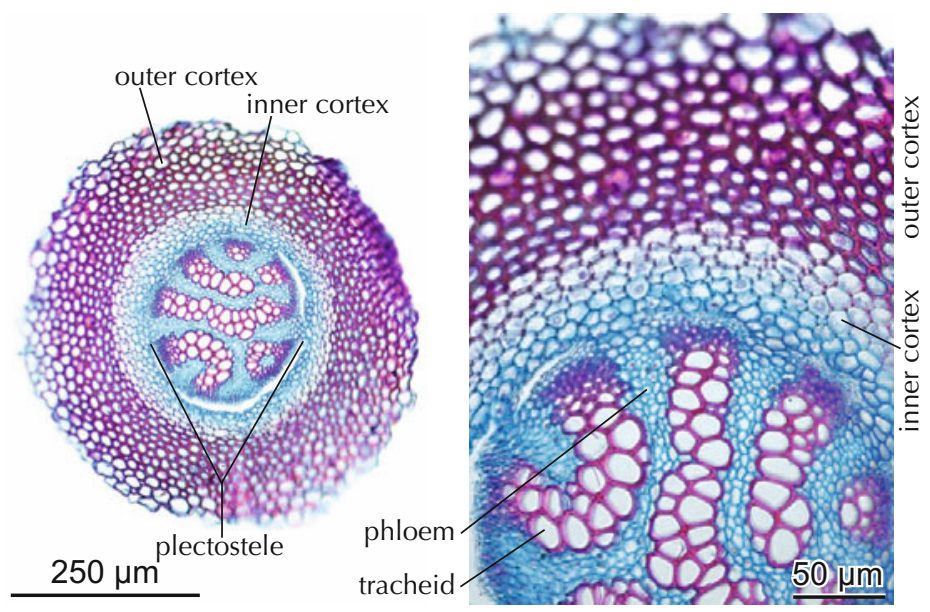

7.67 The central strand (stele) with

7.68 Vascular bundles with a central plectostele in Lycopodium dium annotinum.

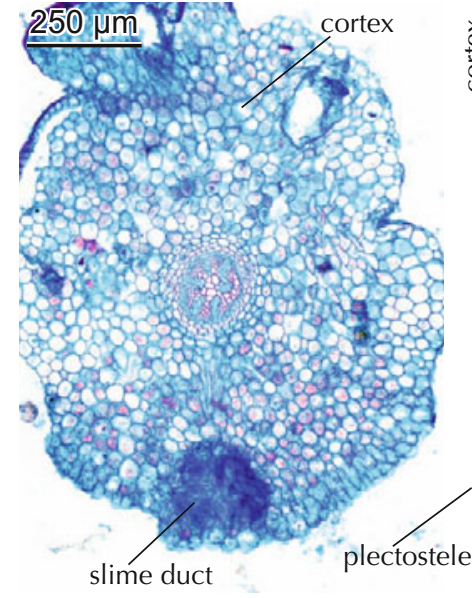

7.71 Large, thin-walled cortex and slime ducts in Lycopodiella innundatum, a bog plant.

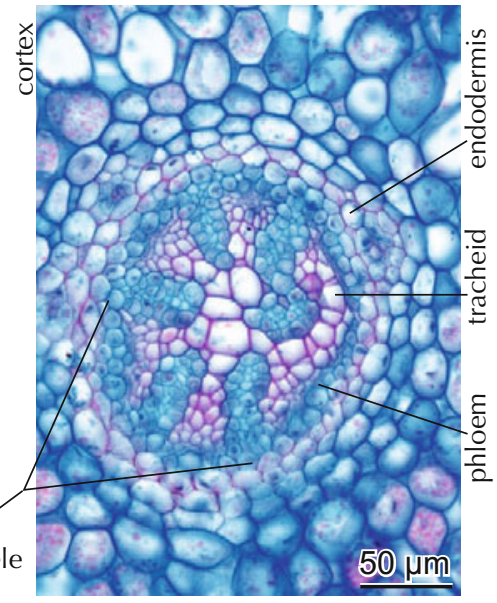

7.72 Vascular bundles with a central plectostele in Lycopodiella innundatum. 
Described are two terrestrial species: Psilotum nudum of the family Psilotaceae (whisk ferns) and Botrychium lunaria of the family Ophioglassaceae (moonworts). The family Psilotaceae contains two genera with three species, and the family Ophioglossacea contains four genera with approximately 80 species.

Representatives of the two families differ significantly from each other. Psilotum nudum is anatomically close to the lycopods, however, two features are different: the tracheids have scalariform and round pits, and the vessels are arranged star-like around a sclerified pith (actinostele). This is characteristic for
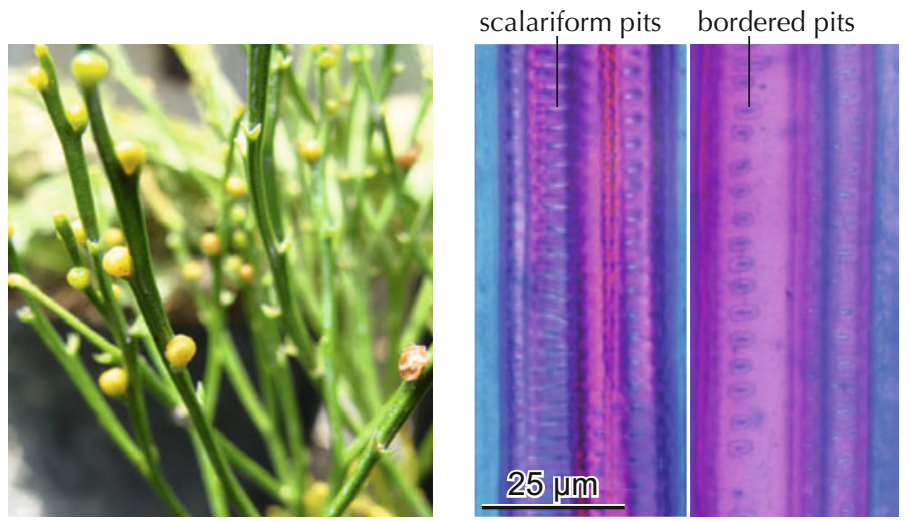

7.73 Psilotum nudum

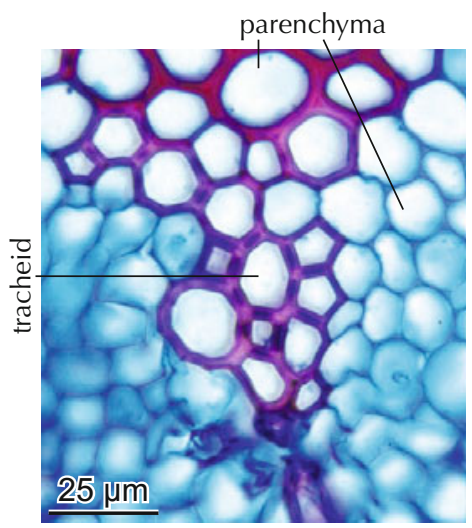

7.77 Groups of vessels at the tips of the star in Psilotum nudum.

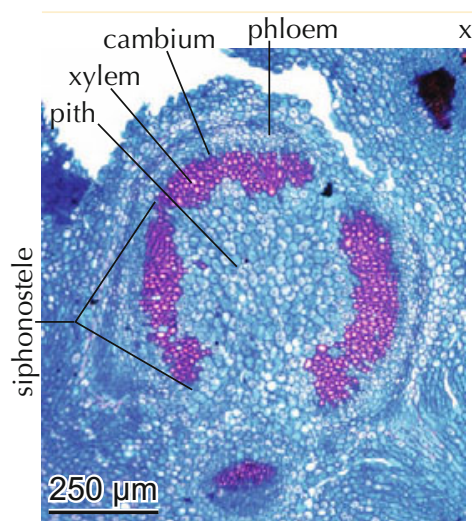

7.81 Tube-like arrangement of vessels (siphonostele) in Botrychium lunaria. 7.74 Scalariform vessel pits (left) and bordered pits (right) in Psilotum nudum.

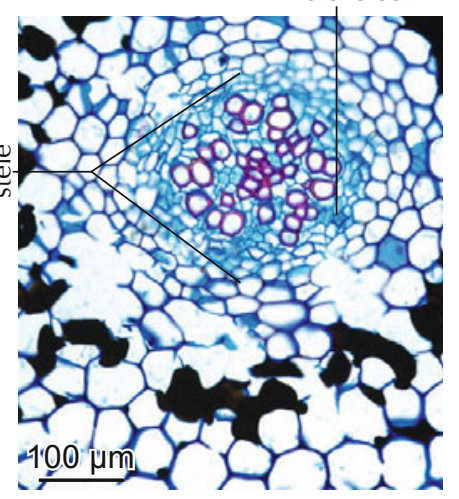

7.78 Irregular distribution of tracheids and sieve cells in the root of Psilotum nudum.

xylem vessels cambium phloem

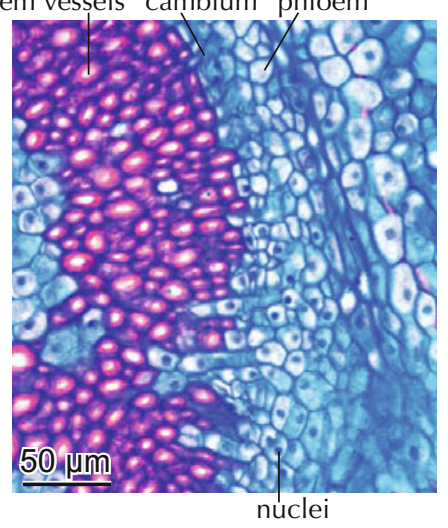

7.82 Cambium between xylem and phloem in Botrychium lunaria. the family. Absent are endodermis, fibers and parenchyma cells within the xylem.

Stems of Botrychium lunaria are anatomically closer to dicotyledons rather than to lycopods. Characteristic is a central strand of xylem and phloem (siphonostele) with a cambium in the upper part of the plant. It centripetally produces a xylem, which consists of vessels with distinct perforation plates with large pits and rays. Fibers and axial parenchyma cells are absent. The central strand in the root is a closed concentric vascular bundle consisting of tracheids with bordered pits.
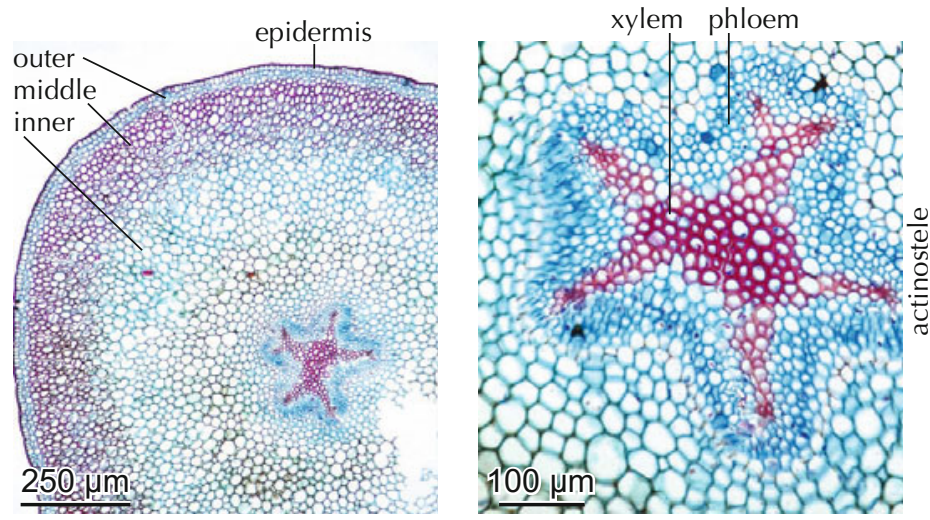

7.75 Central cylinder surrounded

sieve cell by a large cortex and an epidermis in Psilotum nudum.

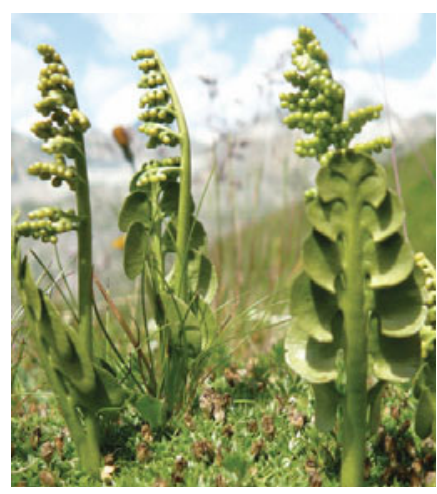

7.79 Botrychium lunaria.

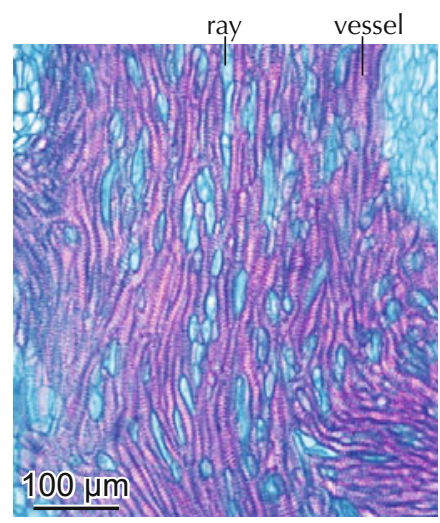

7.83 Lignified vessels and unlignified rays in Botrychium lunaria.
7.76 Star-like arrangement of vessels (actinostele) in Psilotum nudum.

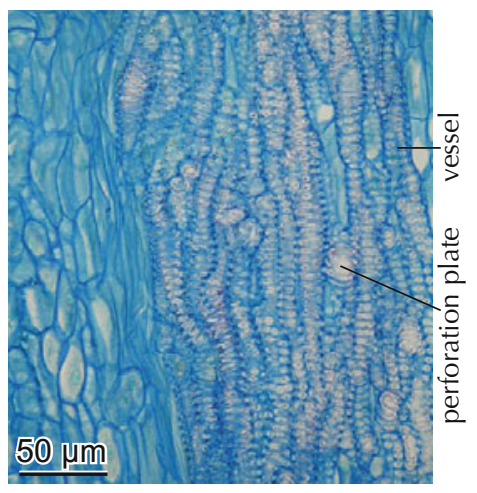

7.80 Vessels with perforation plates

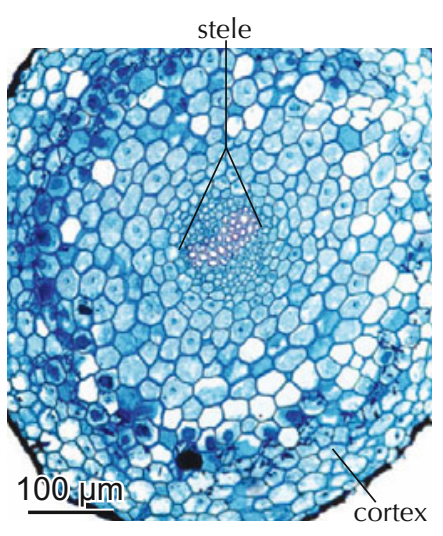

7.84 Root of Botrychium lunaria with a protostele. in Botrychium lunaria. 


\subsubsection{Horsetails}

The genus Equisetum, with approximately 20 species, is the only living genus within the Equisetophytina. Horsetails are anatomically chimeric: tracheids/vessels in vascular bundles within the internodes indicate a relationship to ferns, those in the nodes to dicotyledons (intercalary meristem) and the roots to the rhizomes of monocotyledons.

Vertical shoots with reduced leafs (sheaths) above nodes and long internodes are characteristic for all horsetails. Secondary growth is absent. Common for all species are intercalary meristems in the nodes, circular arranged vascular bundles (siphonostele) centripetal of the epidermis and a large cortex. The cortex consists of an epidermis, an outer part with thick-walled, often lignified fibers and inner, thin-walled part, with large, axially elongated schizogenous intercellulars (vallecular canals). The anatomy of the central strand is different in the internodes and nodes.

\section{Structure of the internodes}

In one group of species the central strand is bordered by an endodermis, e.g. in Equisteum arvense or E. sylvaticum. In the other group, the single vascular bundles are directly surrounded by the endodermis, e.g. in E. limosum or E. hiemale. The xylem of the vascular bundles of all species is reduced to a few isolated thick-walled tracheids or vessels. Their walls consist of lignified rings or of wide-spaced scalariform pits. Perforations plates and scalariform pits with very large apertures are hard to differentiate. The term tracheid/vessel is therefore used. Parenchyma cells surround the phloem. The sieve tubes have horizontal sieve plates. Lateral plates are absent. Within the area of the xylem is a large opening, the carinal canal, which occasionally contains tyloses.
Macroscopic aspect

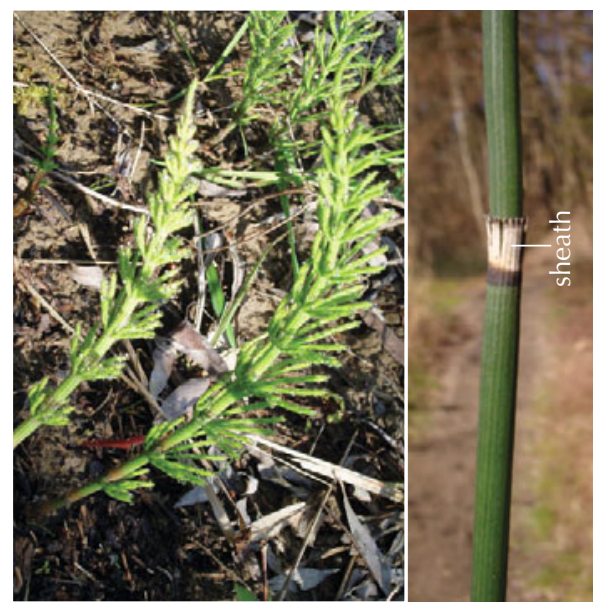

7.85 Equisetum arvense (left) and node of Equisetum hiemale (right).

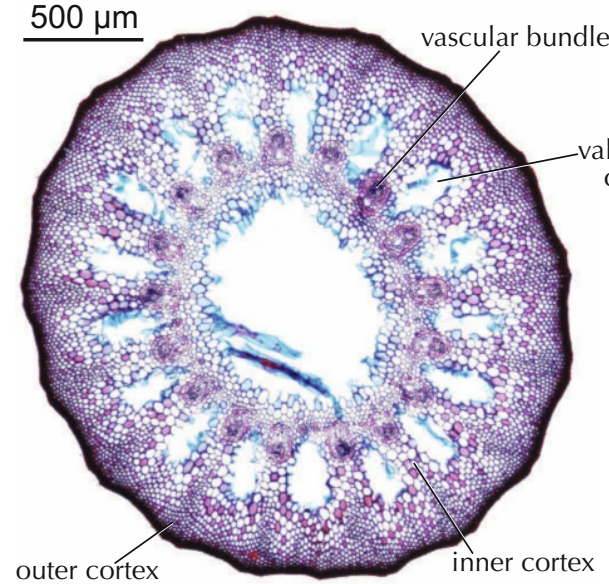

7.86 Equisetum arvense with dense outer cortex, small vallecular canals, circular arranged vascular bundles and a hollow center.

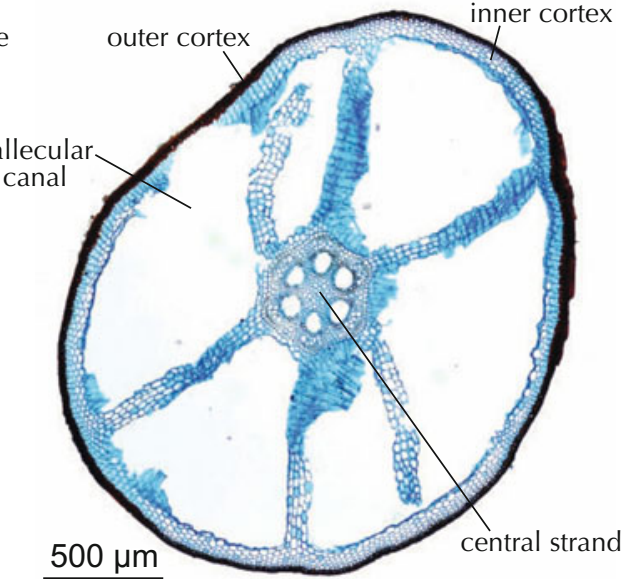

7.87 Equisetum palustre with very large vallecular canals (aerenchyma) in the cortex and a small central strand.

\section{Vascular bundles in internodes}

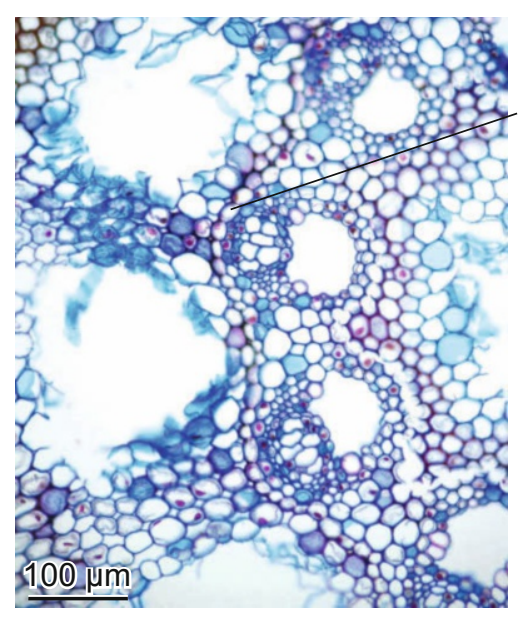

7.88 An endodermis separates the central strand and the cortex in Equisetum sylvaticum.

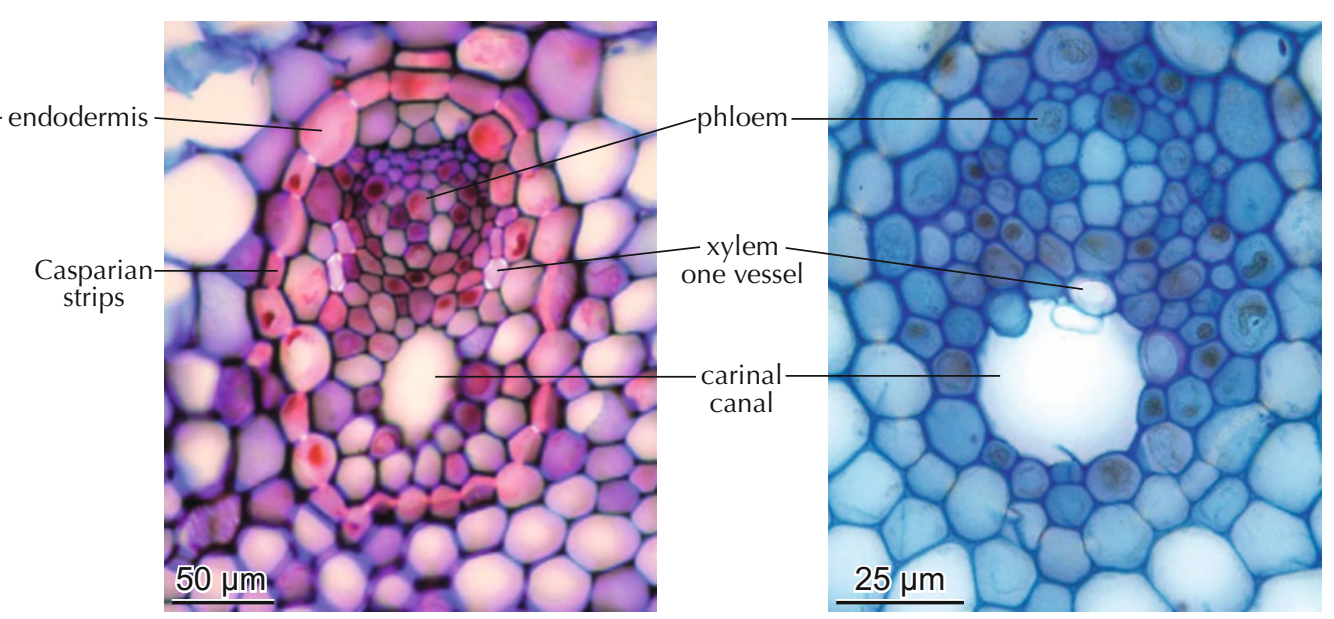

7.89 An endodermis separates a single closed collateral vascular bundle from surrounding parenchyma in Equisetum hiemale.
7.90 A single vascular bundle without distinct endodermis in Equisetum limosum. 


\section{Structure of the nodes}

The origin of lateral shoots is in the nodes. Collateral, probably open vascular bundles are arranged in a compact circular belt of xylem and phloem. The xylem of the bundles consists of tracheids/vessels with bordered pits. A layer of small parenchyma cells in the pith and horizontally oriented vessels and an intercalary meristem divide the nodes axially. There is a continuum between bordered pits in the internodes and scalariform pits in the nodes.

\section{Structure of the root}

A single concentric vascular bundle with a single vessel is surrounded by a cortex (Carlquist 2011).

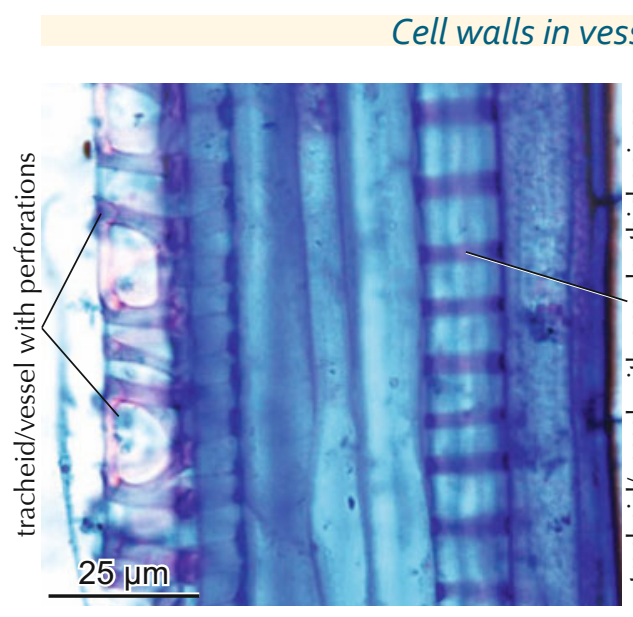

7.91 Vessel walls with widely spaced pit apertures or perforation plates and annular thickenings in Equisetum arvense.

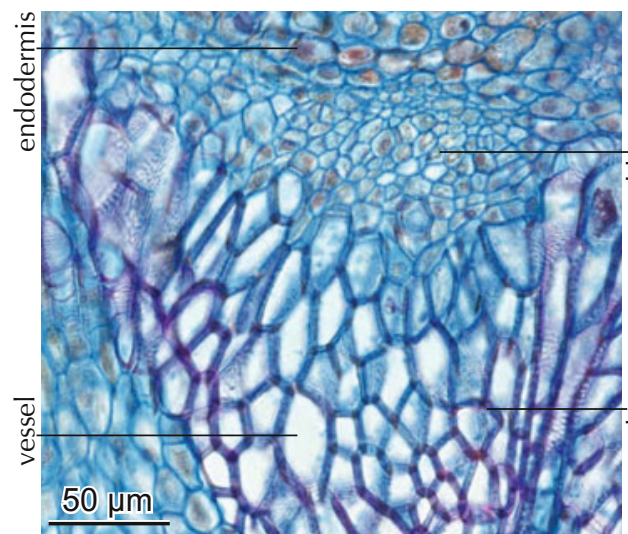

7.94 A single open? collateral vascular bundle with a xylem and phloem in Equisetum arvense.

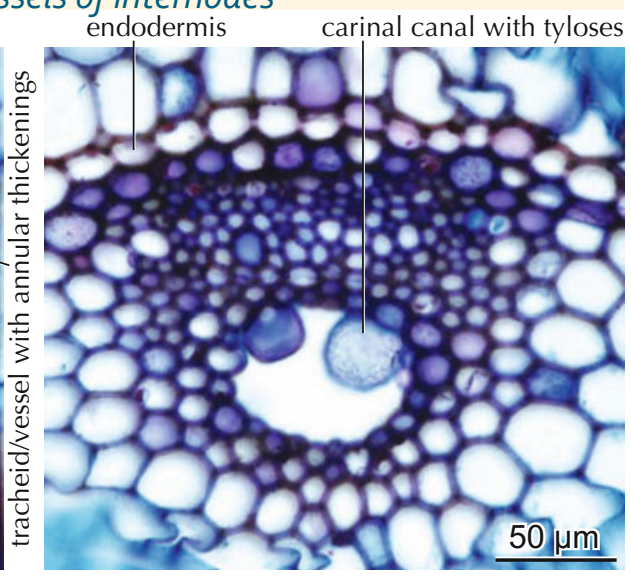

7.92 Tyloses in a carinal canal of a vascular bundle in Equisetum sylvaticum.

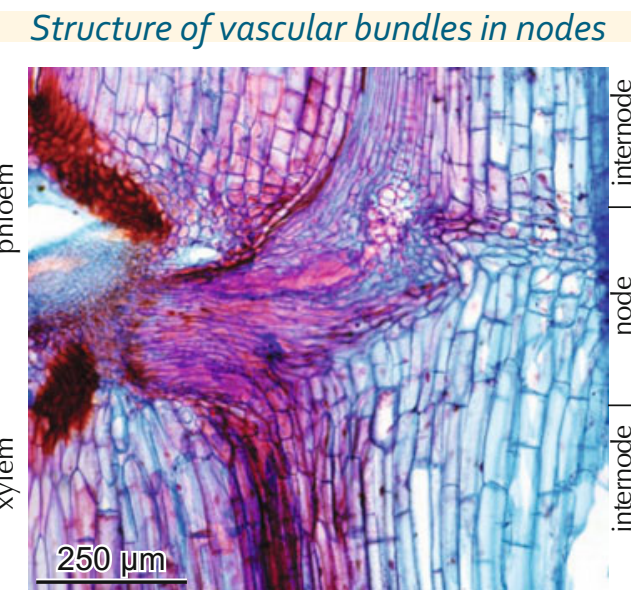

7.95 Node with a lateral branch in Equisetum arvense.

\section{Structure of nodes}

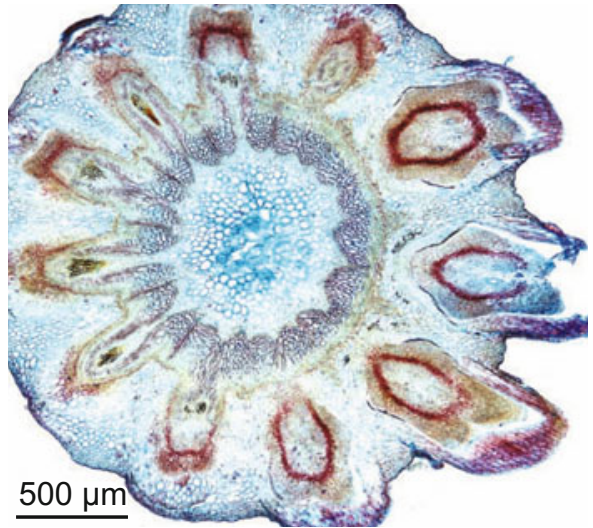

7.93 Central strand and lateral shoots of Equisetum arvense.

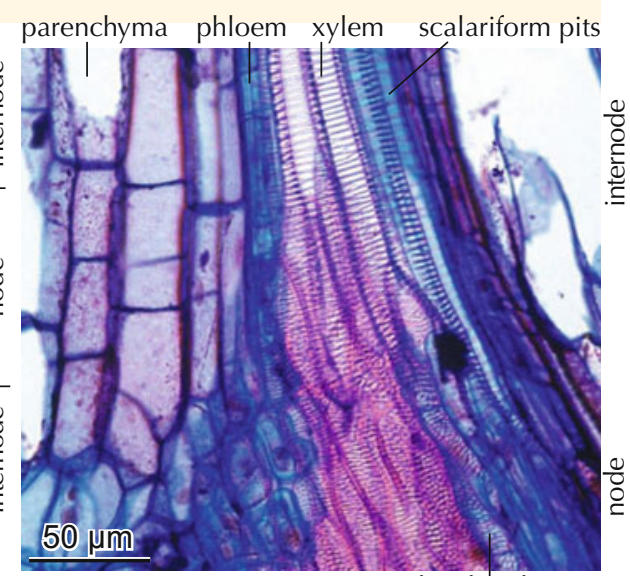

bordered pits 7.96 Vessel transition from an internode to a node in Equisetum arvense.
Structure of vessel walls in nodes

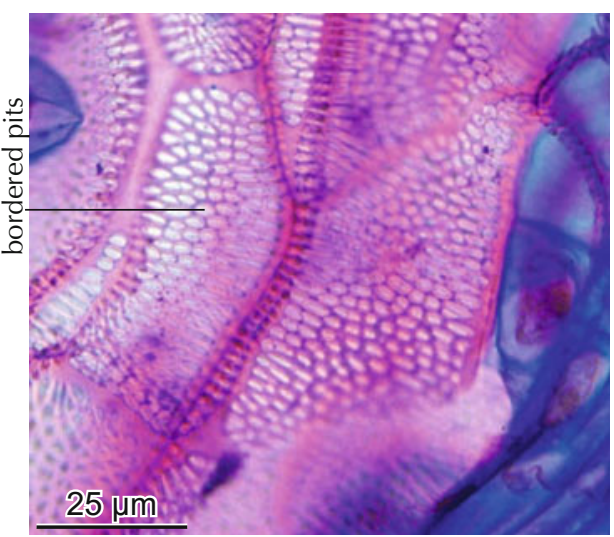

7.97 Bordered pits in vessels of a node of Equisetum arvense, longitudinal section.

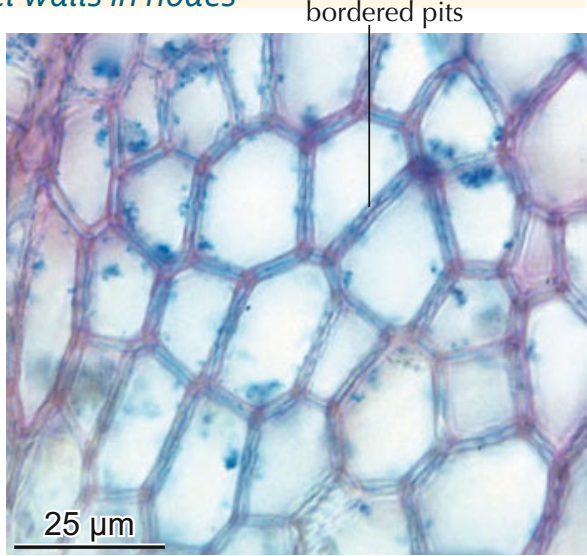

7.98 Bordered pits in vessels of a node of Equisetum arvense, cross section.
Structure of the root

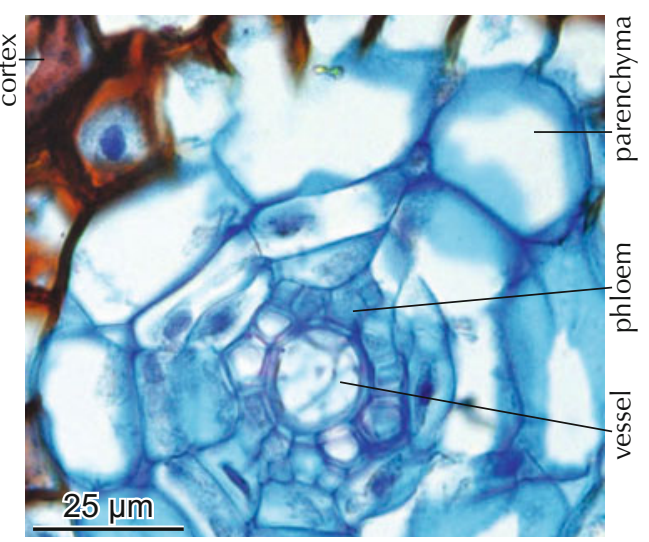

7.99 Concentric vascular bundle with a single vessel in Equisetum arvense. 


\subsubsection{Ferns}

The Filicophytina include approximately 9,000 species. Presented here are common anatomical traits of ferns. Tree ferns, hemicryptophytes and water ferns occur from the tropics to the arctic zone and grow on very dry to very moist sites. Ferns form petioles, stems, rootstocks and rhizomes. Secondary growth is absent. Vascular bundles are arranged solitary, or in irregular groups lateral of petioles; they are circular arranged in root stocks and stems, or they form bands. The arrangement of vascular bundles varies within the plant; it is different in rhizomes and in petioles.

Most ferns have closed amphiversal vascular bundles with a lignified xylem and solitary parenchyma cells in the center. The unlignified surrounding belt consists of sieve tubes, companion cells, groups of parenchyma cells and an endodermis. The form and the arrangement of the cell types vary. Closed collateral vascular bundles occur in hydrophytes.
A very thin-walled endodermis, often with Casparian strips, surrounds vascular bundles. The parenchyma cells which separate the cortex from the vascular bundle are mostly centripetally very thick-walled and lignified. The majority of tracheids in all observed species have scalariform pits, however, transitions of scalariform pits to bordered pits occur frequently. Perforation plates on distal ends of tracheids occur in a few species. These types are real vessels. In a few species sieve fields occur, as far as could be observed, only on lateral walls.

The structure of the cortex of petioles, rhizomes and stems greatly varies. In all cases one or more layers of thick-walled parenchyma cells surround a layer of more or less thin-walled parenchyma. The thick-walled cells can be either parenchyma cells or fiber-like cells with slightly bordered pits. Thin-walled parenchyma cells contain starch. Specialized cells or ducts of some species produce slime. See also White 1963.

\section{Growth forms of ferns}

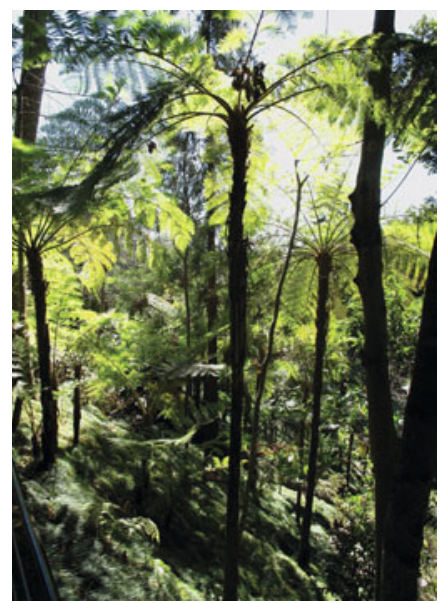

7.100 Tree fern Cyathea cooperi.

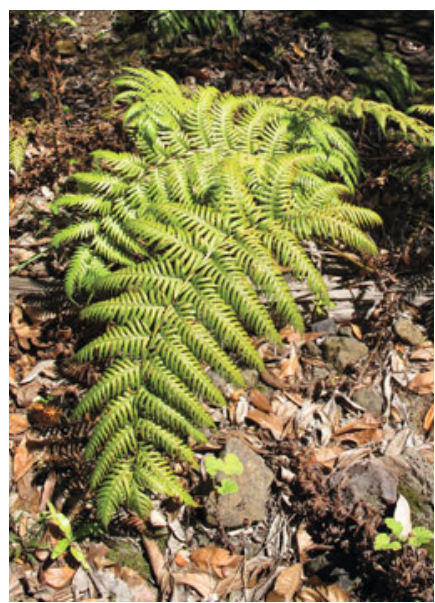

7.101 Large hemicryptopyte Woodwardia radicans.

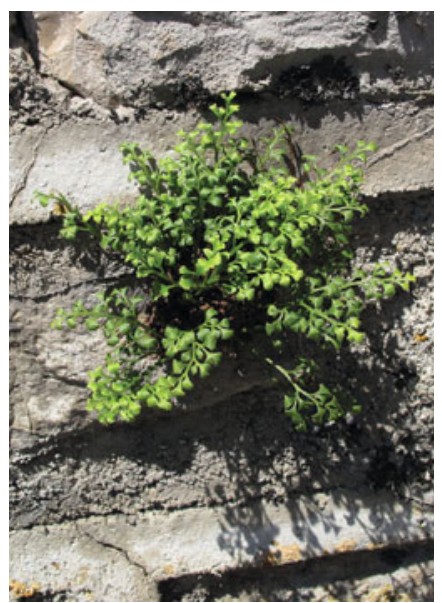

7.102 Small hemicryptophyte Asplenium ruta-muraria.

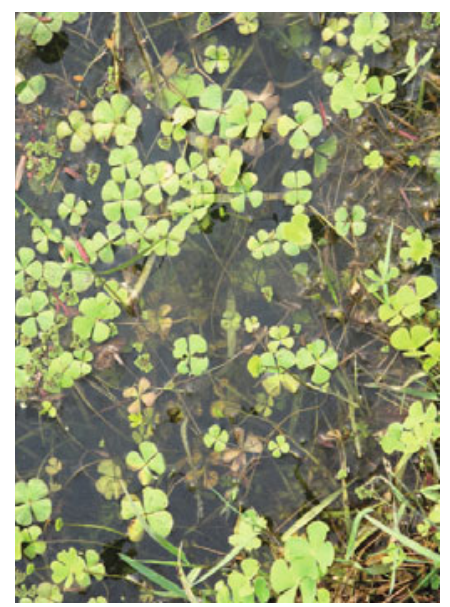

7.103 Hydrophyte Marsilea quadrifolia.

\section{Stems, root stocks and rhizomes}

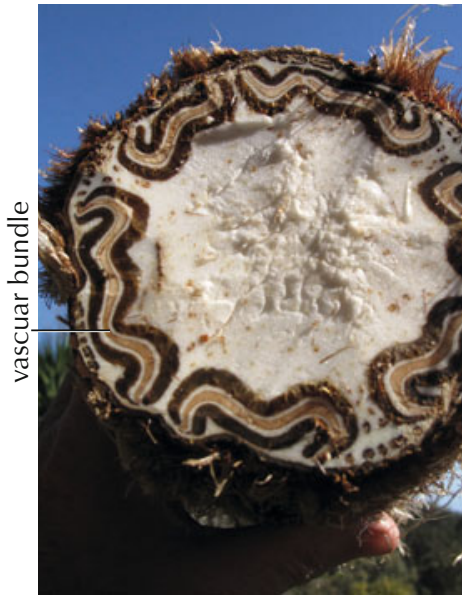

7.104 Stem of the tree fern Cyathea cooperi.

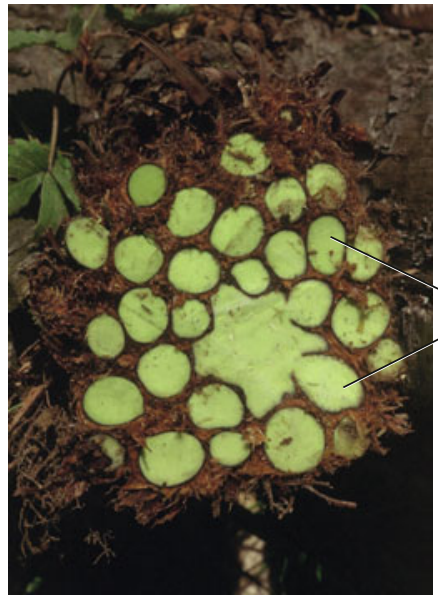

7.105 Rootstock with leaf bases of the hemicryptophyte Dryopteris filix-mas

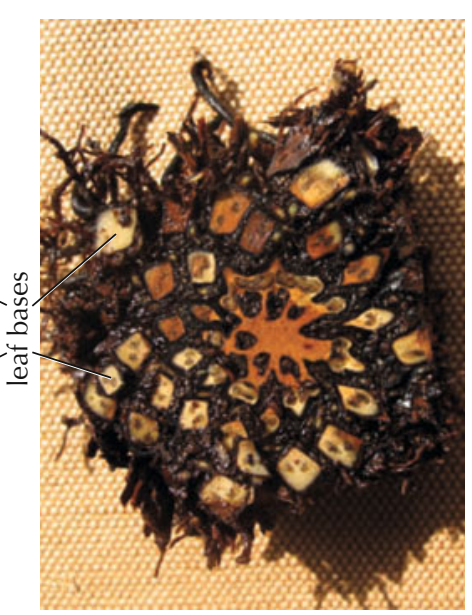

7.106 Rootstock with leaf bases of the hemicryptophyte Matteuccia struthiopteris.

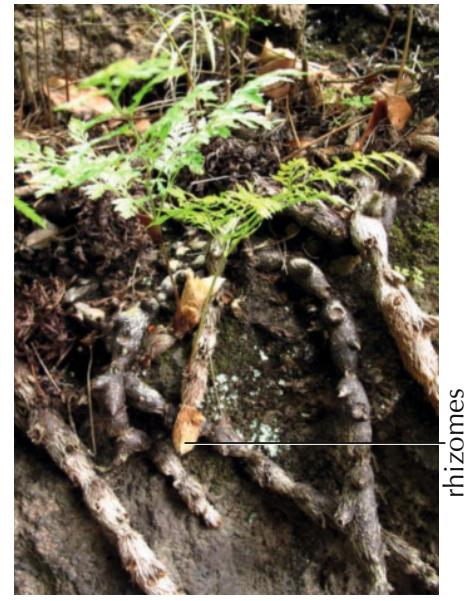

7.107 Rhizomes of Davallia canariensis. 


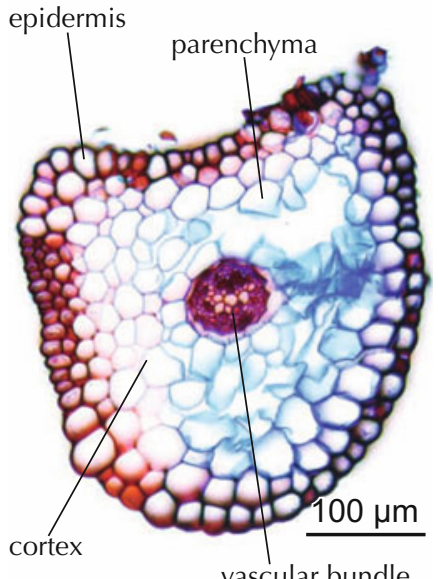

7.108 Solitary in the center of the petiole of an annual stem of Hymenophyllum tunbrigense. Protostele.

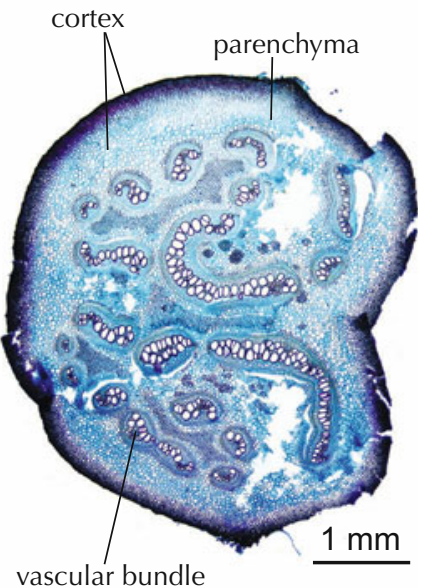

7.109 Irregularly distributed in the annual stem of Pteridium aquilinum. Polystele.

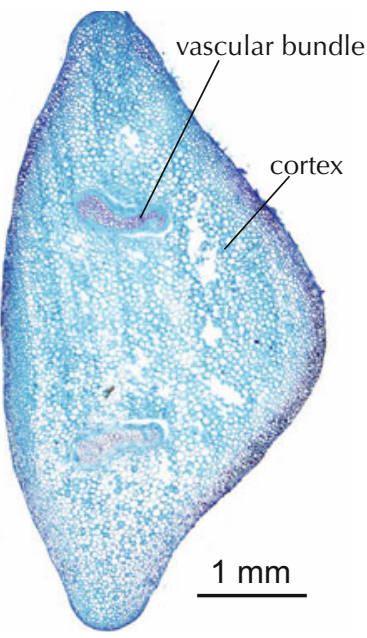

7.110 Lateral in a petiole of Athyrium filix-femina. Polystele.

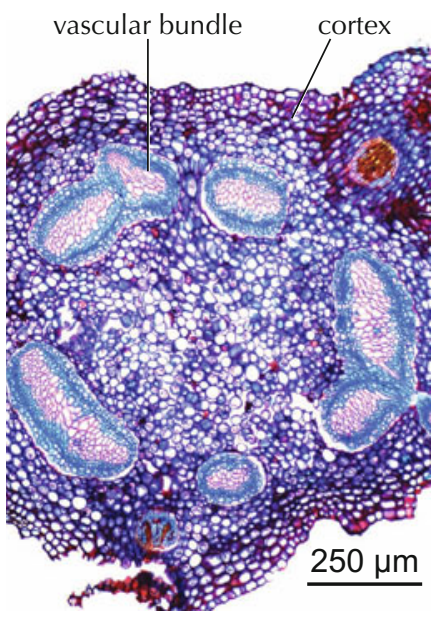

7.111 Circular in the rhizome of Asplenium septentrionale. Siphonostele.

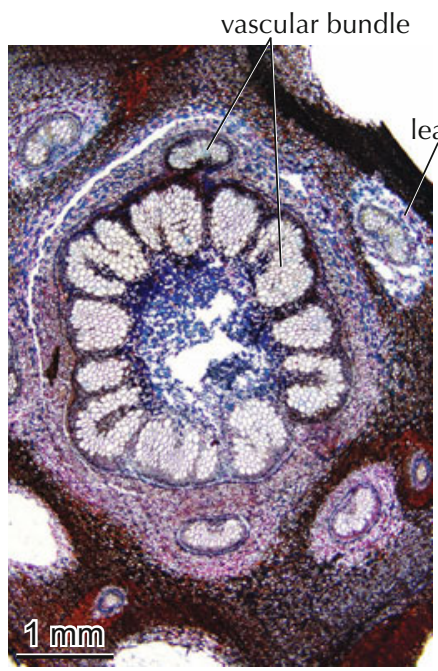

7.112 Circular in the root stock of Osmunda regalis. Siphonostele.

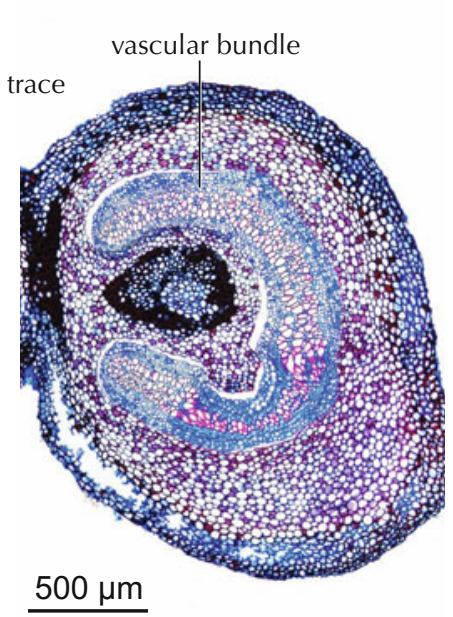

7.113 Arc-like in the rhizome of Cryptogramma crispa. Siphonostele.

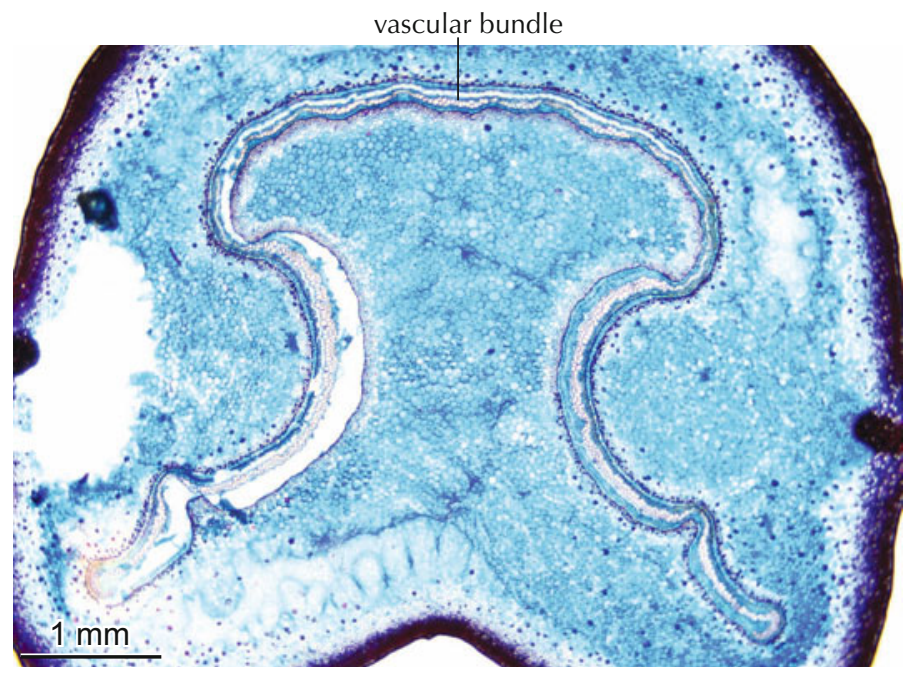

7.114 Arc-like in the petiole of Culcita macrocarpa. Siphonostele.
Internal variation of vascular bundle arrangement

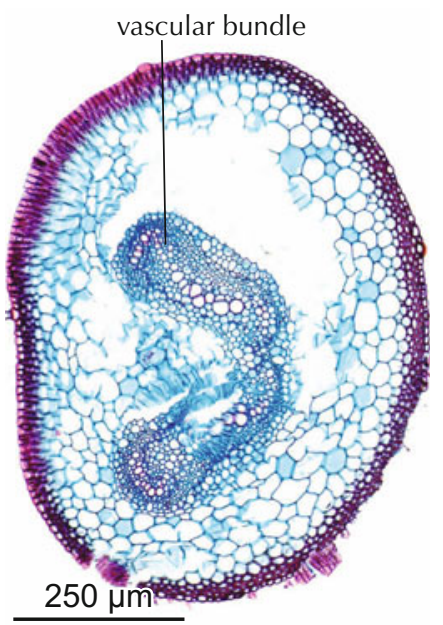

7.115 Two bundles in the petiole of Gymnocarpium robertianum. Polystele.

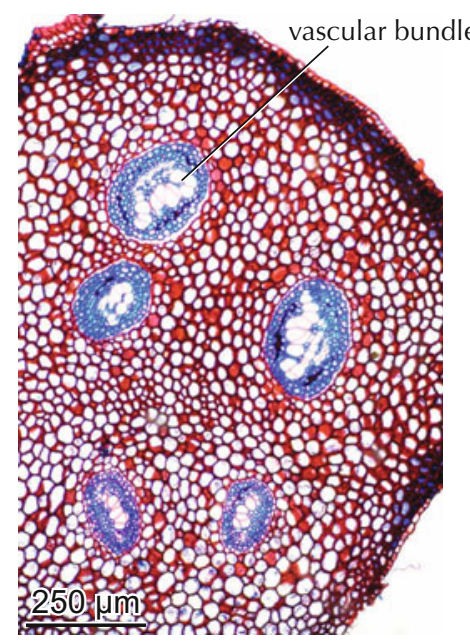

7.116 Round bundles, circular arranged in the root stock of Gymnocarpium robertianum. Siphonostele.

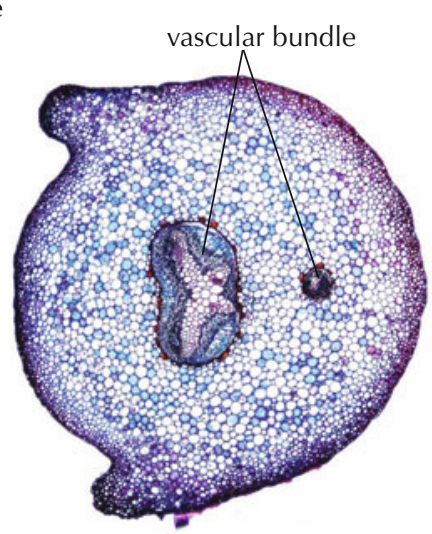

$500 \mu \mathrm{m}$

7.117 A large and a small bundle in a petiole of Polypodium vulgare.

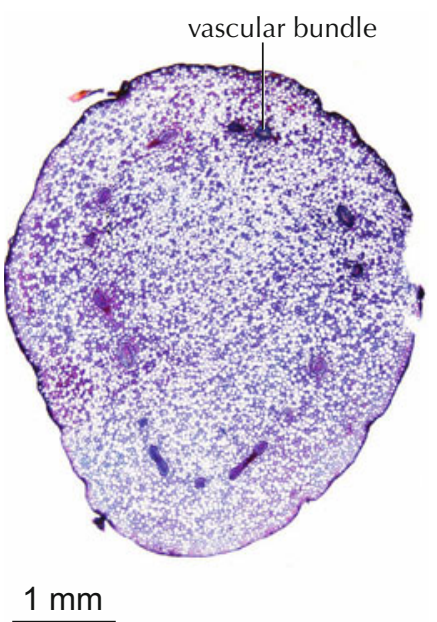

7.118 Different forms of bundles, circular arranged in the root stock of Polypodium vulgare. Siphonostele. 


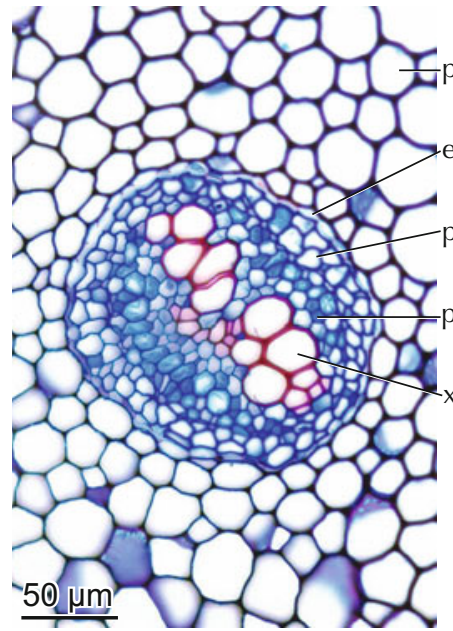

7.119 Laterally elongated xylem in a round vascular bundle of Gymnocarpium robertianum.

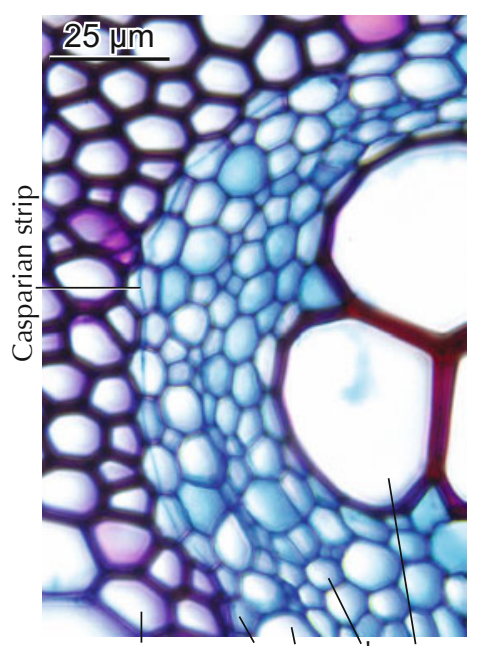

7.123 Endodermis with Casparian strips in Cyathea cooperi.

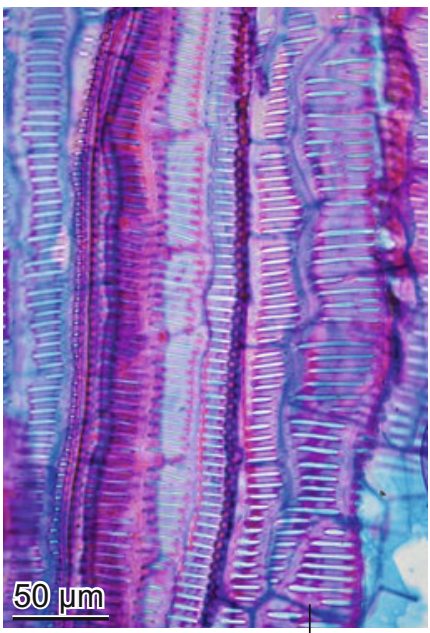

7.127 Scalariform pits in Cyathea cooperi.

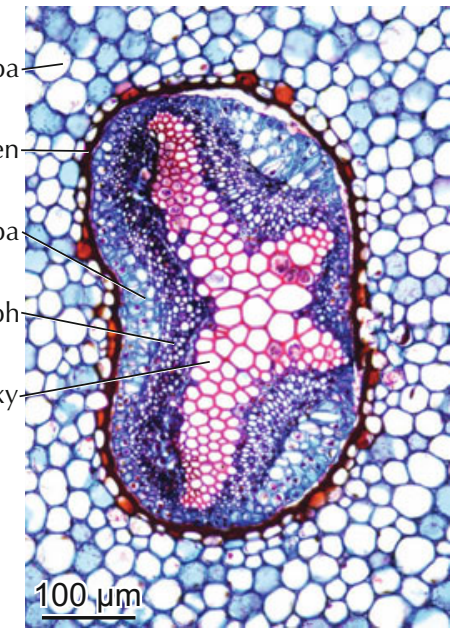

7.120 Eagle-shaped xylem in rhizome of Polypodium vulgare.

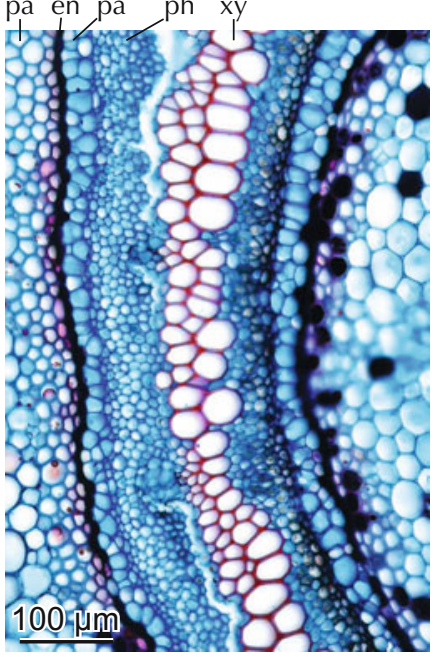

Endodermis of vascular bundles pericycle

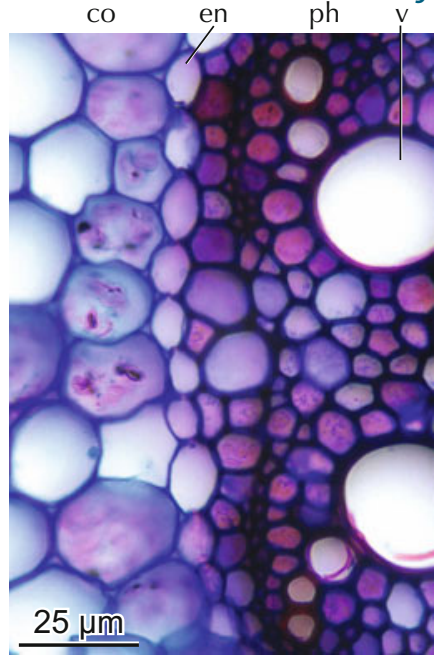

7.124 Endodermis without distinct Casparian strips in Marsilea quadrifolia.

Wall structure of tracheids

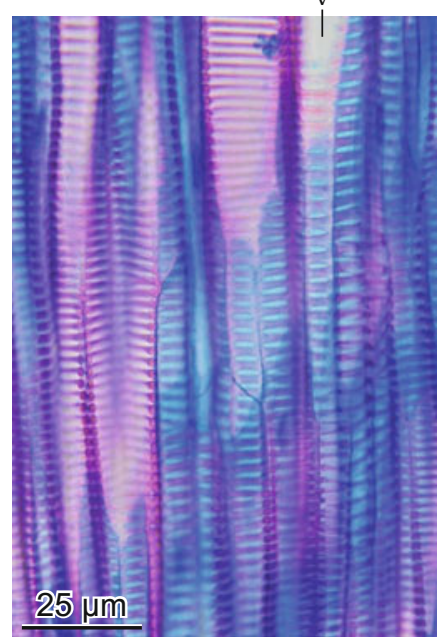

7.128 Scalariform pits in Blechnum spicant.

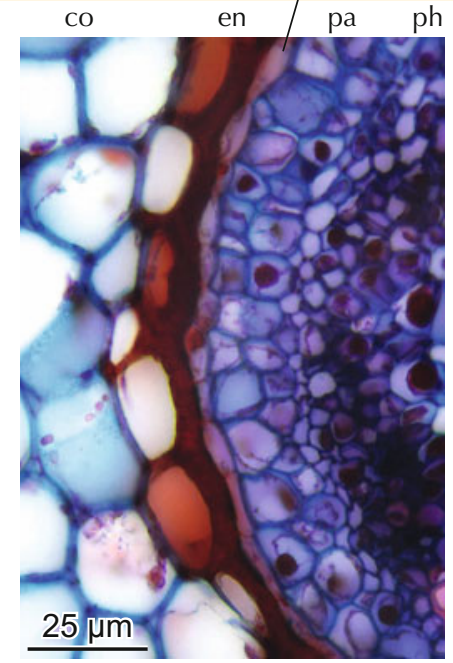

7.125 Thin-walled pericycle and thick-walled endodermis separate central cylinder and cortex in Polypodium vulgare.

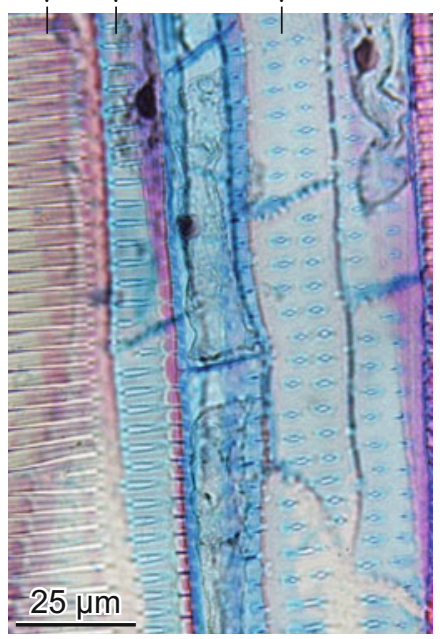

7.129 Scalariform and bordered round pits in Lygodium sp.

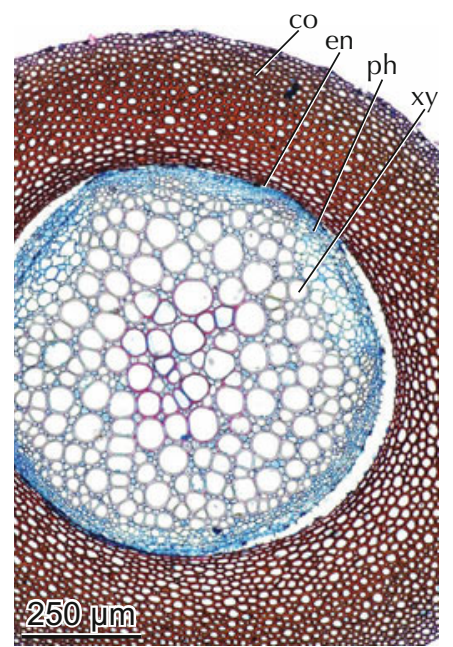

7.122 Round xylem/phloem strand in the stem of the liana Lygodium sp.

7.126 Thin-walled endodermis between a lignified cortex and an unlignified parenchyma tissue in Lygodium sp.

Wall structure of sieve elements

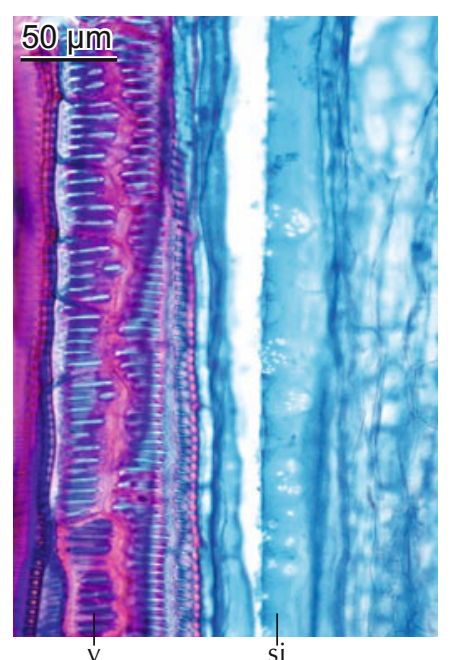

7.130 Sieve fields on lateral walls in Cyathea cooperi. 


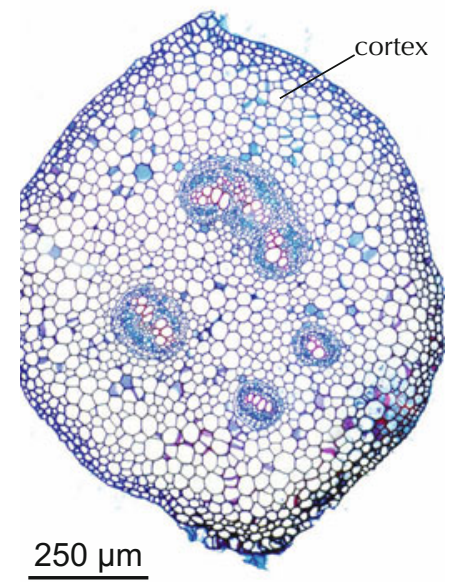

7.131 Thin-walled parenchyma cells are surrounded by an epidermis in Gymnocarpium robertianum.

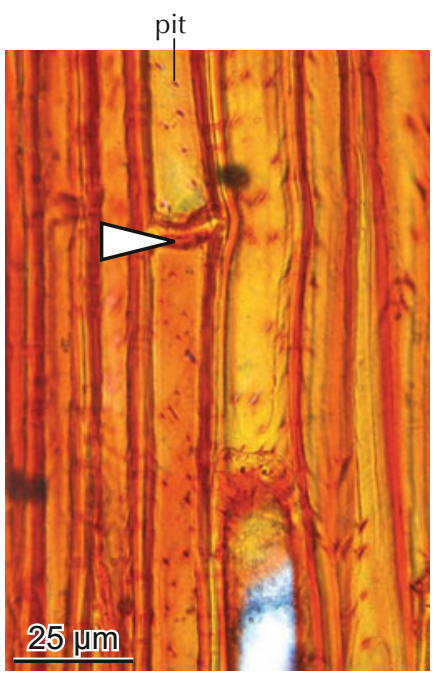

7.135 Parenchyma cells with horizontal walls and slightly bordered pits in Lygodium sp.

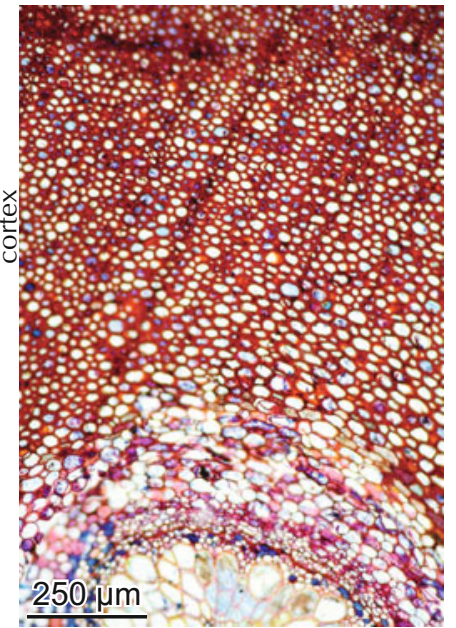

7.132 A layer of thick-walled parenchyma cells surrounds the vascular bundles in Osmunda regalis.

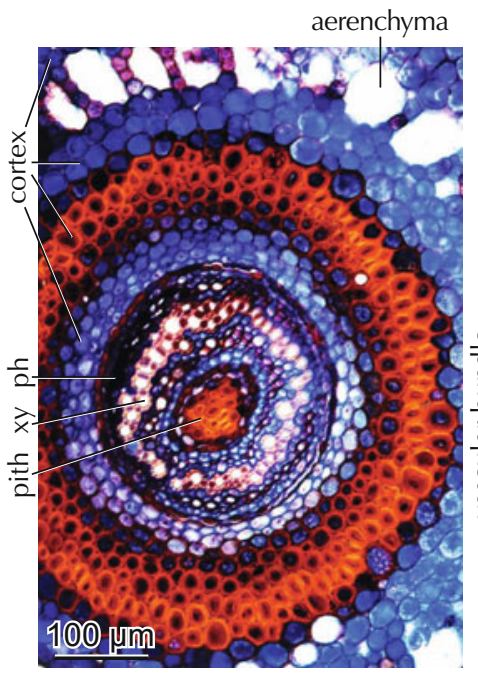

7.136 Multilayered cortex in the rhizome of Marsilea strigosa.

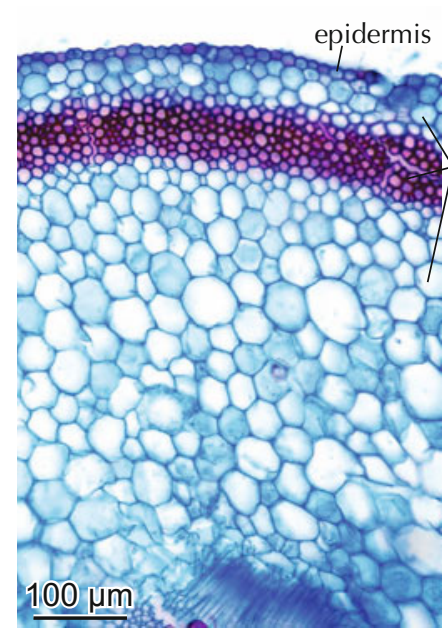

7.133 A layer of thick- and thinwalled cells occurs outside of a large, thin-walled parenchymatic zone in Marattia fraxinea.

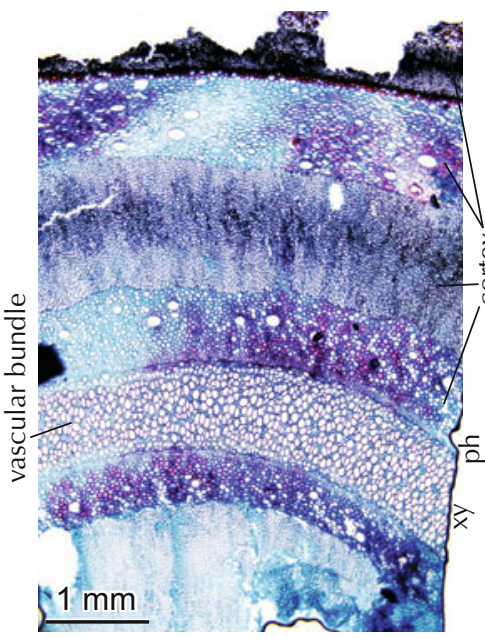

7.137 Multilayered cortex in the stem of Cyathea cooperi.

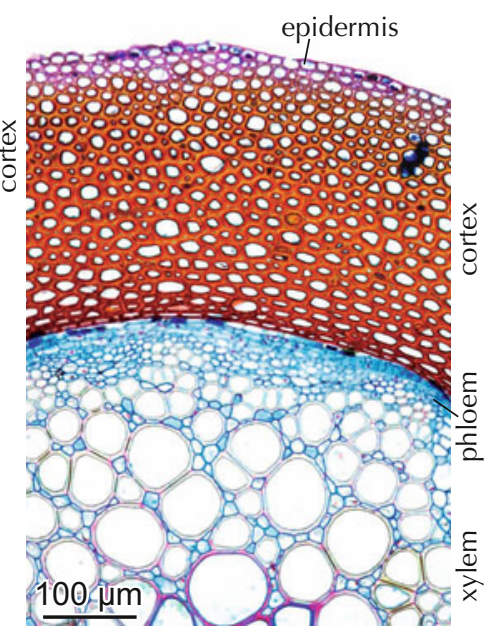

7.134 A dense belt of thick-walled cells surrounds the central xylem/ phloem strand in Lygodium sp.

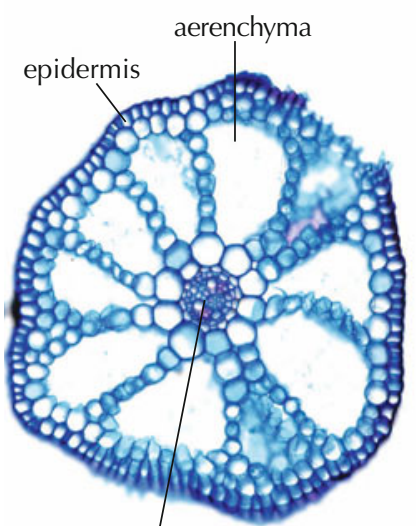

vascular bundle

$100 \mu \mathrm{m}$

7.138 Cortex with large aerenchymatic spaces of Pilularia globulifera.
Content of cortex cells

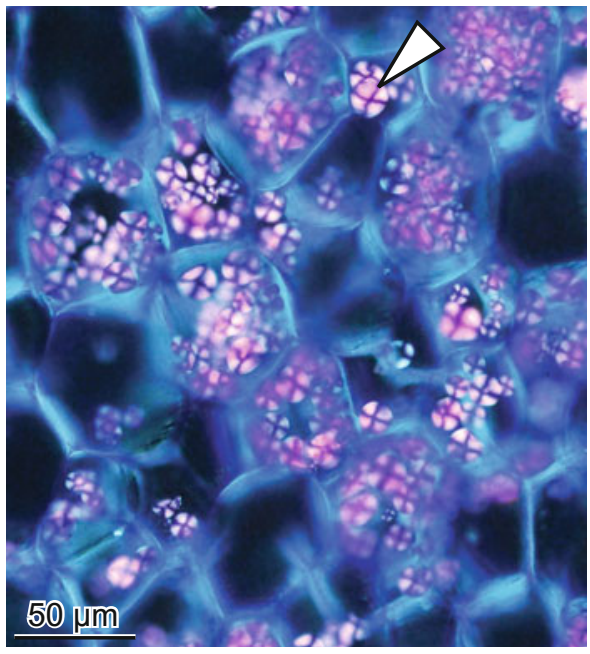

7.139 Starch in thin-walled parenchyma cells in Culcita macrocarpa, polarized light.

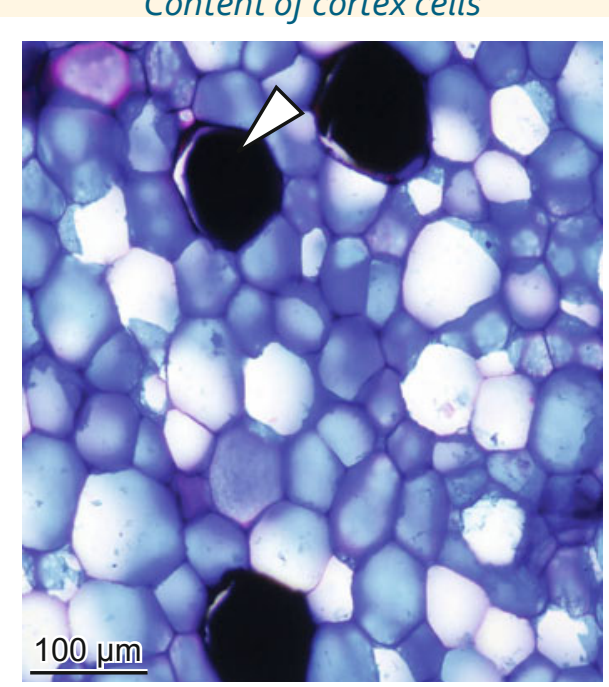

7.140 Dark-stained substances in parenchyma cells in Marattia fraxinea. duct

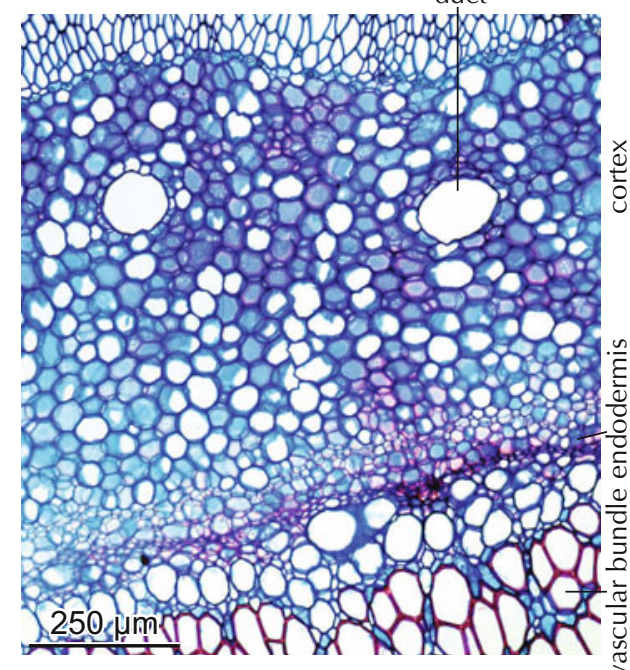

7.141 Slime-conducting ducts in parenchyma cells of Cyathea cooperi. 


\subsection{Seed plants}

\subsubsection{Palm ferns}

Within the Cycadopsida, the familes Cycadaceae and Zamiaceae exist worldwide today, with ten genera and approximately 90 species. Most species occur in the tropics. The following presentation is primarily based on the collection of Greguss 1968.

Secondary growth is characteristic for all palm ferns. The presence of circular arranged tracheids is a common feature. Within the Cycadopsida, two radial growth types occur: one forms a simple siphonostele containing isolated vascular bundles or a closed xylem/phloem ring, the other has successive cambia, which form single vascular bundles or xylem/phloem rings. Collateral vascular bundles occur in petioles. The xylem is composed of radially arranged roundish tracheids. Annual rings have not been observed. Tracheids have scalariform or bordered pits with slit-like apertures. Pits are arranged in one or more axial rows. Rarely, tracheids with ephedroid perforation plates (per definition vessels) occur. Rays are homogenous and composed of thin-walled parenchyma cells, arranged in one to several rows. The phloem contains fibers and sieve elements with lateral sieve fields. Companion cells were not observed.

Slime ducts occur in the pith and the cortex of some species. They are surrounded by small, unlignified excretion cells or, in a few species, also with lignified tracheid-like cells. Short, lignified cells, often with bordered pits, occur in the pith of some species (transfusion cells, terminus Greguss). Crystals in the form of druses, prisms or sand are frequent in parenchyma cells.

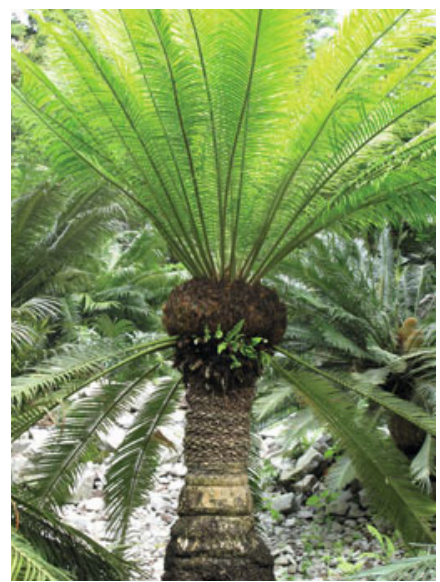

7.142 Cycas revoluta
Macroscopic aspect of palm ferns

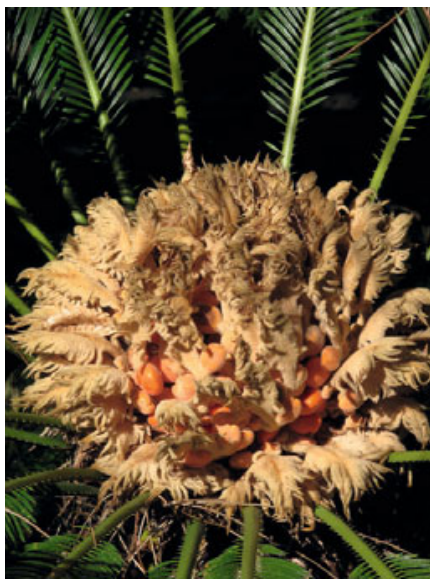

7.143 Cycas sp.

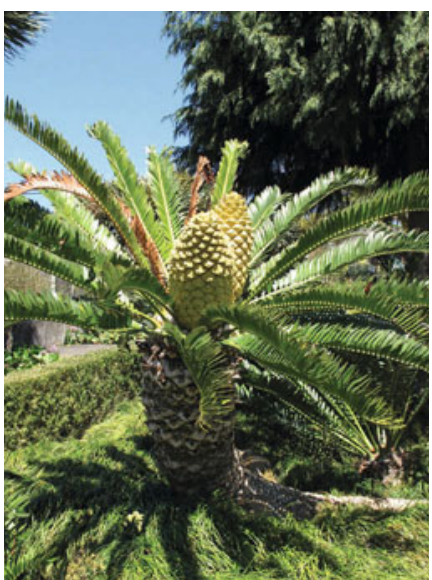

7.144 Encephalartos sp.
Pál Greguss's slide collection

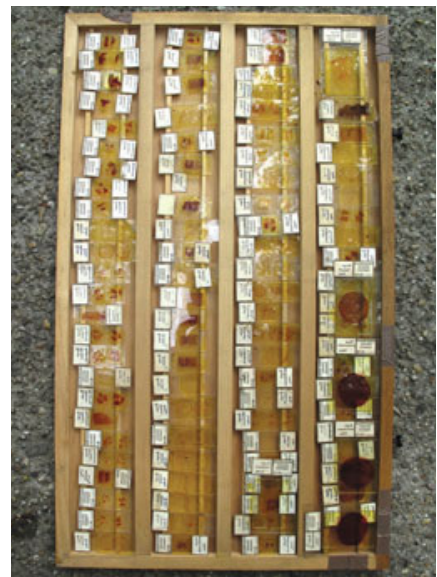

7.145 Cycad slide collection at the Hungarian Natural History Museum Budapest, Department of Botany.

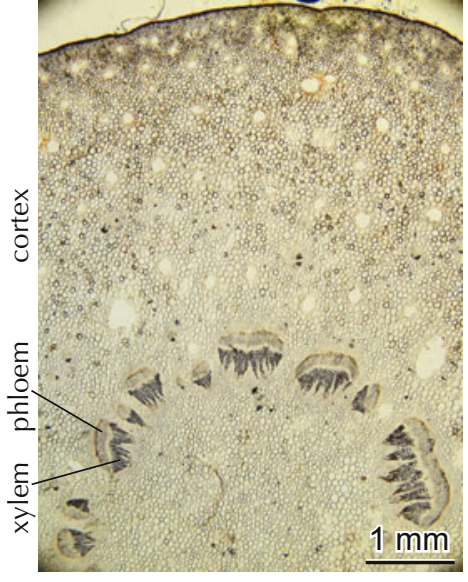

7.146 One cambium forms circular arranged vascular bundles in Ceratozamia mexicana. Eustele.

\section{Types of radial growth}

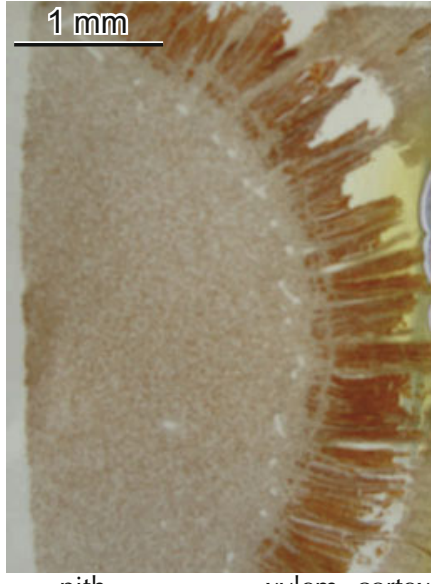

pith

7.147 One cambium forms a closed belt of xylem and phloem in Cycas sp. Eustele.

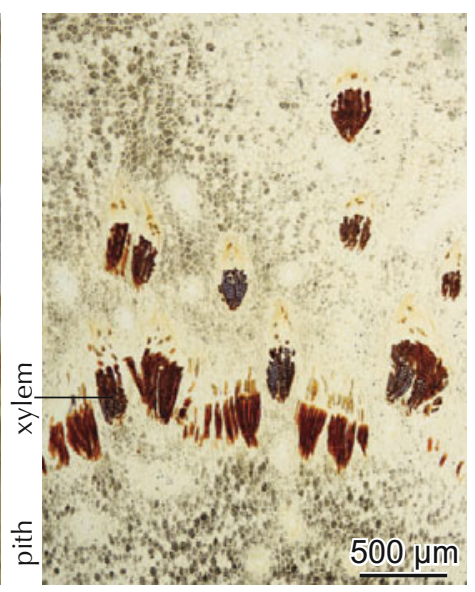

7.148 Successive cambia form single vascular bundles in Cycas sp.

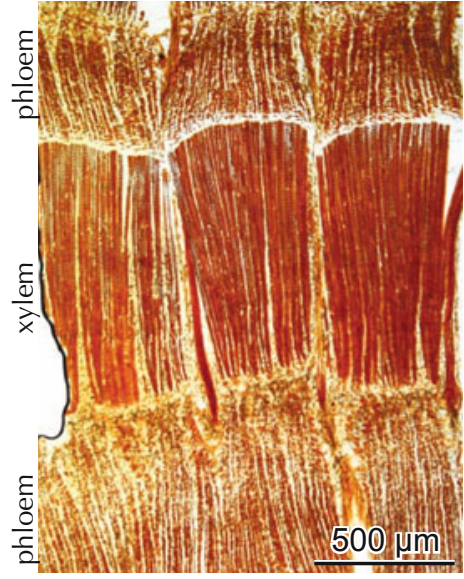

7.149 Successive cambia form several xylem/phloem rings in Macrozamia moorei. 
Collateral vascular bundles

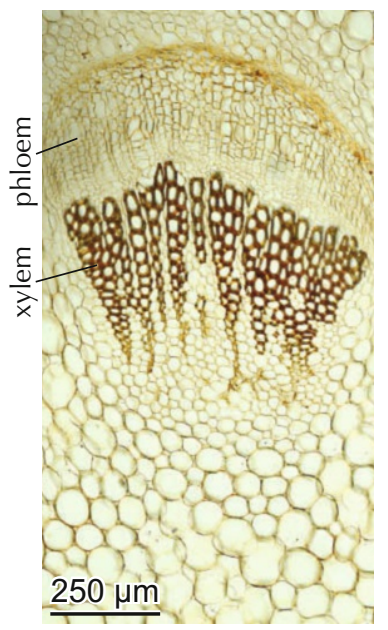

7.150 Stem of Ceratozamia mexicana.

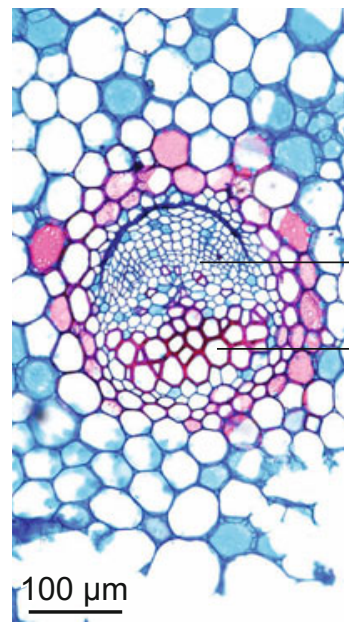

7.151 Petiole of Cycas revoluta.

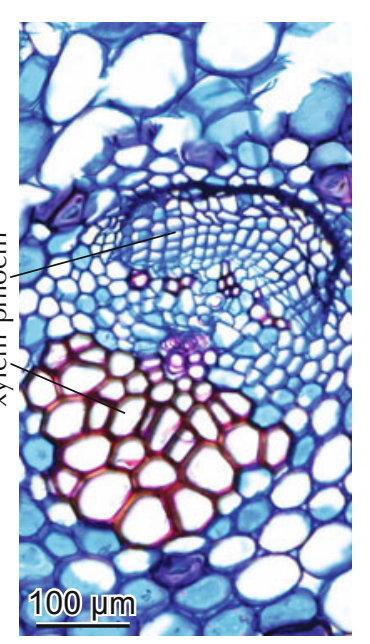

7.152 Petiole of Zamia pygmaea.

Xylem with tracheids

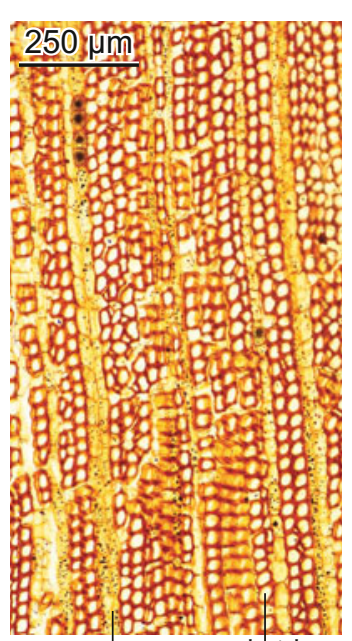

7.153 Roundish tracheids, strictly radially arranged, in Dioon spinulosum.

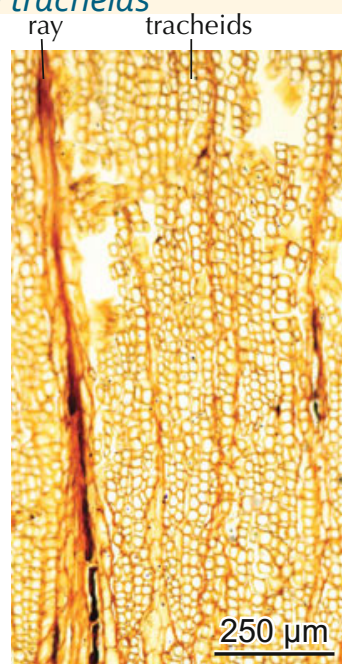

7.154 Roundish tracheids in Zamia skinneri.

Pitting of tracheids

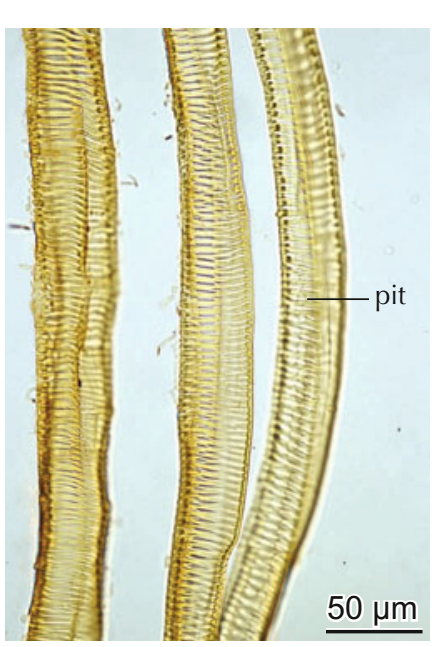

7.155 Scalariform pits in Zamia furfuracea.

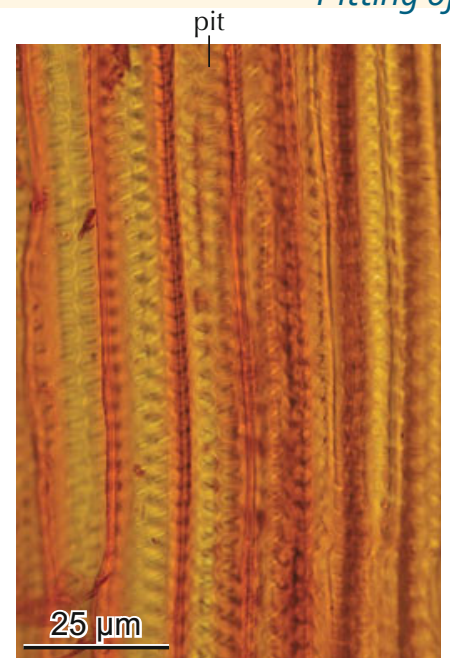

7.156 Bordered pits with slit-like apertures in Encephalartos hildebrandtii.

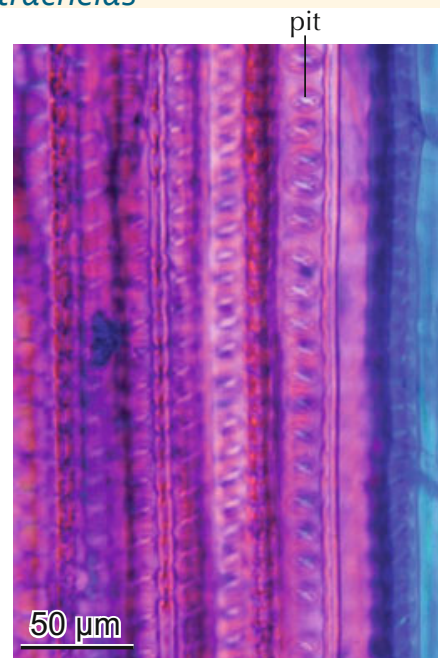

7.157 Bordered pits with slit-like apertures in Cycas revoluta.

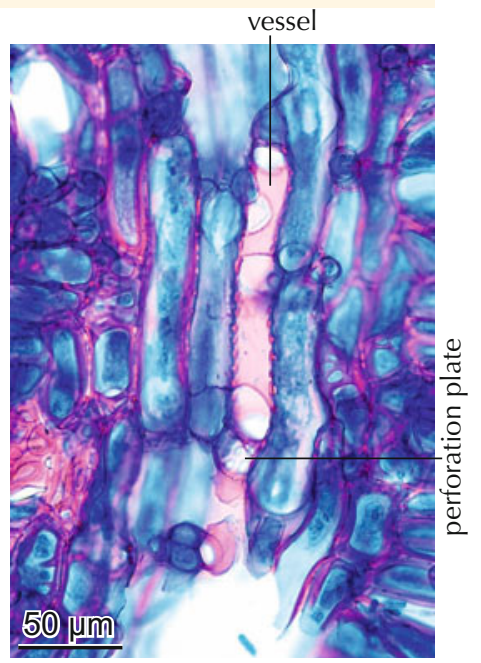

7.158 Vessels with ephedroid perforation plates in Zamia sp.

Width of rays

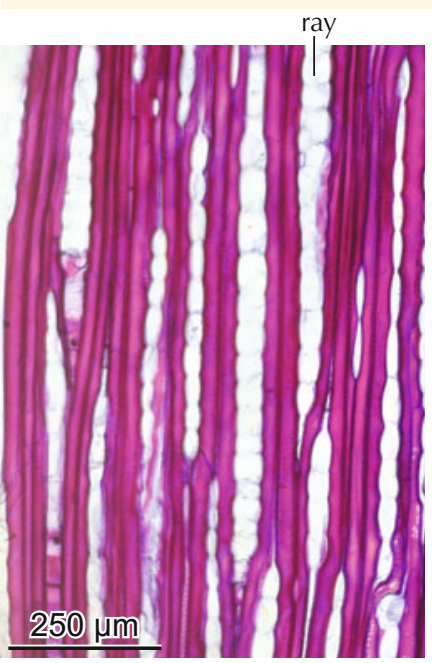

7.159 Uniseriate rays in Cycas media. ray ray

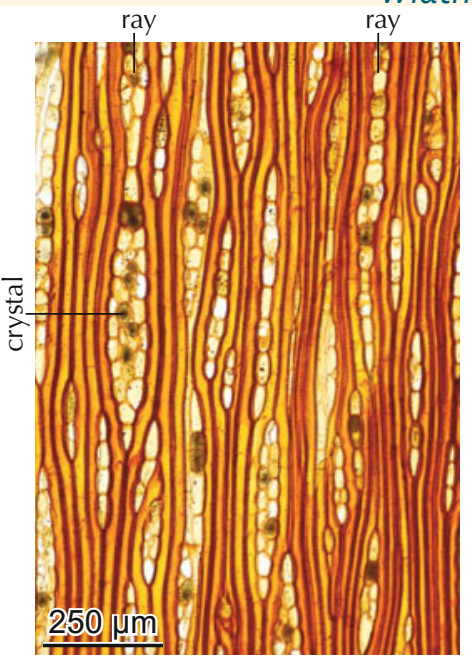

7.160 One- to triseriate, homogeneous rays in Dioon spinulosum.

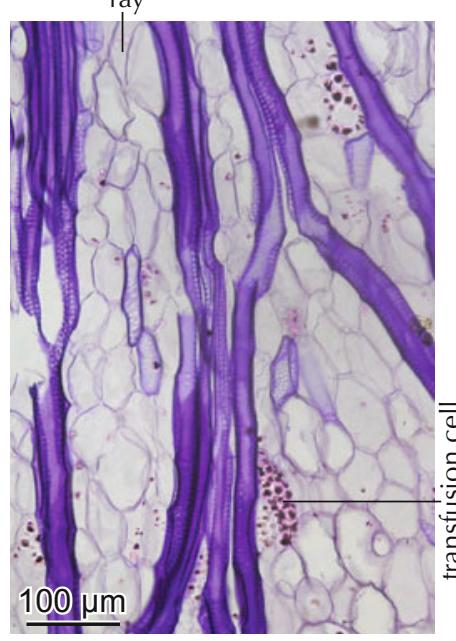

7.161 Multiseriate rays with thinwalled cells and a few transfusion cells in Macrozamia pauli-guilielmi.

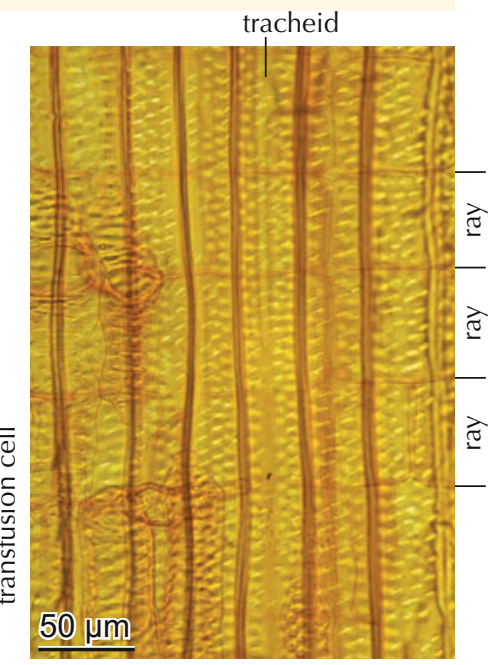

7.162 Ray with square, thin-walled cells, radial section of Encephalartos septentrionalis. 


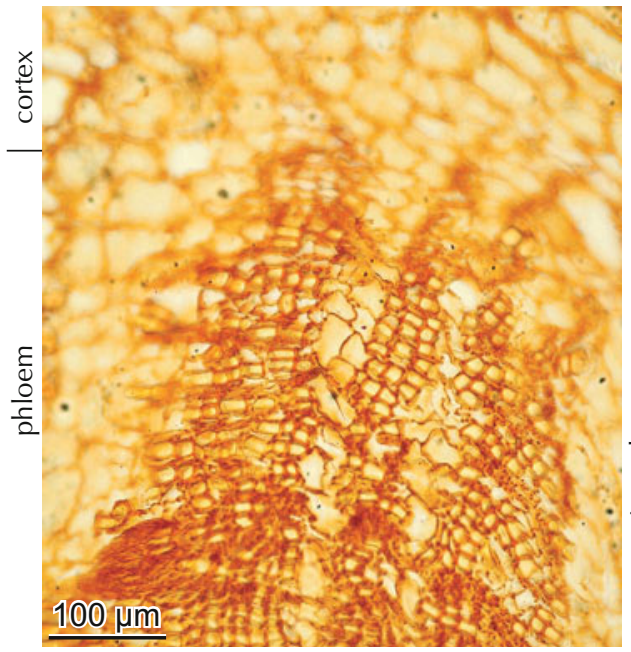

7.163 Collapsed sieve elements and square fibers in Zamia skinneri.

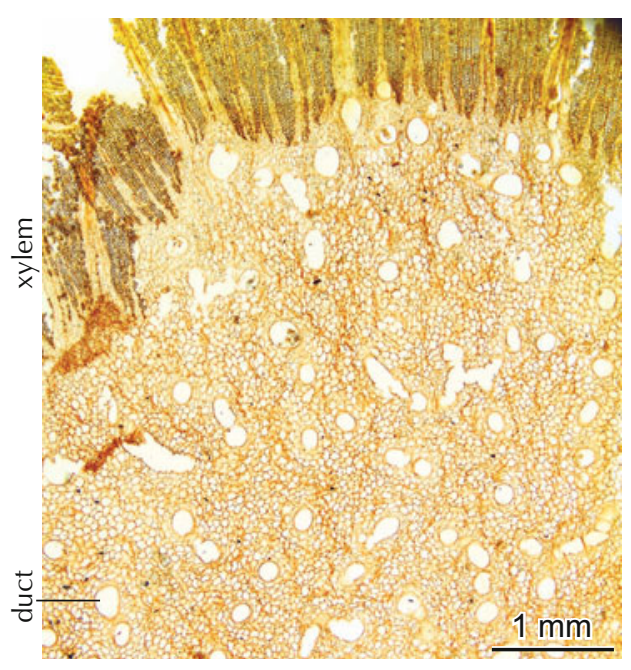

7.166 Ducts in the pith of Zamia skinneri.

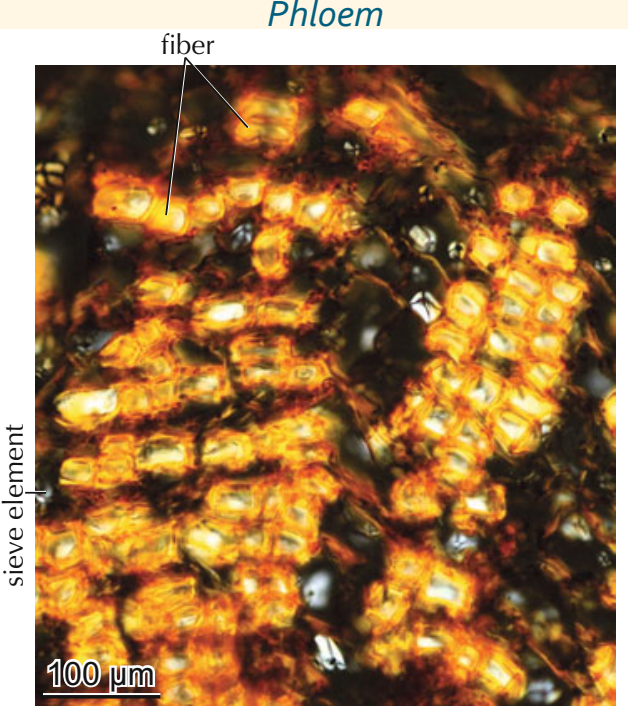

7.164 Distribution of fibers (yellow) and thinwalled sieve elements in Zamia skinneri.

Slime ducts

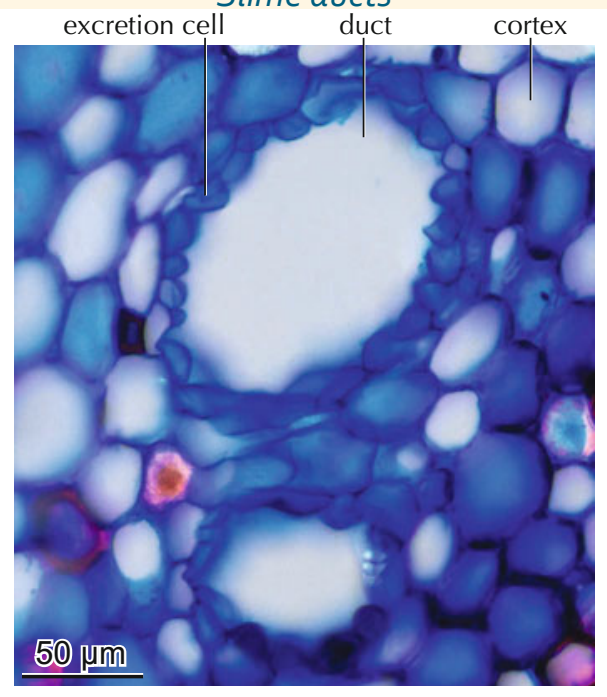

7.167 Ducts with small, unlignified excretion cells in Encephalartos hildebrandtii.

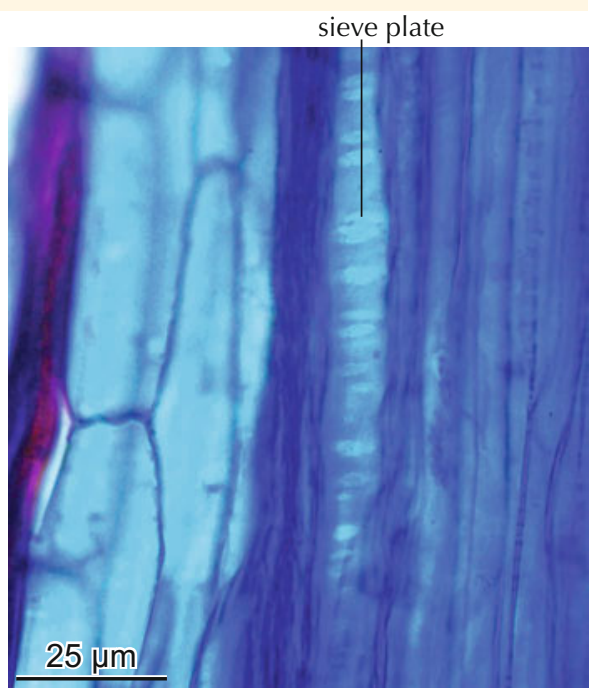

7.165 Sieve element with lateral sieve plates in Encephalartos hildebrandtii.

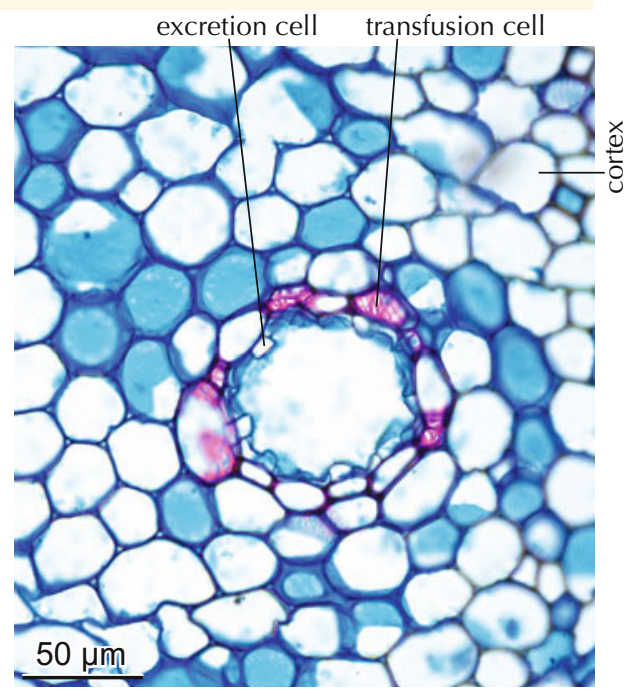

7.168 Ducts with small, unlignified excretion cells and lignified pitted cells in Dioon edule.
Isolated lignified cells in the pith (transfusion cells)

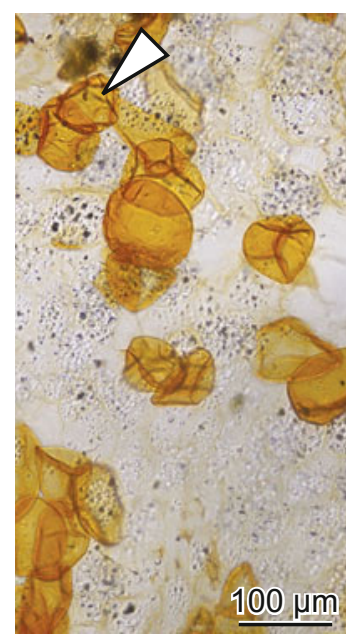

7.169 Cells with unstructured walls in Macrozamia moorei.

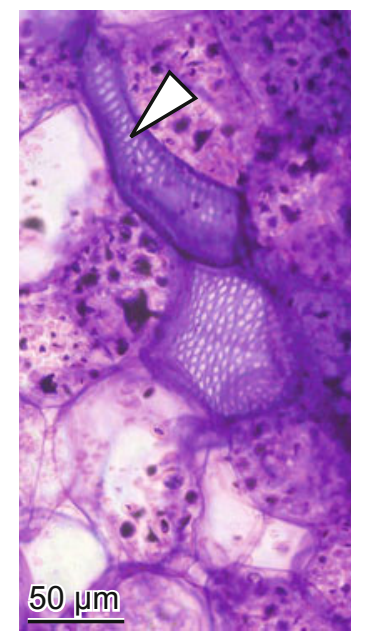

7.170 Cells with pitted walls in Macrozamia pauliguilielmi.

Crystals in parenchyma cells

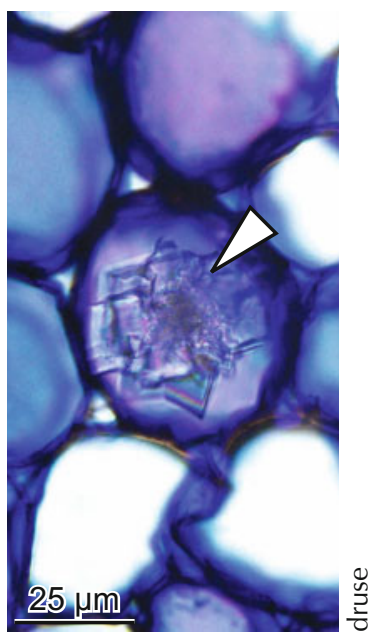

7.171 Druses in Zamia pyg maea.

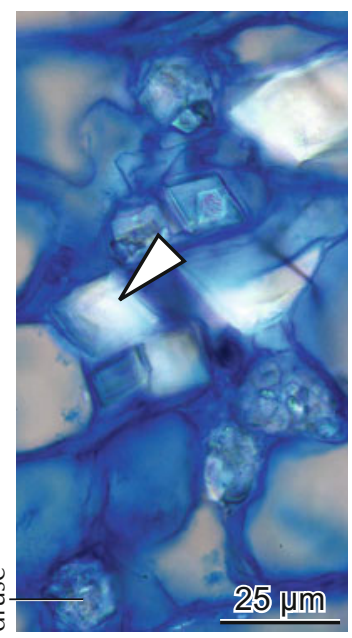

7.172 Prismatic crystals in Cycas revoluta.

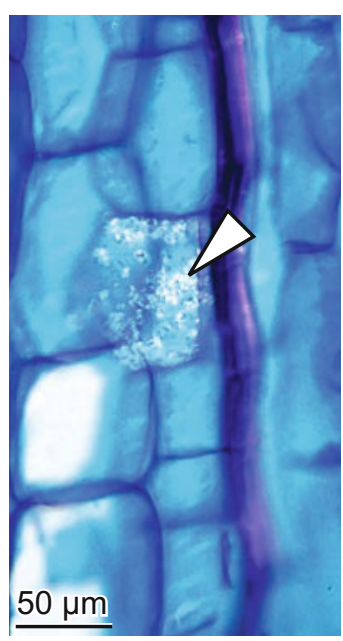

7.173 Crystal sand in Encephalartos hildebrandtii. 


\subsubsection{Ginkgoaceae}

Ginkgo biloba is the only living species in the family of Ginkgoaceae. Fan-shaped leaves are characteristic for the deciduous tree. The species is native to southwestern China. This "living fossil" is frequently cultivated in temperate zones.

The stem/root anatomy of Ginkgo biloba has been described in detail by Greguss 1955 .

The conifer-like xylem with annual rings is a product of secondary growth. Large earlywood and small latewood tracheids separate the square, radially arranged tracheids within the annual ring. Bordered tracheid pits are arranged in axial uni- to triseriate rows. Pit apertures are round in the earlywood and oval in the latewood. Axial parenchyma cells do not exist. Ray height varies between two and five cells. Ray cells are not lignified. Ray pits are intensively bordered and have slit-like apertures (taxodioid). Crystal druses occur in axial elongated chambers.

The phloem is characterized by alternating layers of sieve cells and lignified, thick-walled fibers. Companion cells are absent. Sieve fields on sieve cells occur on radial walls. A few resin ducts occur in the pith and the phloem. Sclereids occur, but are rare. Large crystal druses and large quantities of crystal sand are characteristic. The rhytidome of older bark contains many layers of phellem.

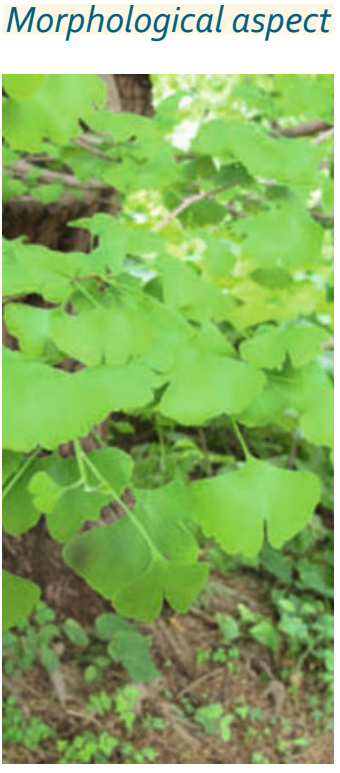

7.174 Leaves of Ginkgo biloba.

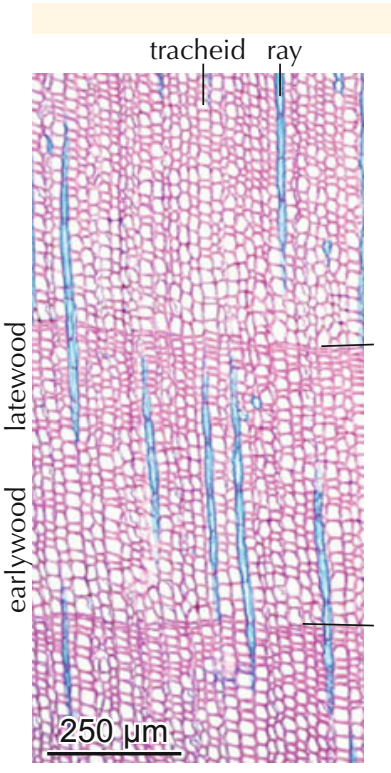

7.175 Tracheids in radial rows.

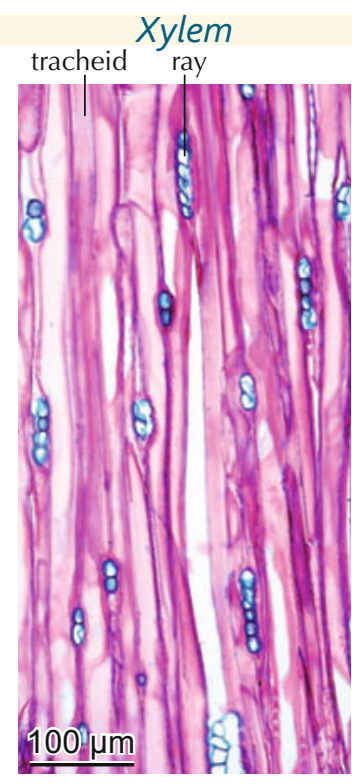

7.176 Short, unlignified, uniseriate rays.

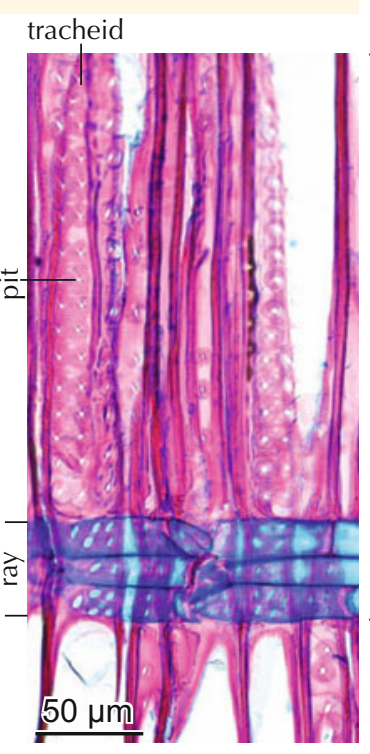

7.177 Tracheids and rays with pits.
Periderm

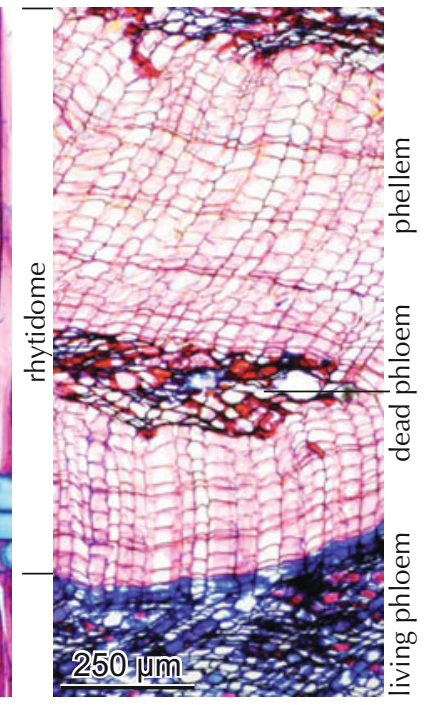

7.178 Phloem and rhytidome (phellogen and phellem).

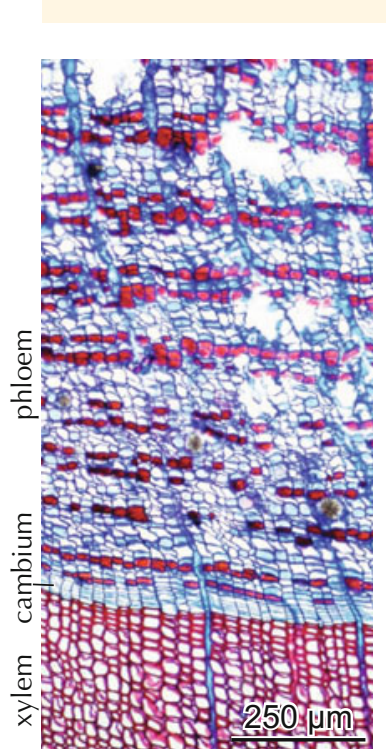

7.179 Alternating sieve cells and fibers.

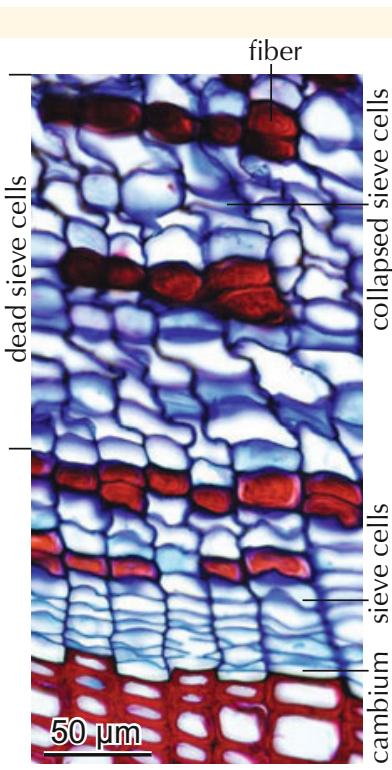

7.180 Active and dead phloem.

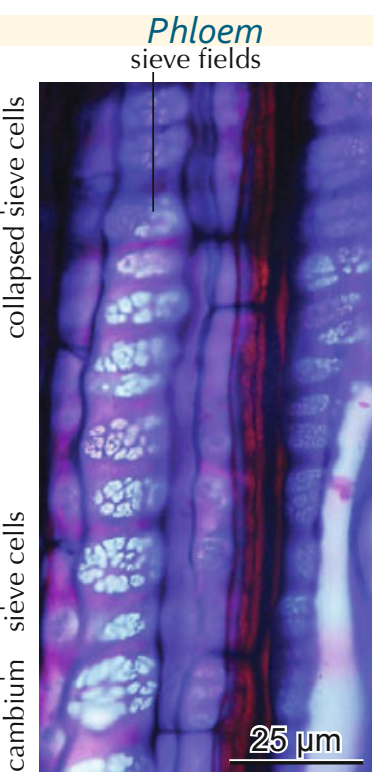

7.181 Sieve fields on radial walls of sieve cells.

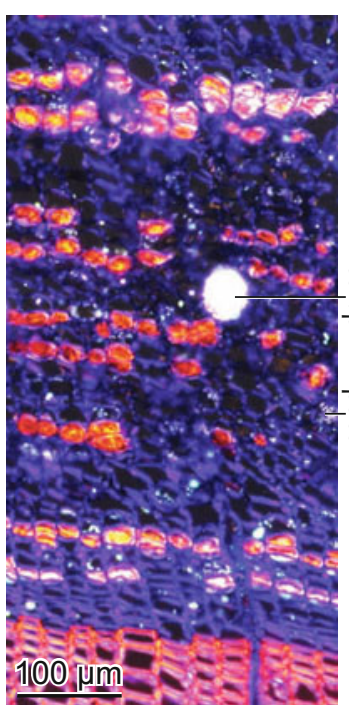

7.182 Crystal druses and crystal sand.

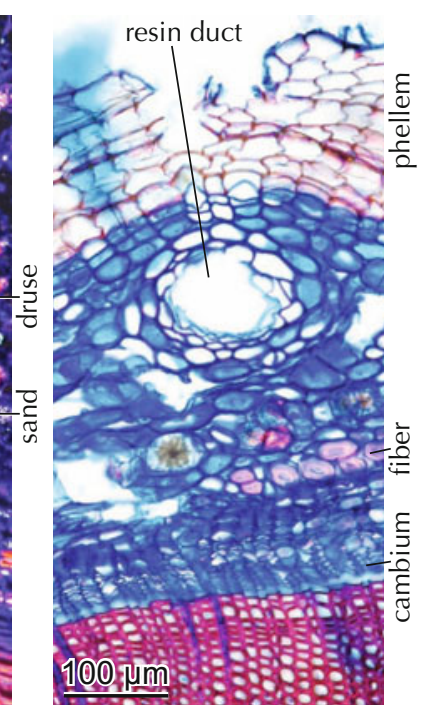

7.183 Resin duct in the phloem. 


\subsubsection{Conifers}

Today, seven families (Pinaceae, Araucariaceae, Podocarpaceae, Cephalotaxaceae, Cupressaceae, Taxodiaceae, Sciadopityaceae) are recognized within the conifers worldwide, together containing approximately 630 species. Conifers of the Pinaceae dominate the boreal zone in the Northern Hemisphere. Araucariaceae and Podocarpaceae are families of the Southern Hemisphere.

Plant growth forms and the forms of reproduction organs greatly vary. The presence or absence of heartwood is characteristic for many species. Stems on extreme sites reduce the xylem to radial strips.

\section{Conifers with one stem}

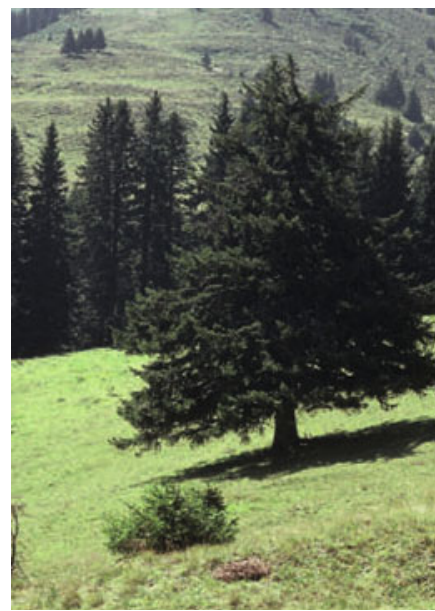

7.184 Picea abies, Norway spruce, on a subalpine meadow.

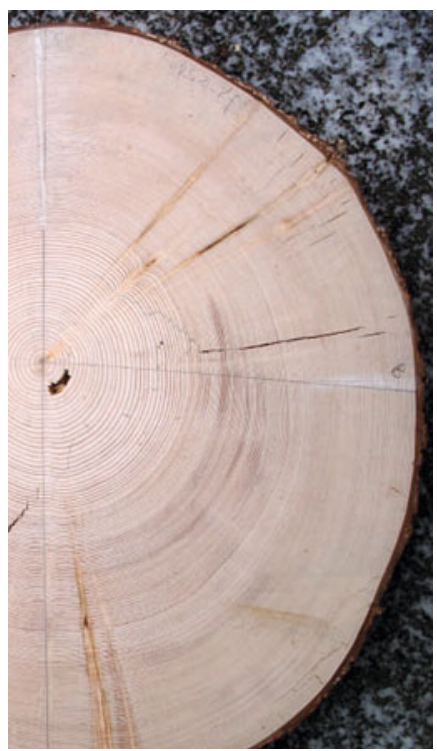

7.188 Picea abies without heartwood.
Secondary growth is characteristic for all conifers. In common is the presence of square, radially arranged tracheids, often separated into earlywood and latewood. Only species growing in seasonal climates form more or less distinct annual rings. The presence or absence of axial parenchyma and axial and radial resin ducts in the xylem is species-specific. Pits on axial tracheids occur in uniseriate (e.g. Pinaceae) or muiltiseriate rows (Araucariaceae). Pit apertures are mostly circular. The absence or presence of ray tracheids differentiates large groups. The form of the ray parenchyma cells is very variable.

The phloem is characterized by sieve cells with radial sieve fields, parenchyma cells, fibers and sclereids.

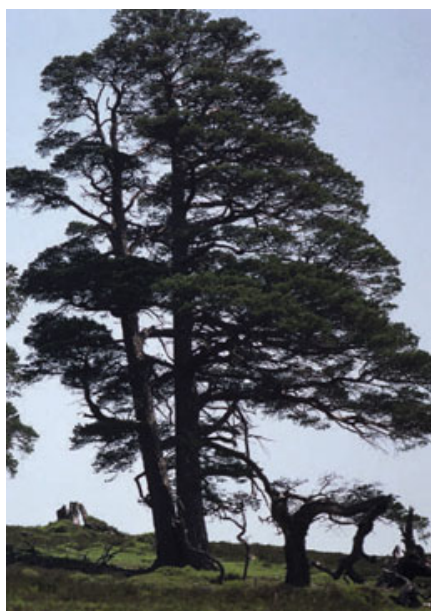

7.185 Pinus sylvestris, Scots pine, on an Atlantic meadow.

\section{Stem cross sections}

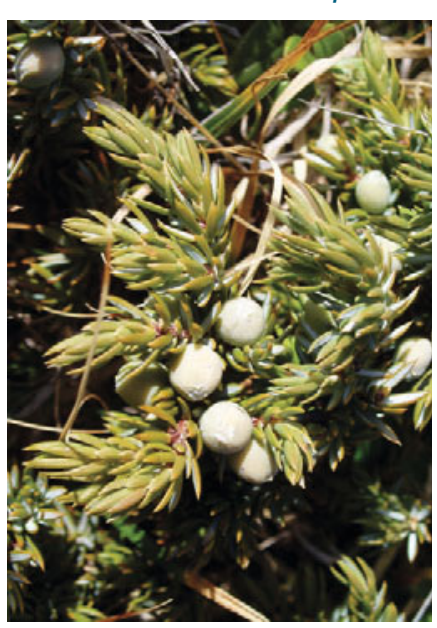

7.186 Fruits of Juniperus nana.

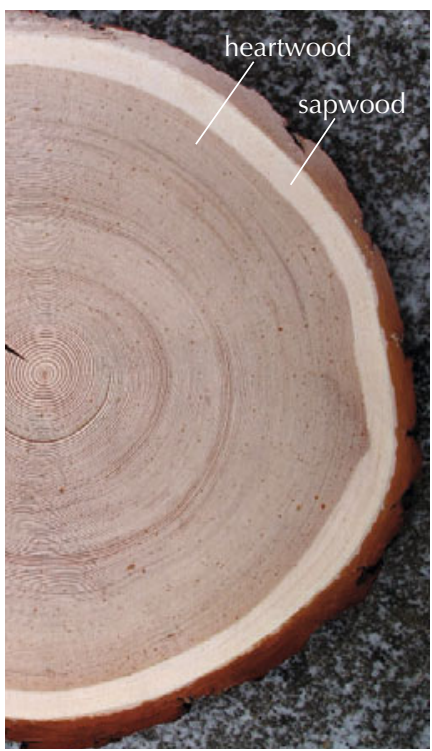

7.189 Pinus sylvestris with heartwood and sapwood.

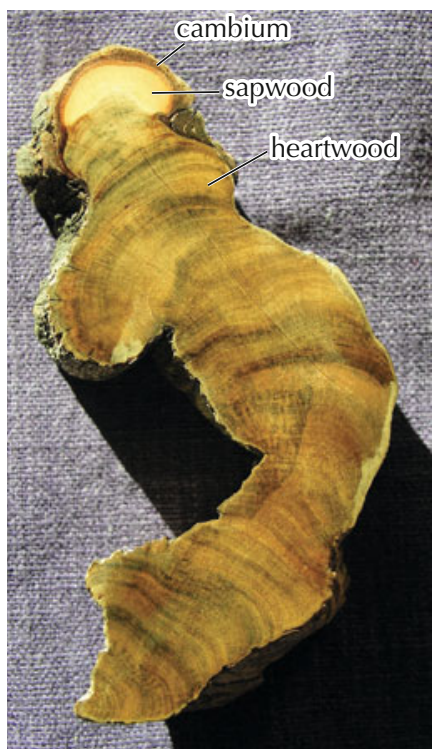

7.190 Radial stem strip with 840 annual rings of Juniperus sibirica.

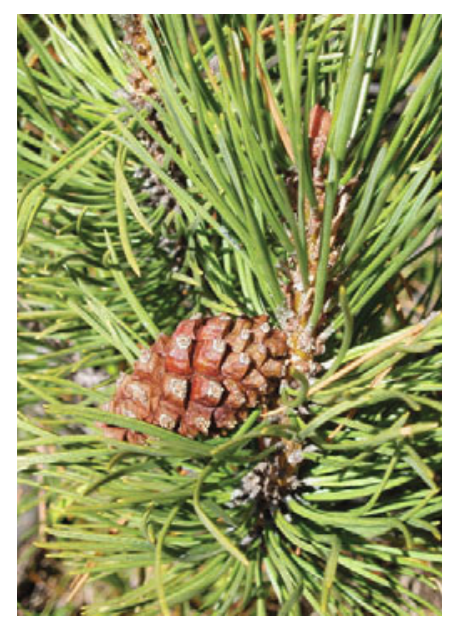

7.187 Cone of Pinus mugo.

\section{Secondary growth}

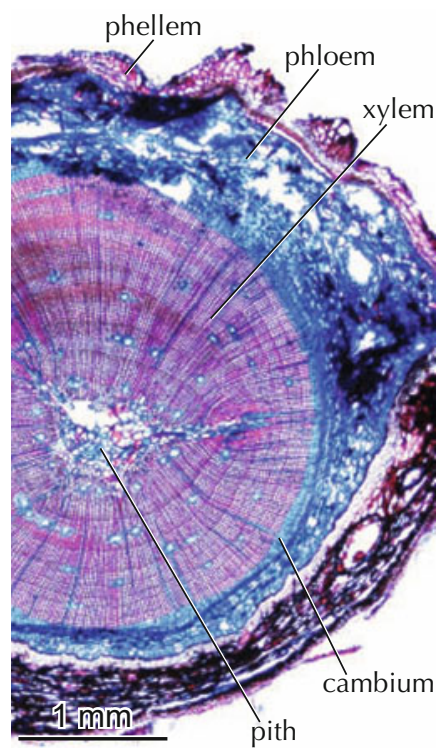

7.191 Twig of Pinus sylvestris 
Variable ring distinctness and presence or absence of resin ducts

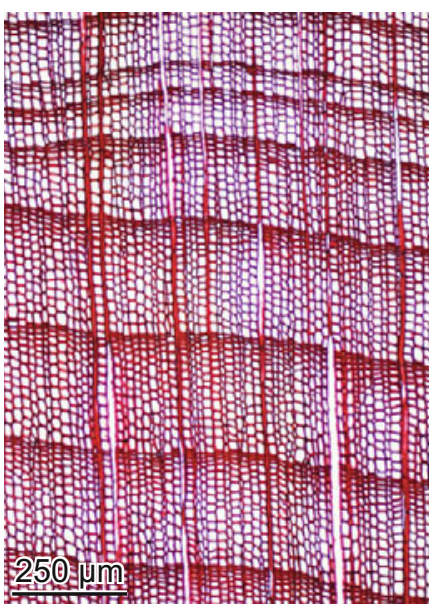

7.192 Distinct ring boundaries, without resin ducts, in Fitzroya cupressoides, South America.

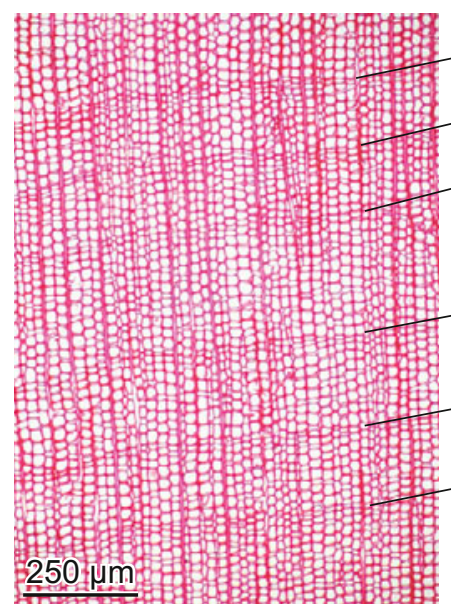

7.193 Weak ring boundaries, without resin ducts, in Podocarpus lambertii, subtropical South America.

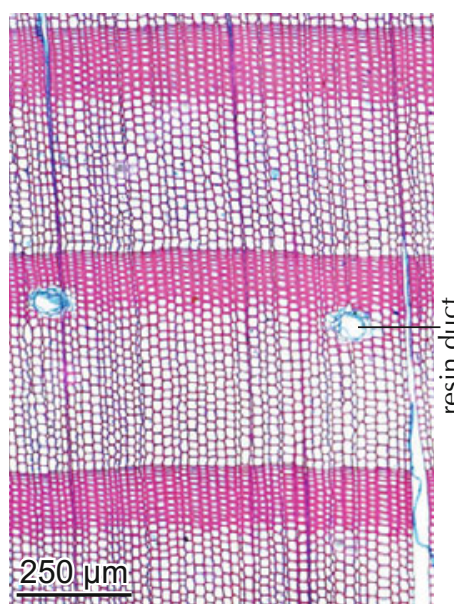

7.194 Distinct ring boundaries and resin ducts in Pinus banksiana, boreal North America.

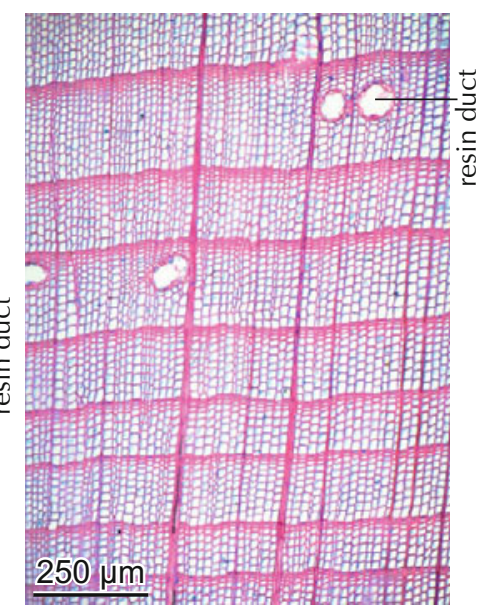

7.195 Distinct ring boundaries and resin ducts in Picea obovata, boreal Siberia.
Pits and helical thickenings on tracheids

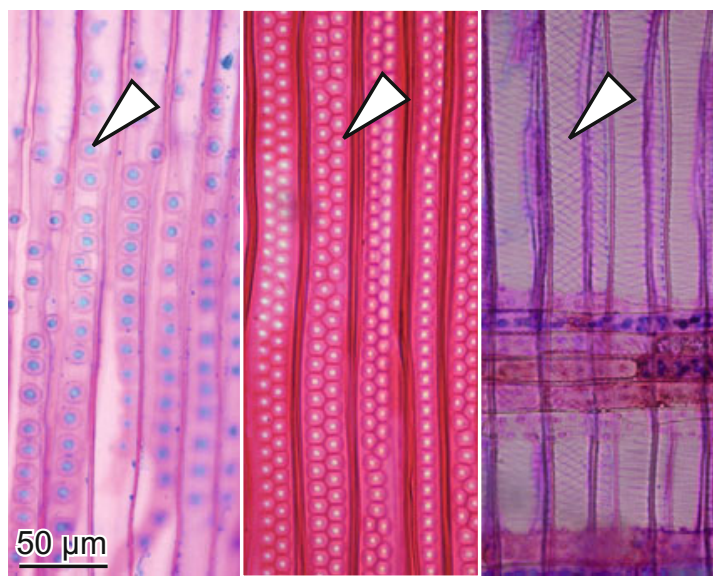

7.196 Left: Uniseriate pits in Pinus banksiana. Middle: Biseriate pits in Araucaria angustifolia. Right: Helical thickenings in earlywood tracheids in Pseudotsuga menziesii.

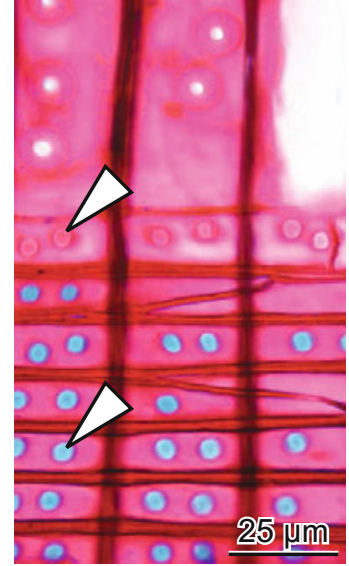

7.197 Uniform pitting: tracheid and ray pits with round apertures in Metasequoia glyptostroboides.

Ray pitting on central and border cells

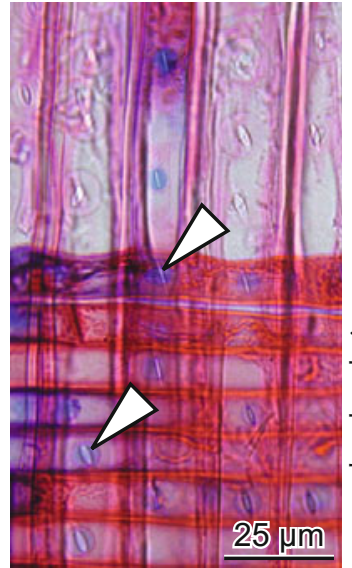

7.198 Uniform pitting: tracheid and ray pits with slitlike apertures in Podocarpus falcatus.

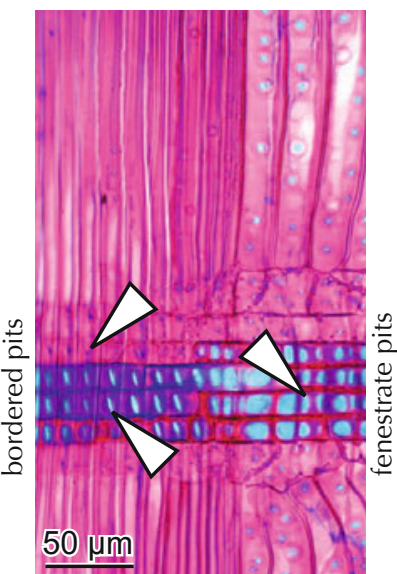

7.199 Heterogeneous pitting: fenestrate pits on ray-parenchyma cells and bordered pits with round apertures on ray tracheids and axial tracheids in Pinus sylvestris.
Structure of the phloem

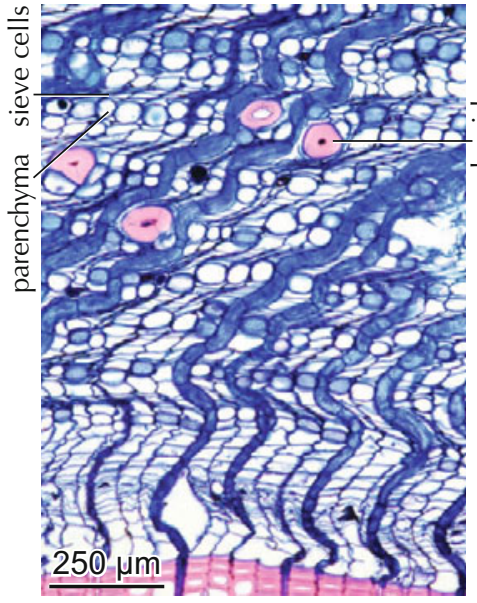

7.200 Alternating rows of sieve cells and parenchyma cells with a few isolated sclereids in Larix decidua.

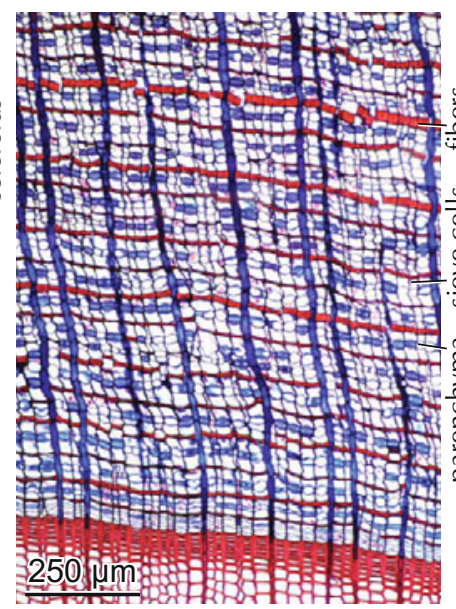

7.201 Alternating rows of sieve cells and parenchyma cells and fibers in Metasequoia glyptostroboides.

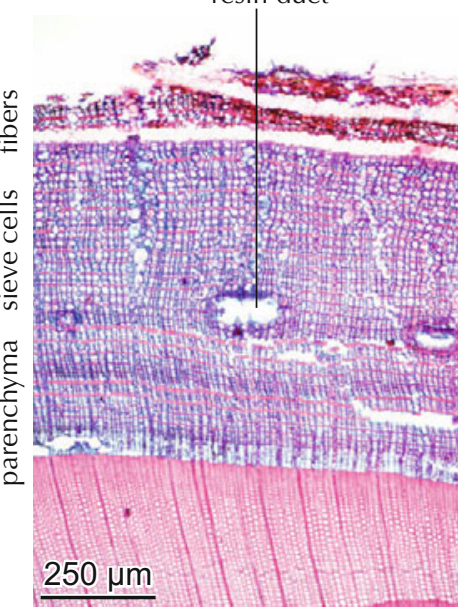

7.202 Resin ducts in the phloem of Juniperus communis.

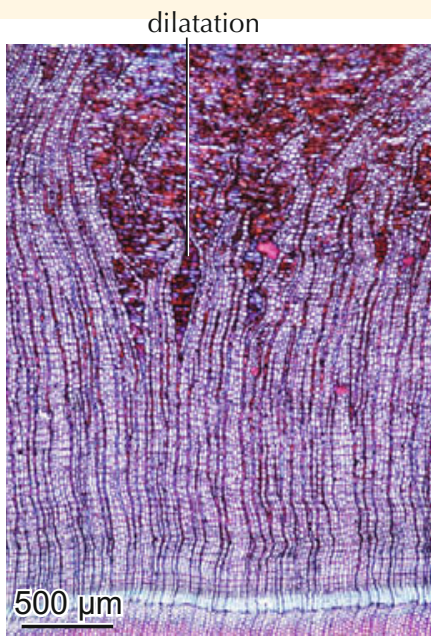

7.203 Ray dilatation in the phloem of Podocarpus falcatus. 


\subsubsection{Gnetales}

\section{Ephedraceae}

Ephedra is the only genus within the family of Ephedraceae. All 30-45 leaf-less species grow on dry sites, mostly in arid regions. Their growth forms vary from dwarf shrubs and shrubs to lianas (Ephedra campylopoda).

Secondary growth is characteristic for all Ephedra species, and growth rings are generally distinct. The xylem is composed of vessels, tracheids, "fiber tracheids" and rays. Foraminate perforation plates with distinct borders characterize vessels. Cell walls of vessels and tracheids frequently contain helical thickenings and bordered pits with round apertures and distinct, unlignified tori. "Fiber tracheids" are hybrids between parenchyma cells and tracheids: pits are simple (parenchyma-like), but horizontal walls are absent (tracheid-like). Classical parenchyma cells were not observed. Crystal sand is frequently present in most unlignified parts of the xylem and phloem. Dark-stained substances occur mainly in the pith.

The phloem is characterized by parenchyma cells, fibers, sclereids and sieve elements (sieve cells) with sieve fields on radial walls. Companion cells are absent. All large rays are dilated. Older stems contain a distinct, multilayered rhytidome.

See also Carlquist 1992.

Macroscopic aspect

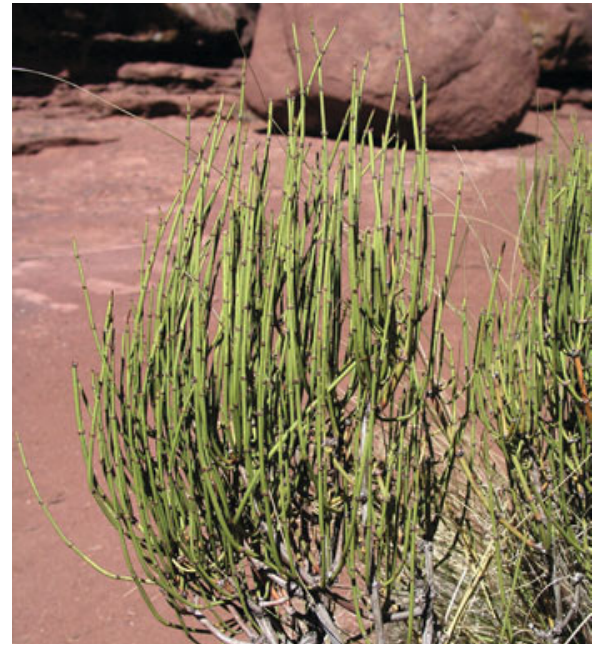

7.204 Ephedra sp. on a dry site in southwestern North America.

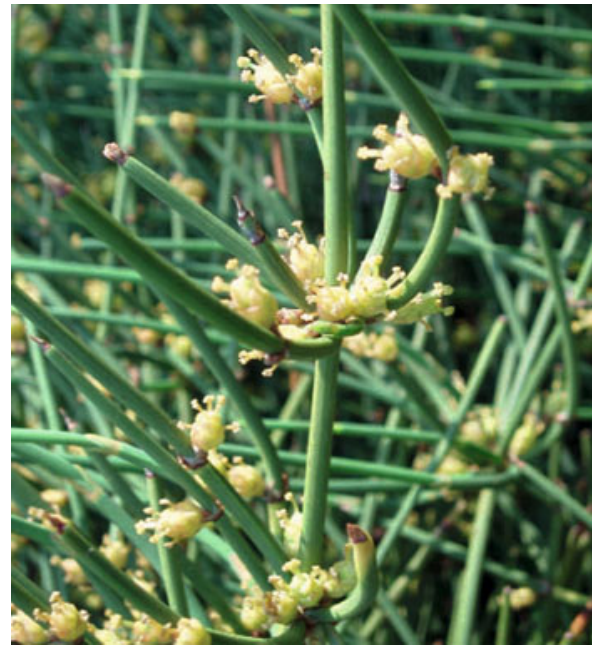

7.205 Ephedra sp. with flowers. Photo: A. Moehl.

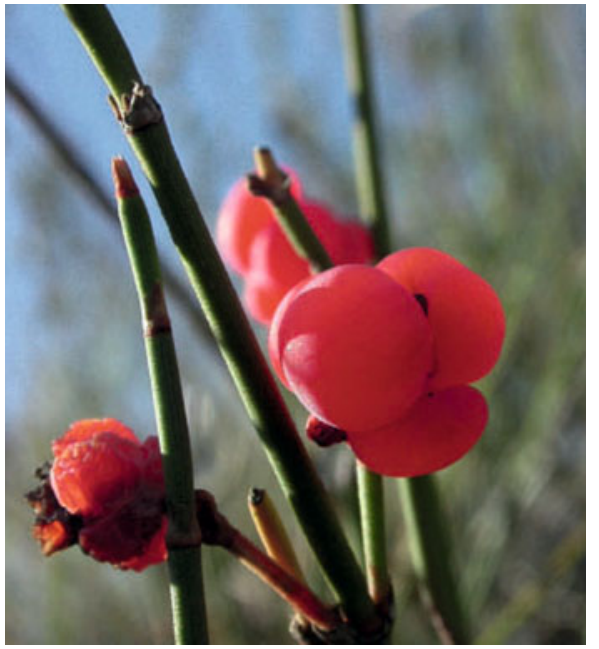

7.206 Ephedra distachya ssp. helvetica with fruits. Photo: A. Moehl.

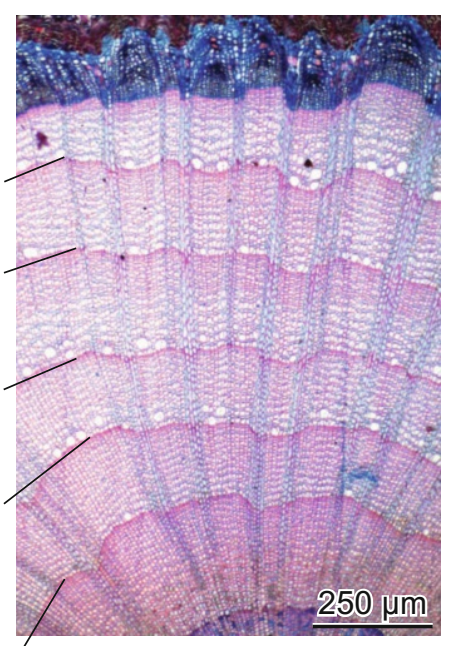

7.207 Dwarf shrub Ephedra nebrodensis with distinct annual rings.

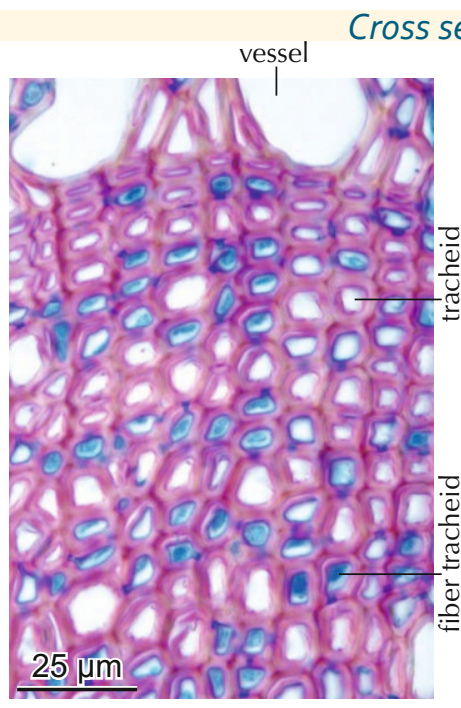

7.208 Latewood of Ephedra trifurcata with tracheids, "fiber tracheids" and vessels.

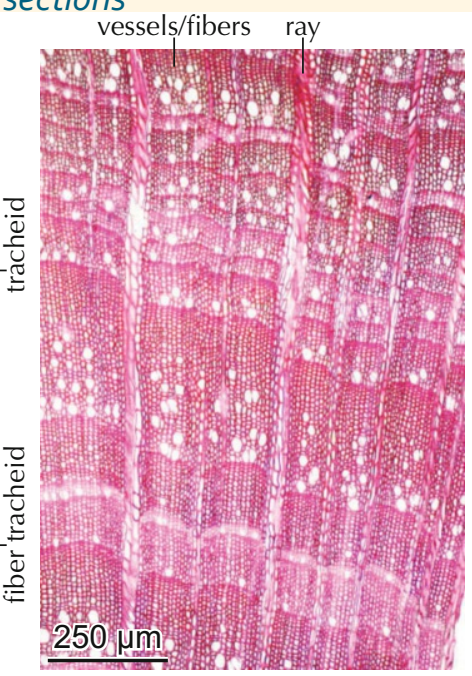

7.209 Liana Ephedra campylopoda with irregular radial growth.

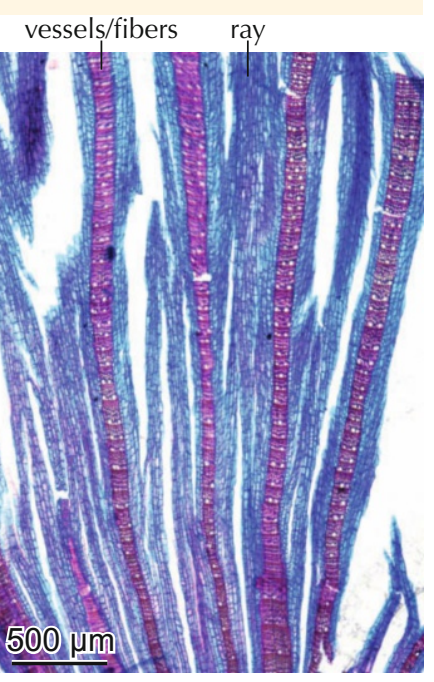

7.210 Shrub Ephedra gerardiana on a dry site at high altitude, Ladakh, India, 4,400 m a.s.l. 


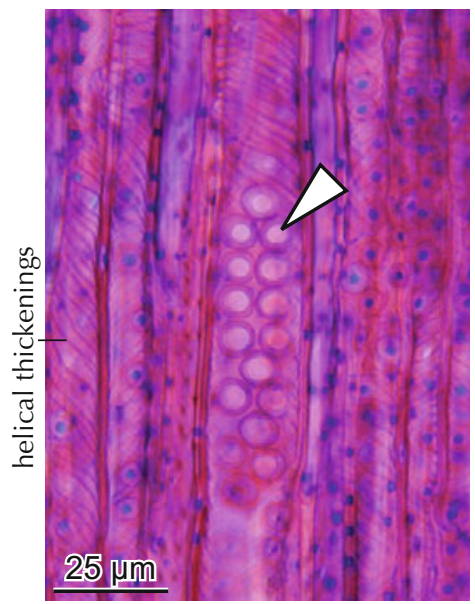

7.211 Vessel with a foraminate perforation in Ephedra viridis.

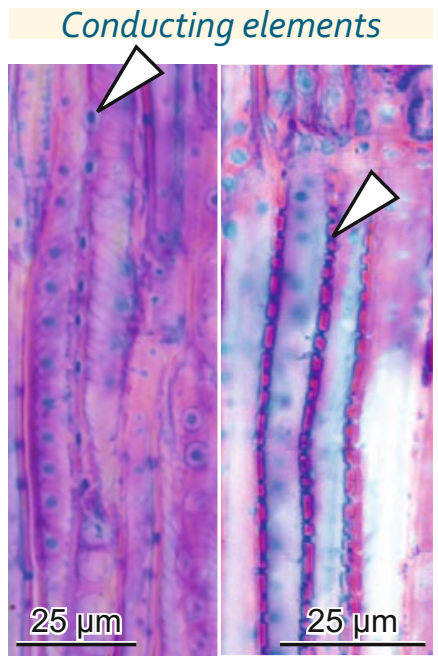

7.215 Longitudinal section of Ephedra trifurcata. Left: Tracheids with bordered pits. Right: "Fiber tracheids" with simple pits.

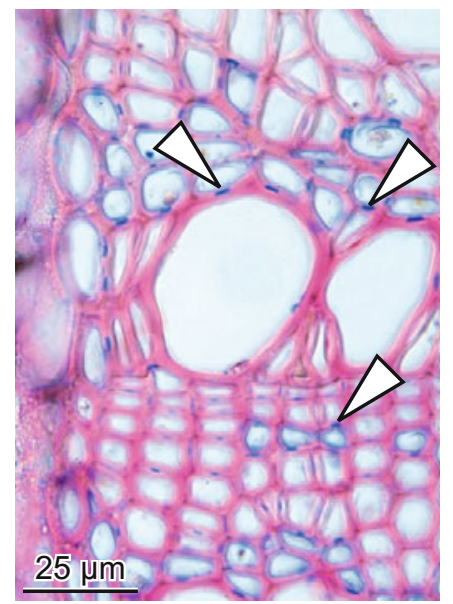

7.212 Pits with unlignified tori in "fiber tracheids" in Ephedra viridis.

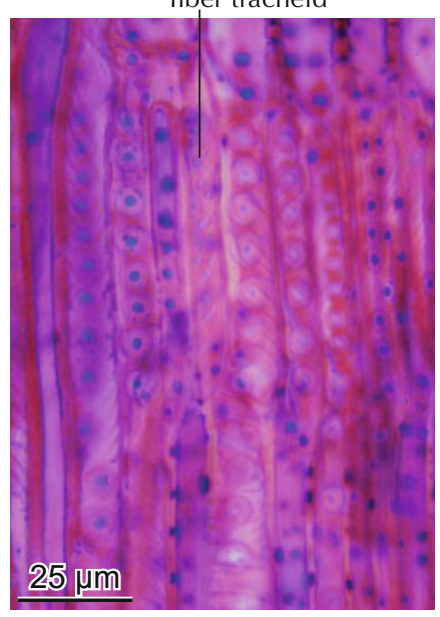

7.213 Vessel and tracheids with bordered pits and a "fiber tracheid" with simple pits in Ephedra viridis.

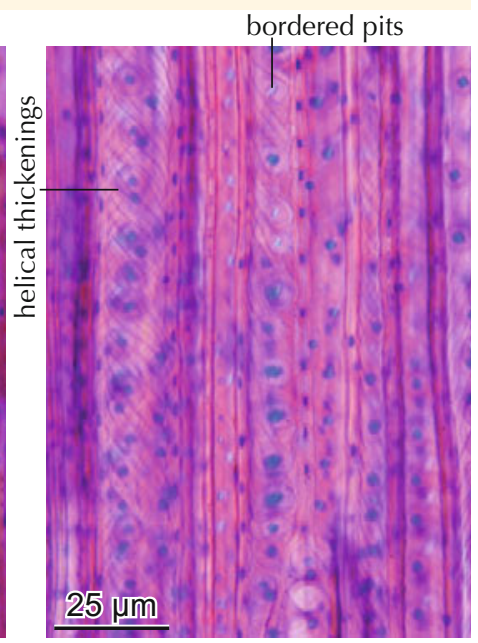

7.214 Tracheids with bordered pits and helical thickenings in Ephedra distachya.

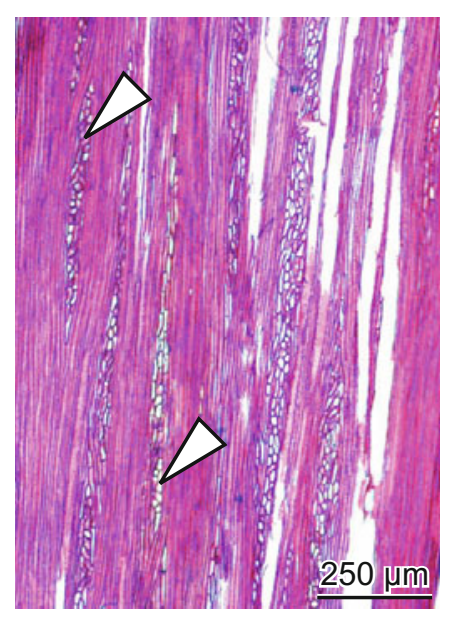

7.216 Tri- to six-seriate rays with irregularly formed cells in Ephedra viridis.

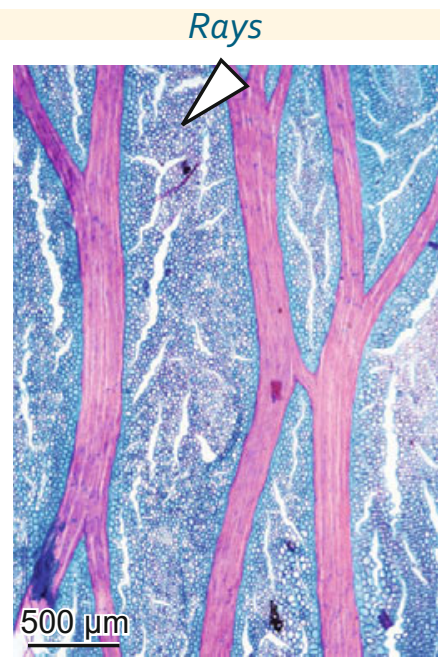

7.217 Extremely large, unlignified rays between lignified tracheid/vessel strips in Ephedra gerardiana.

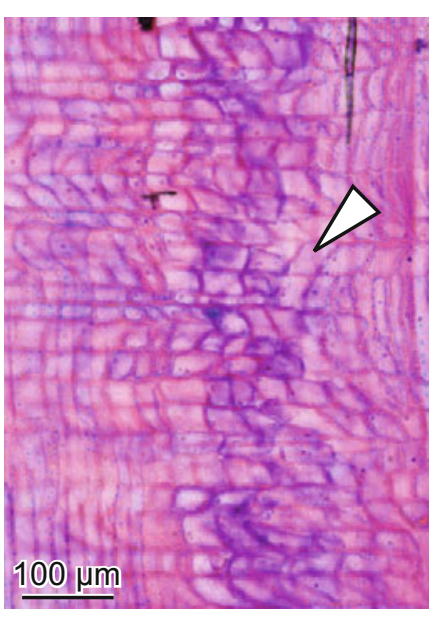

7.218 Prostrate and square ray cells in Ephedra trifurcata.

\section{Ray pitting}

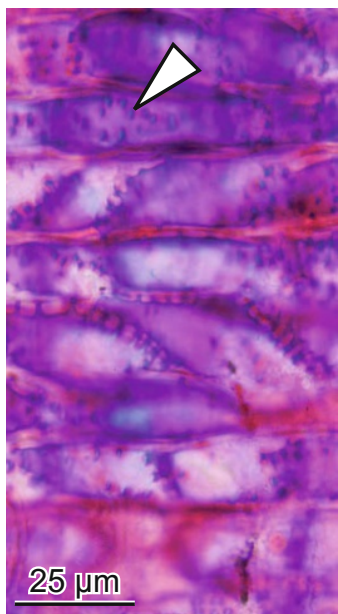

7.219 Lateral walls with simple pits in Ephedra viridis.

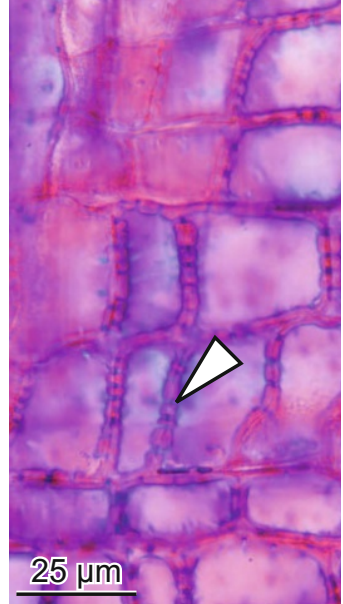

7.220 Axial and radial walls with simple pits in Ephedra viridis.
Crystal sand

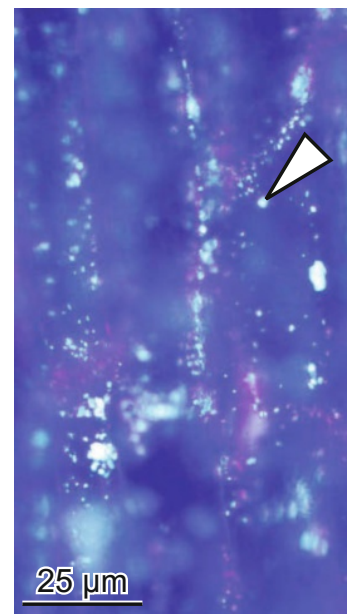

7.221 Crystal sand in Ephedra gerardiana.

Bark

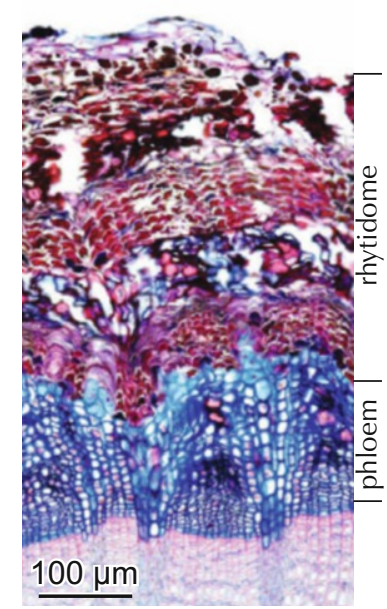

7.222 Living phloem and dead phellem/phloem parts (rhytidome) in Ephedra nebrodensis.

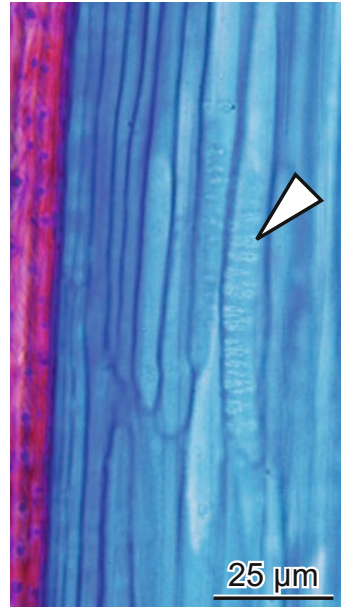

7.223 Sieve fields on radial walls of sieve cells in Ephedra viridis. 


\section{Welwitschiaceae}

Welwitschia mirabilis is the only species within the family of Welwitschiaceae. The below-ground stem/root and the aboveground continuously growing two leaves are characteristic. The plant grows in the arid zone of Namibia and Angola. The stem/ root anatomy was described in detail by Carlquist \& Gowans 1995.

\section{Anatomy of the leaf}

A layer of palisade cells is situated between anatomically undifferentiated epidermal surfaces. Open collateral vascular bundles are located in the central parenchymatic tissue.

\section{Anatomy of the female flower stalk}

Collateral open vascular bundles are embedded in a parenchymatic tissue and a few ducts. The irregularly distributed bundles are arranged around a pith. The bundles consist of tracheids with annular thickenings and round, bordered pith-like structures. Phloem cells expand shortly after their formation and remain as collapsed structures.

\section{Morphology of the plant}

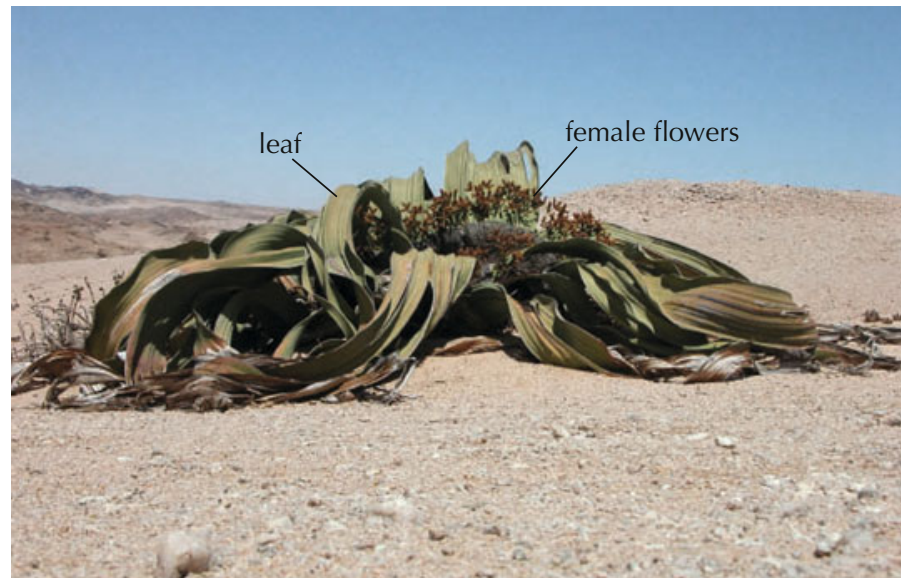

7.224 Welwitschia mirabilis in the Namibian desert. Photo: P. Poschlod.

\section{Anatomy of the female flower stalk}

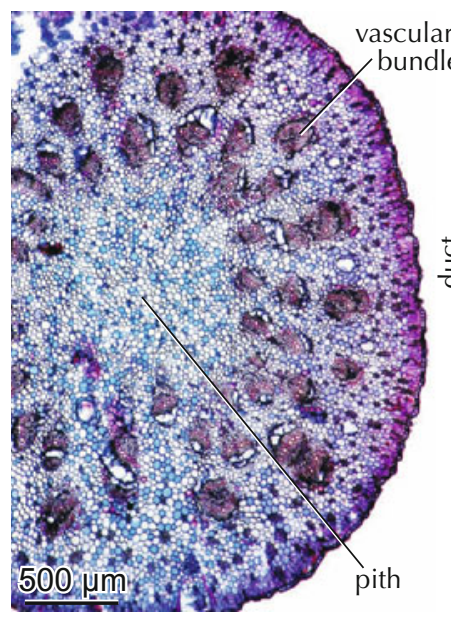

7.227 Distribution of vascular bundles.

\section{Stem/root}

The arrangement of the xylem and phloem is normally chaotic, however, in central parts of the stem successive cambia produce several layers of xylem/phloem zones. A circular, closed xylem/phloem is absent, a lateral vascular cambium seems to be absent, therefore the form of vascular bundles remains. Thin-walled, unlignified rays separate the bundles. The xylem consists of thick-walled vessels with simple perforation plates, tracheids and thin-walled, unlignified parenchyma cells. Radial vessel and tracheid walls contain bordered pits without tori and with round to slit-like apertures. Pits are often arranged in alternate position. Parenchyma is pervasive. In parenchymatic zones, including rays, there are very thick-walled fibers, containing a mantle of small prismatic crystals. Crystal sand occurs in most parenchyma cells.

The phloem consists primarily of very thick-walled gelatinous fibers. A few thin-walled sieve elements occur between them.

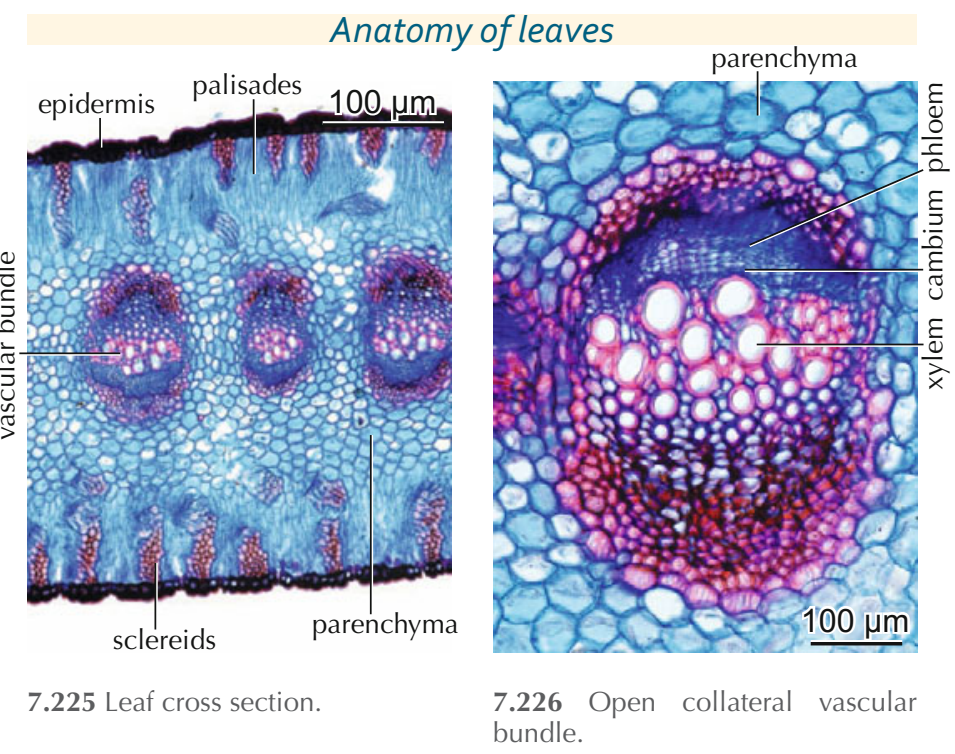

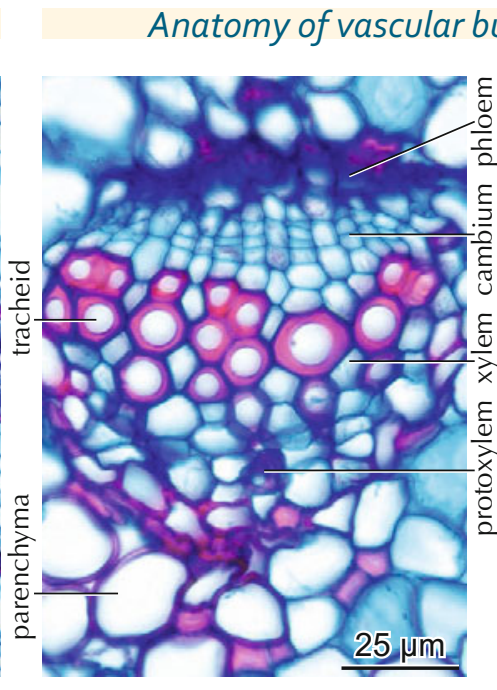

7.229 Cambium between the xylem and the phloem.

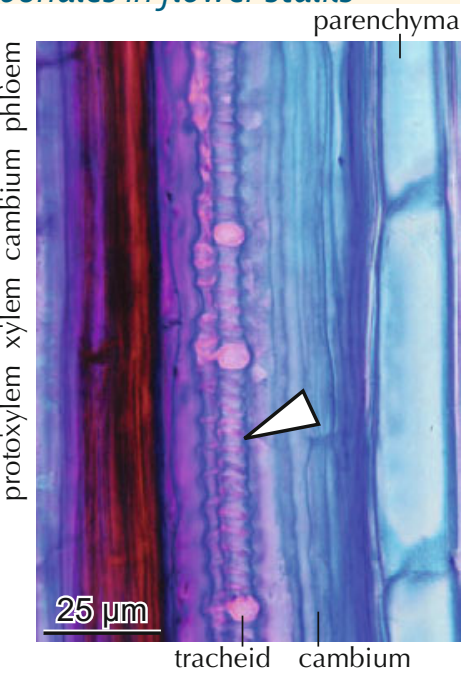

7.230 Annular thickenings in tracheids. 
Anatomy of the stem/root

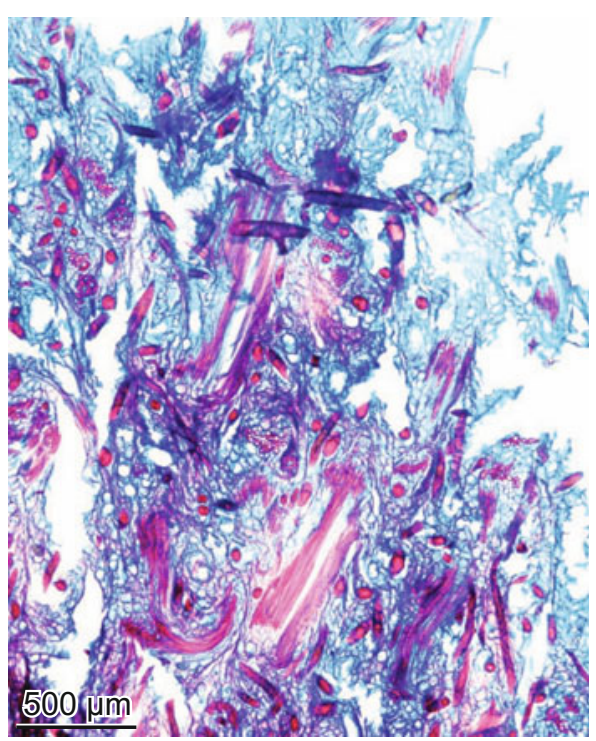

7.231 Chaotic orientation of the tissue in external parts of stems.
Anatomy of the stem

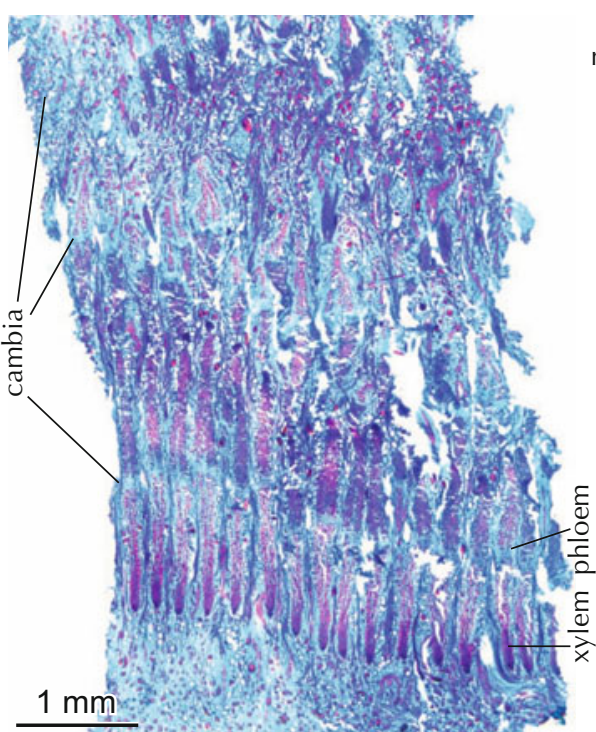

7.232 Successive cambia between radially elongated vascular bundles in internal parts of stems.
Anatomy of vascular bundles

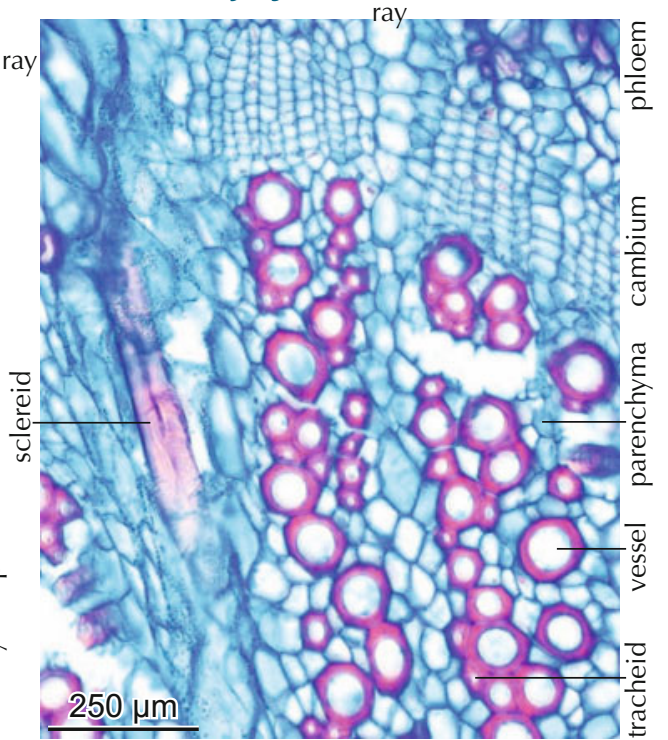

7.233 Cambial zone of an open collateral bundle.

Anatomy of vascular bundles in the stem/root

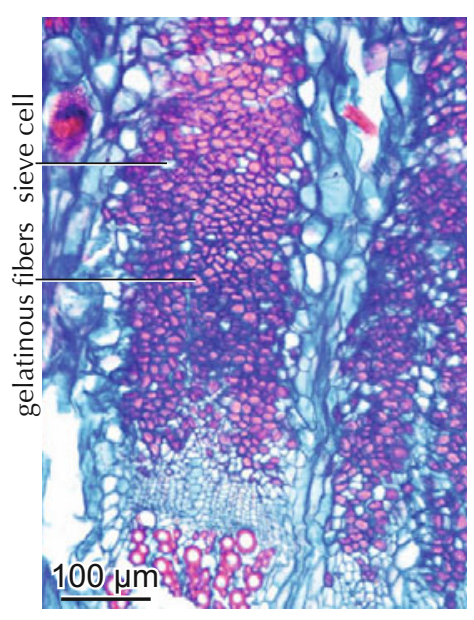

7.234 Phloem with thick-walled gelatinous fibers.

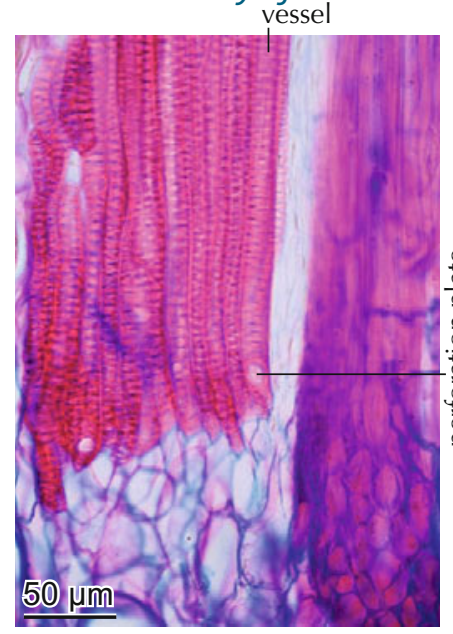

7.235 Vessels with perforation plates and tracheids.

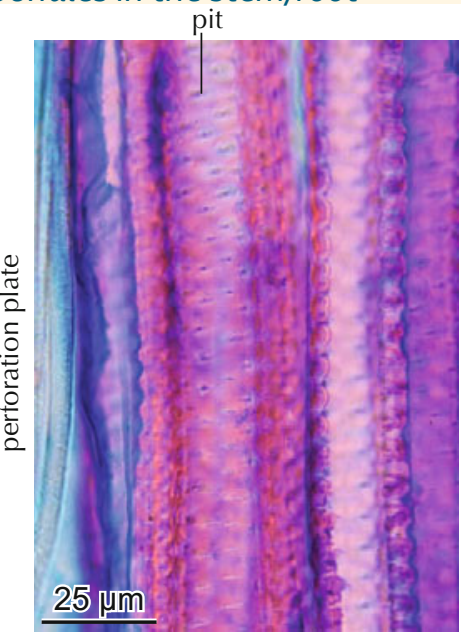
Sclereids and crystals

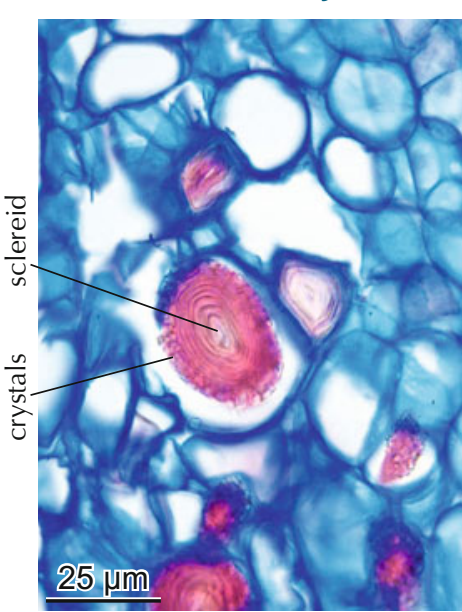

7.239 Layered sclereids surrounded by crystals.
7.236 Biseriate bordered pits.

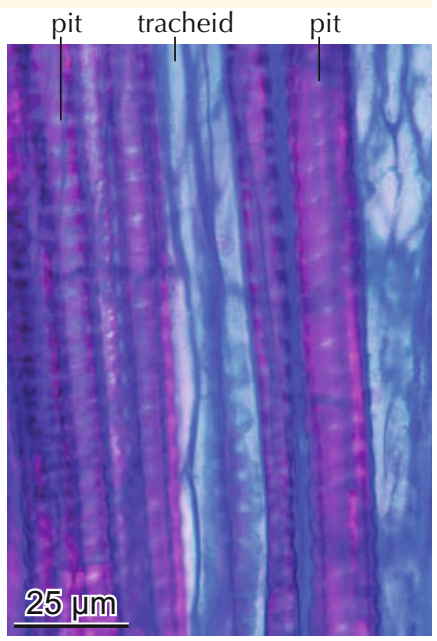

7.237 Uniseriate bordered pits.

Anatomy of the cortex

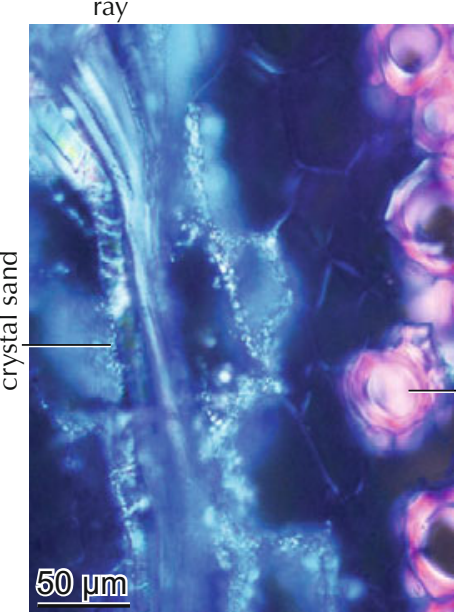

7.240 Crystal sand in thin-walled parenchyma cells. epidermis

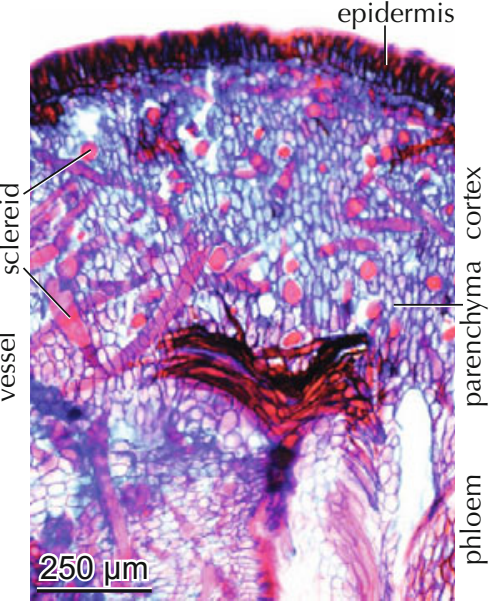

7.241 Thin-walled parenchyma and sclereids. 


\section{Gnetaceae}

Gnetum is the only genus within the family of Gnetaceae. All 30 species, lianas and small trees with broad leaves, grow in the tropics. Described here is the small tree Gnetum gnemon from the Philippines. Its anatomy is described in detail by Carlquist 1996.

Secondary growth is characteristic. Growth rings are generally absent, however, density variations indicate intra-annual differences in climatic growing conditions. The xylem is composed of vessels, tracheids, septate fibers, axial parenchyma cells and rays. Vessels are solitary. Simple and foraminate perforation plates with distinct borders characterize vessels, with both types occurring within the same individual. Vessel walls contain small, vestured pits with oblique apertures. Radial walls of septate tracheids are perforated by large bordered pits. Round apertures and distinct unlignified tori are characteristic. Helical thickenings occur, but are rare. Horizontal walls of septate fibers are not lignified. Axial parenchyma is dominantly vasicentric paratracheal and occasionally apotracheal. The width of the homocellular rays with prostrate cells varies between one and five rows. Ray pits are slightly to distinctly bordered. Many small prismatic crystals are deposited in ray and pith cells.

The phloem is characterized by a few parenchyma and sieve elements (sieve cells) with sieve fields on radial walls. Companion cells are absent. Sieve cells collapse soon after formation. Rays are dilated. Gelatinous fibers and small crystals occur in the cortex and the phloem. Sclereids form a band between the cortex and the phloem. The phellem is interrupted by lenticels.

\section{Morphology of the plant}

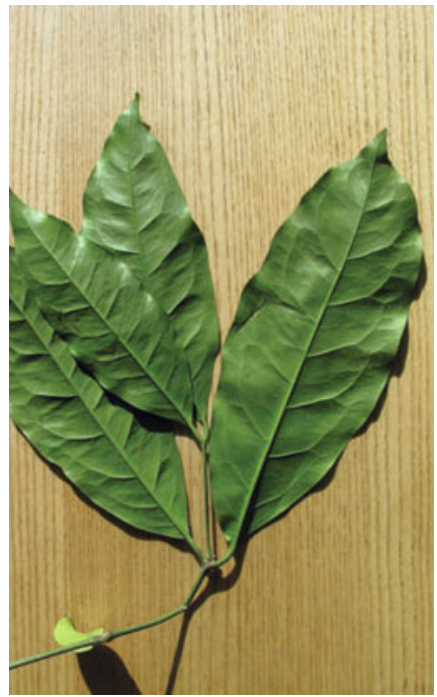

7.242 Broad, thin leaves of Gnetum gnemon.

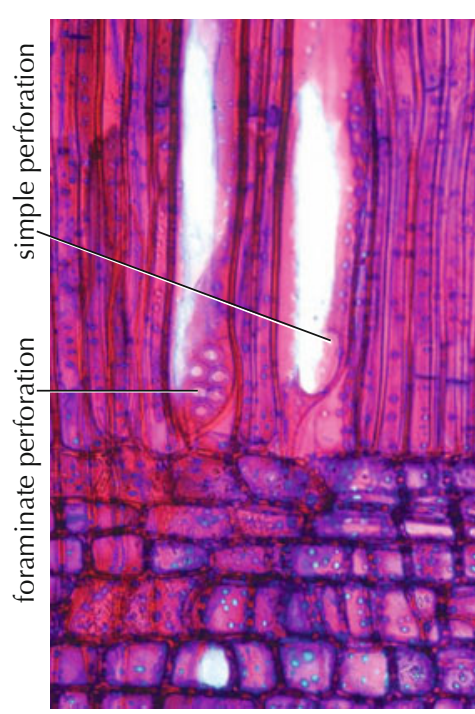

7.246 Perforation plates.

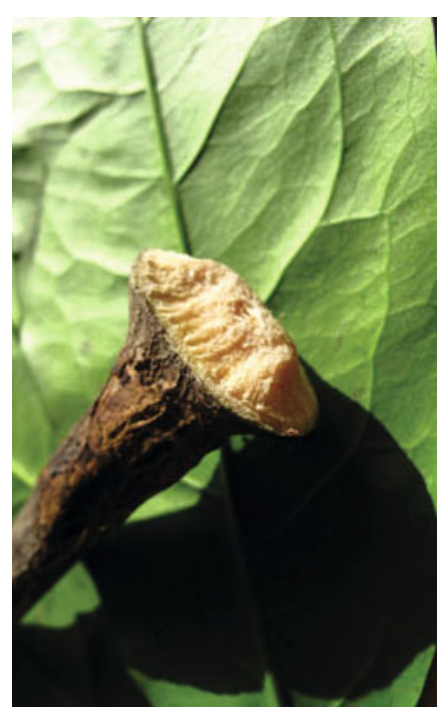

7.243 Breaking zone of a twig (apoptosis).

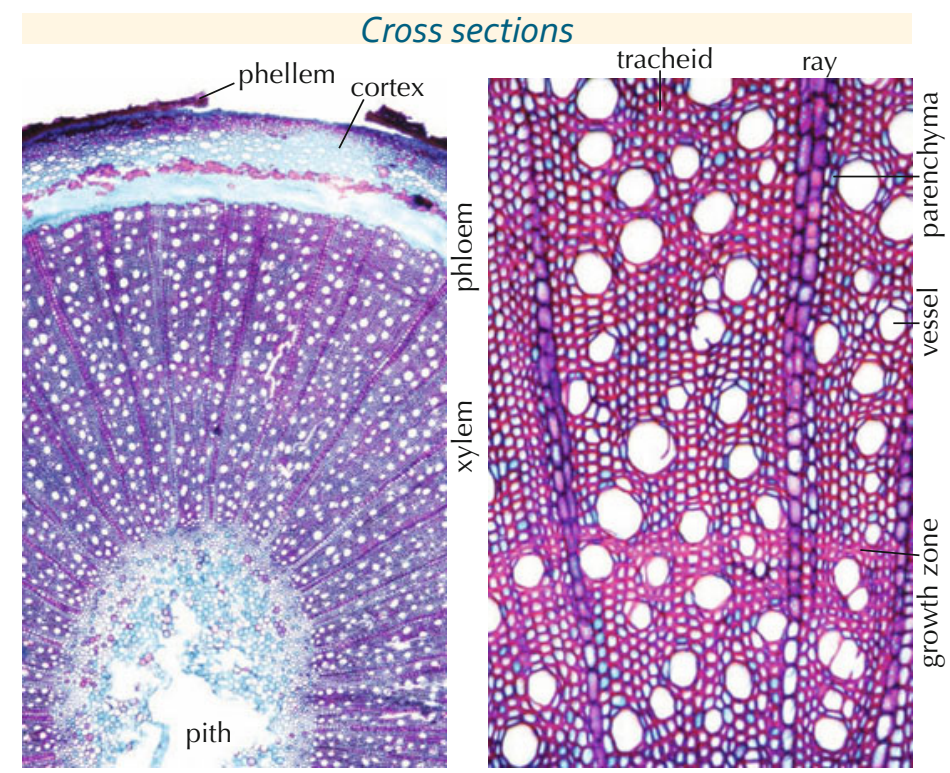

7.244 Pith, xylem and bark.

7.245 Xylem with a growth zone.

Perforation plates and pits

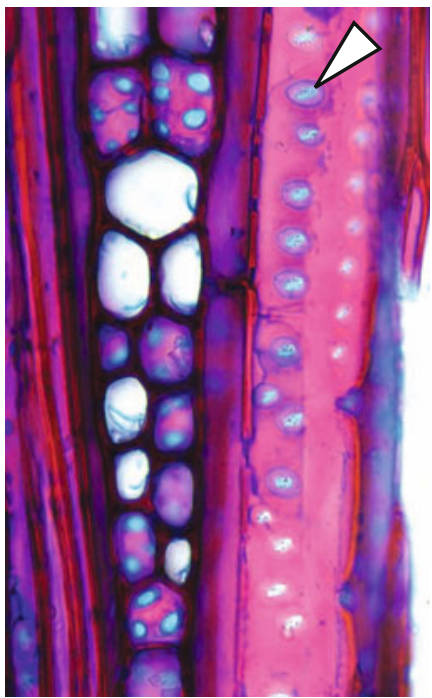

7.247 Vestured intervessel pits

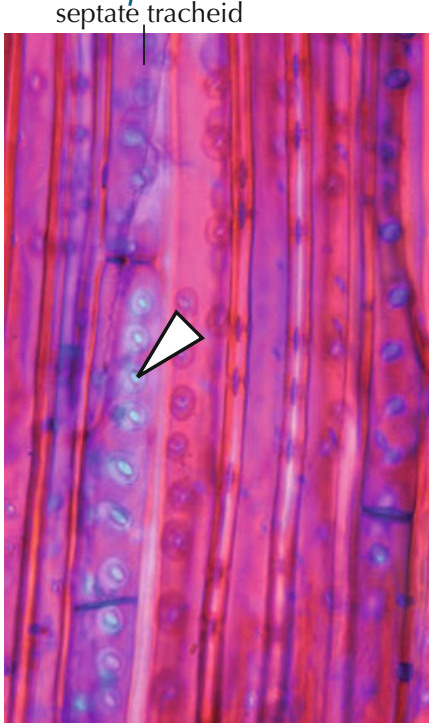

7.248 Bordered pits on septate tracheids.

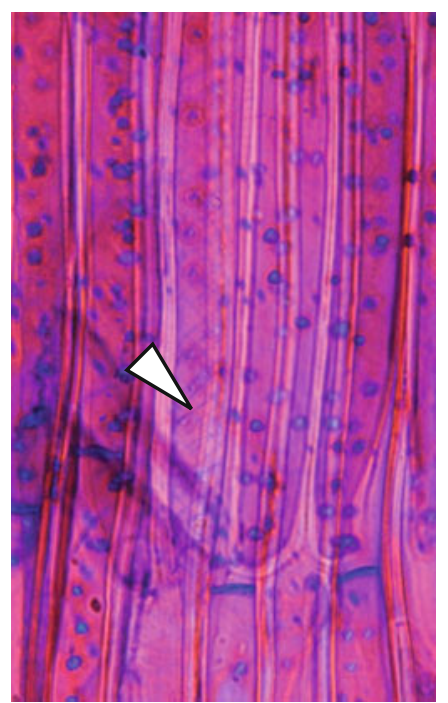

7.249 Thin helical thickenings in tracheids. 
Rays

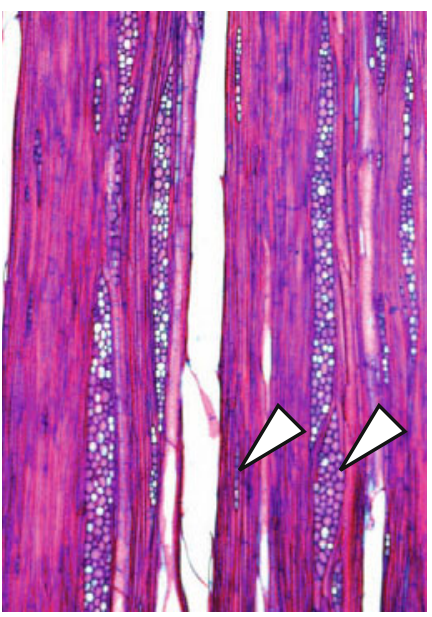

7.250 Uni- to five-seriate homocellular rays.

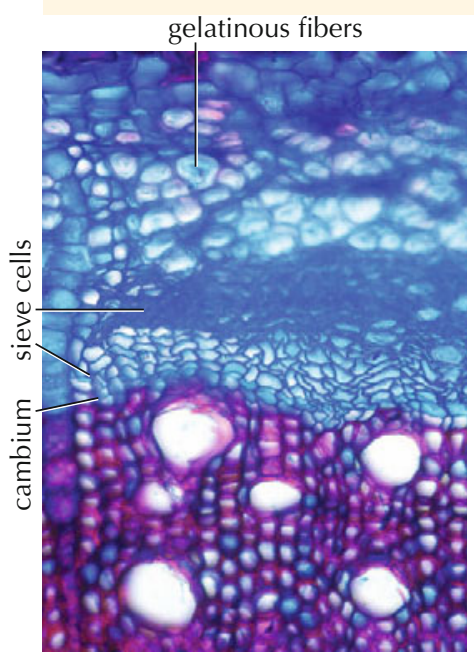

7.254 Conducting and collapsed sieve elements and gelatinous fibers.

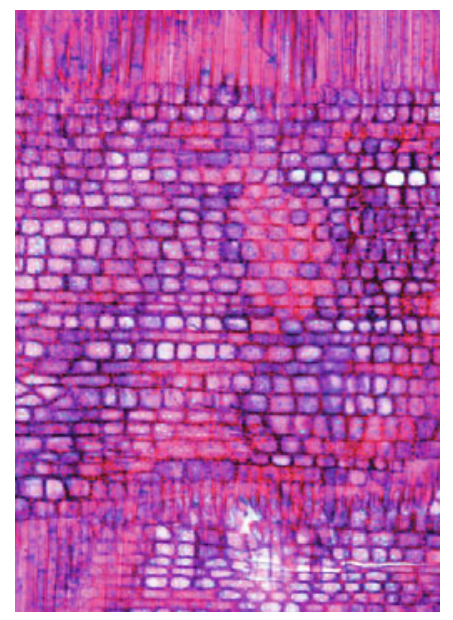

7.251 Homocellular ray with prostrate and square cells.

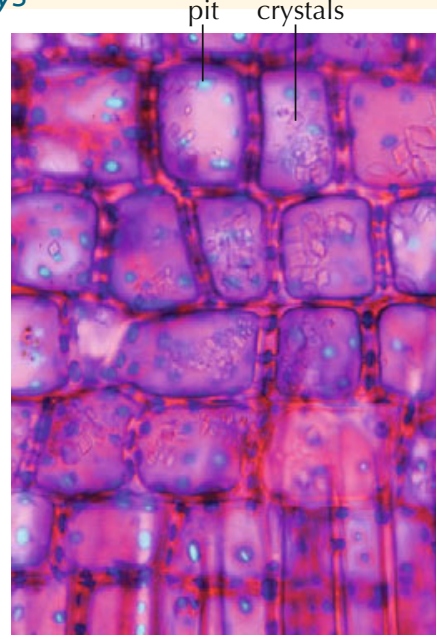

7.252 Ray cells with pits and small prismatic crystals.

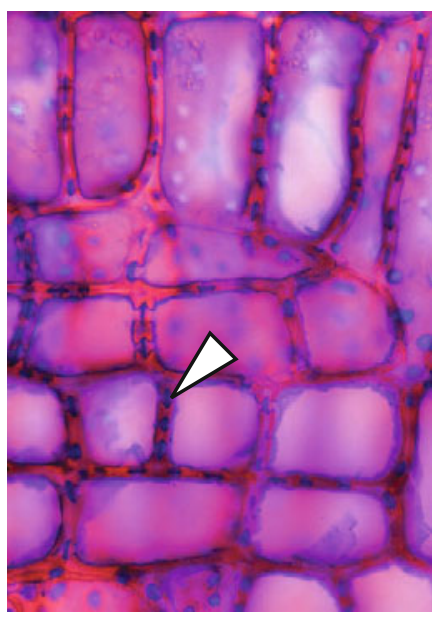

7.253 Ray cells with bordered pits

Bark

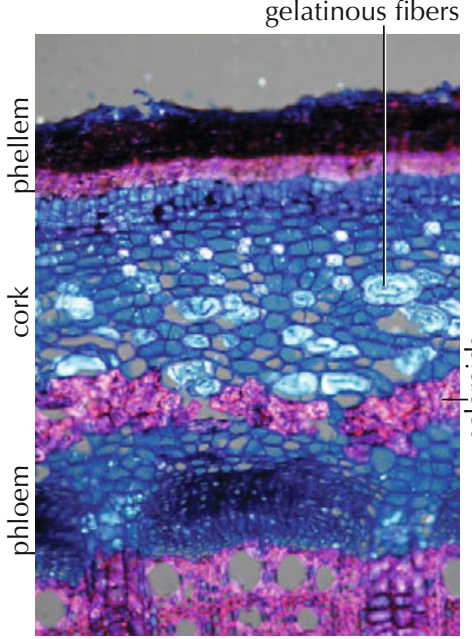

7.255 Phloem, cortex with sclereids and gelatinous fibers and periderm.

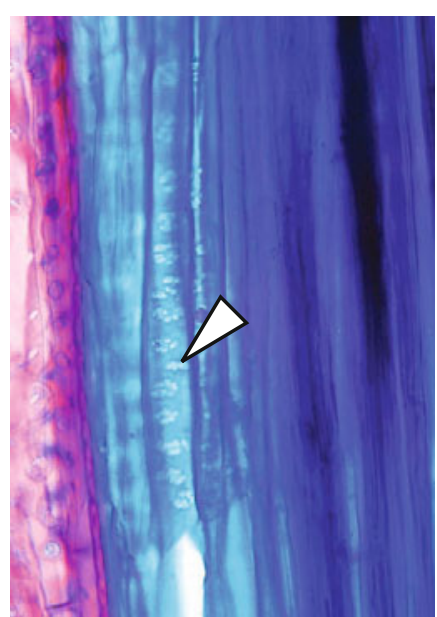

7.256 Sieve fields in sieve cells

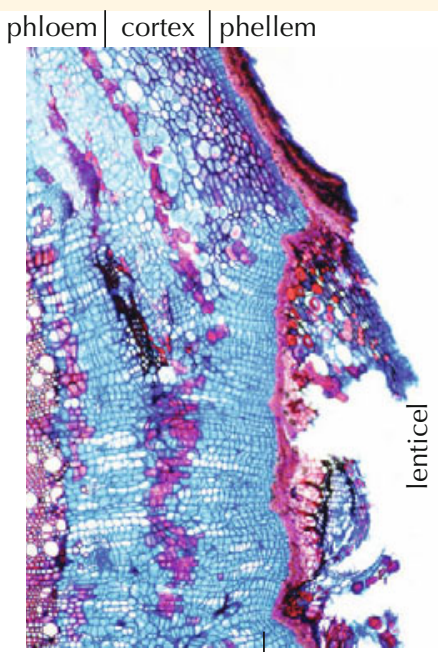

phelloderm

7.257 Lenticel.

\section{Gnetales: Conifers or Angiosperms?}

Gnetales are seed plants (spermatophyta) that are taxonomically related to conifers. Bordered pits on tracheids in the xylem confirm that. However, many stem-anatomical features show relations to angiosperms. A few features are common to all three families: the presence of vessels, tracheids with large bordered pits and small crystals in parenchyma cells and sclereids in the bark. Each genus has its own "specialty".

Ephedra mainly forms leafless shrubs and prefers arid climates or dry sites in the Northern and Southern Hemisphere. The xylem has no axial parenchyma but "fiber tracheids" with simple pits. All perforation plates are foraminate.

Welwitschia mirabilis forms a subterranean stem and two continuously growing leaves. The plant is geographically isolated and occurs only in the desert of Namibia. The xylem has successive cambia and pervasive parenchyma. Collateral vascular bundles remain and do not grow together into a compact belt of xylem.

Gnetum grows as lianas and small trees with broad leaves. All species grow in moist tropical climates. The xylem consists of solitary vessels, tracheids and septate tracheids and paratracheal parenchyma. Perforations are simple and foraminate. A special feature are vestured vessel pits and bordered ray pits.

In common for Welwitschia and Gnetum is the presence of gelatinous fibers in the phloem and the cortex.

In conclusion: Anatomical features in the xylem relate all the three families to the angiosperms. Solely the bordered pits indicate a relation to the conifers. It remains unclear to what extent site differences and geographical isolation drove stem evolution in such different directions. 


\subsubsection{Angiosperms: Monocotyledons and their growth forms}

The monocotyledons are extremely manifold. There are approximately 60,000 species within 11 orders. Monocotyledons grow in all vegetation zones from tropical to arid and arctic zones, and in all habitats from extremely dry to submersed sites. Growth forms vary from little herbs to lianas and large trees (palms).

\section{Palms (Arecaceae)}

Within the Arecaceae family, there are approximately 2,600 species. They occur preferentially in tropical regions. A common characteristic for all species is the absence of secondary growth. Described here is the date palm, Phoenix dactylifera. Vascular bundles are irregularly distributed over the whole stem

\section{Macroscopic aspect}

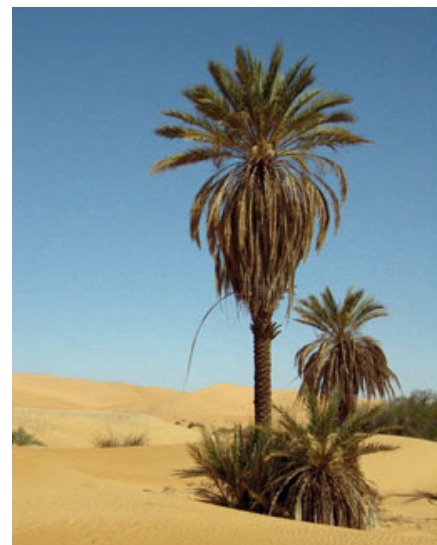

7.258 Date palm (Phoenix dactylifera) in an oasis of the Sahara desert.

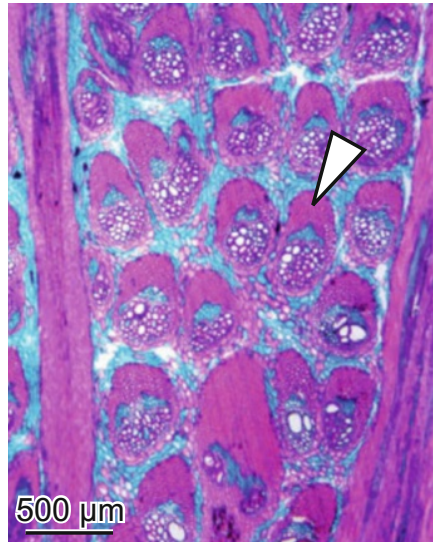

7.259 Irregular distribution of vascular bundles (atactostele) in Phoenix dactylifera.
Presented are exemplarily some few species and growth forms of different taxonomic groups in various habitats. This selection gives an impression of the anatomical variability within the monocots. So far, there are hardly any stem anatomical features observed that are common for the entire group.

cross section (atactostele). Closed collateral vascular bundles contain many small vessels with scalariform pits. The bundles are surrounded by thick-walled sheaths of fibers. See also Tomlinson et al. 2011.

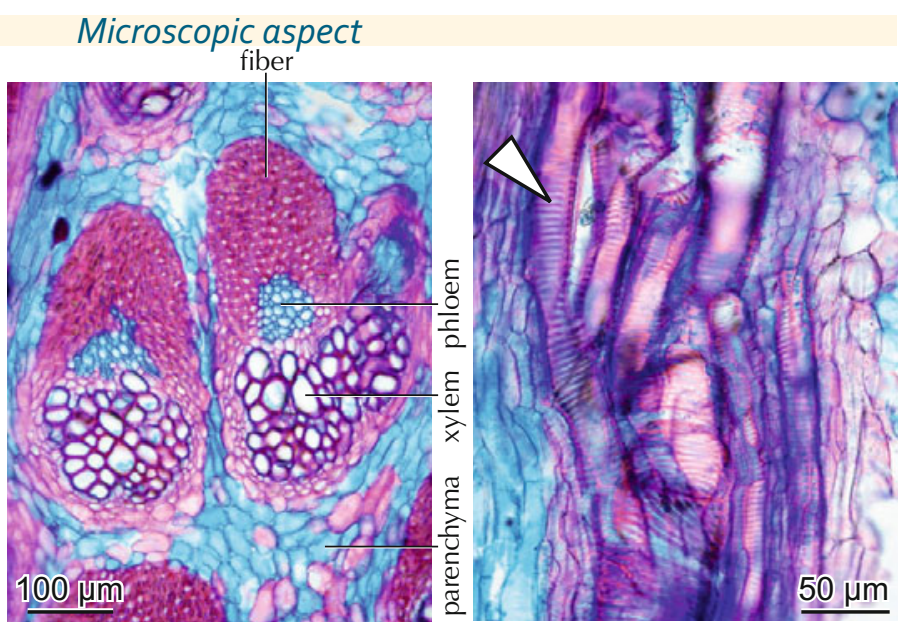

7.260 Closed collateral vascular bundles with dense sheaths in 7.261 Vessels with scalariform pits in Phoenix dactylifera.

\section{Bamboo (Poaceae)}

The more than 1,000 bamboo species occur primarily in southern Asia and South America. Most of the species form heavily lignified, straight stems. Here, the species Phyllostachys bambusoides is anatomically described. Vascular bundles are irregularly distributed over the whole stem cross-section (atactostele). Closed collateral vascular bundles are composed of two large

\section{Macroscopic aspect}

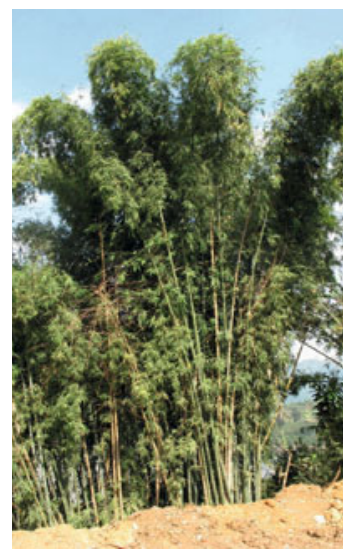

7.262 Bamboo (Chusquea sp.) in the Asian tropics, $20 \mathrm{~m}$ tall.

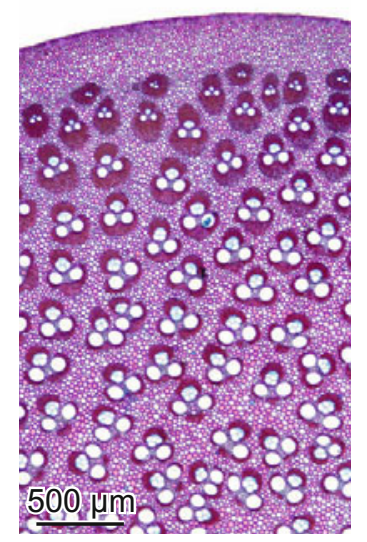

7.263 Irregular distribution of vascular bundles (atactostele) in Phyllostachys bambusoides.

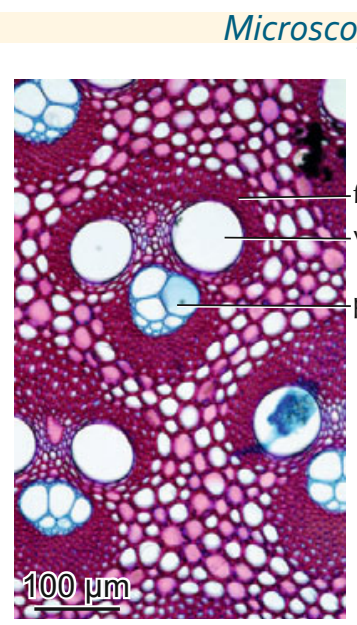

7.264 Closed collateral vascular bundles in Phyllostachys bambusoides. vessels and an external group of phloem. Vessels are characterized by a large perforation plate in almost horizontal position, many small pits perforate lateral vessels. Sieve plates in sieve tubes occur as transversely perforated walls. A thick-walled fiber sheath surrounds vascular bundles. More information in Grosser \& Liese 1971.

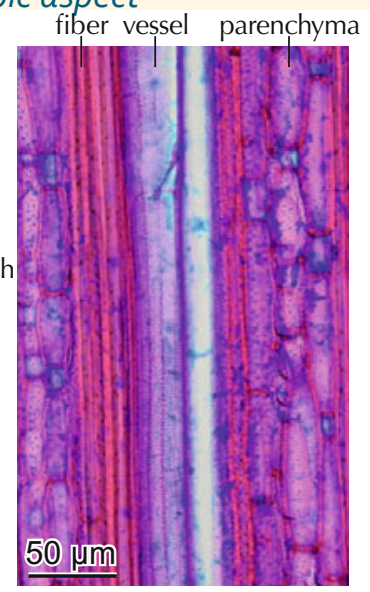

7.265 Vessel with small pits, fibers and parenchyma cells in Phyllostachys bambusoides.

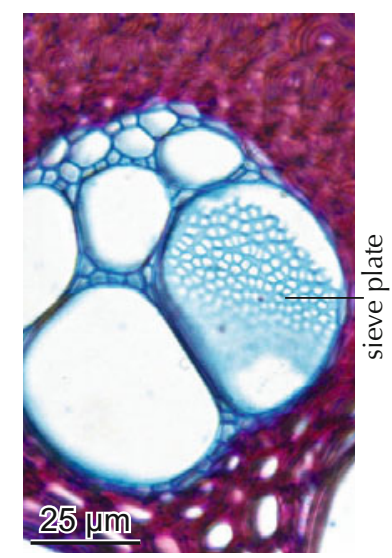

7.266 Phloem with very large sieve tubes in Phyllostachys bambusoides. 
Grass-like terrestrial herbs (Cyperaceae)

More than 5,000 species occur from the tropics to the arctic on extremely dry sites as well as on lake shores. The outlines of culms are triangular, but often roundish. Presented here are one species from a wet site (Carex foetida) and another from a dry, alpine site (Kobresia simpliciuscula).
Secondary growth is absent. The closed collateral vascular bundles are composed of a xylem with a few enlarged vessels and a round group of phloem. The bundles are often surrounded by a belt of thick-walled fibers. See also Metcalfe 1971.
Macroscopic aspect

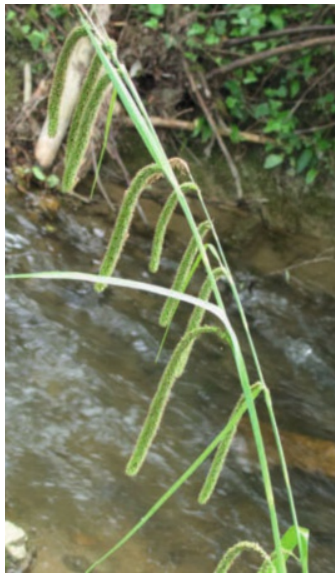

7.267 Carex pendula.

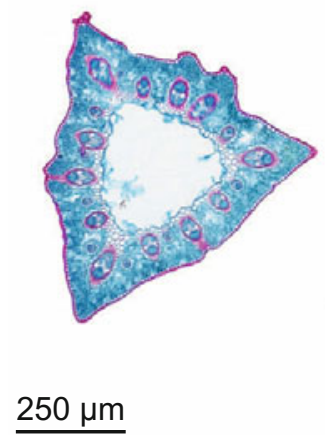

7.268 Triangular culm of the $10 \mathrm{~cm}$-tall grass-like herbaceous Carex foetida on an alpine moist site.

\section{Cross sections of culms}

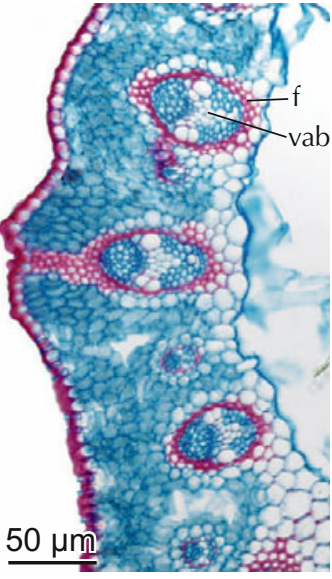

7.269 A belt of thickwalled, lignified fibers surrounds the closed vascular bundles in Carex foetida.

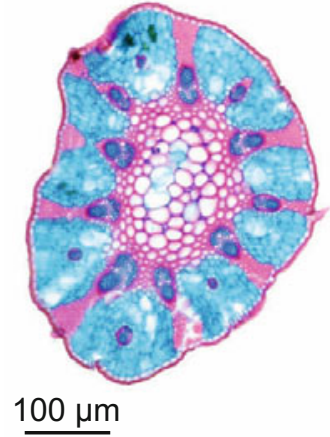

7.270 Round culm of the $10 \mathrm{~cm}$-tall grass-like herbaceous Kobresia simpliciuscula on an alpine, dry meadow.

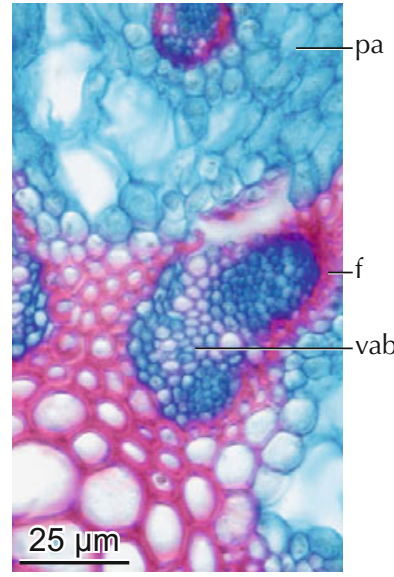

7.271 A belt of thickwalled, lignified fibers surrounds the closed vascular bundles in Kobresia simpliciuscula.

\section{Terrestrial grasses (Poaceae)}

More than 10,000 grass species occur from the tropics to the arctic on extremely dry sites as well as wet sites like lake shores. The outlines of culms are mostly roundish. Presented here are a $30 \mathrm{~cm}$-tall grass species from a ruderal site (Hordeum murinum) and a $4 \mathrm{~m}$-tall species from a moist Mediterranean site (Arundo donax). Secondary growth is absent. The collateral closed vascular bundles are composed of a xylem with a few enlarged vessels and a round group of phloem. A belt of thick-walled fibers often surrounds the bundles. See also Schweingruber \& Berger 2017.

\section{Macroscopic aspect}

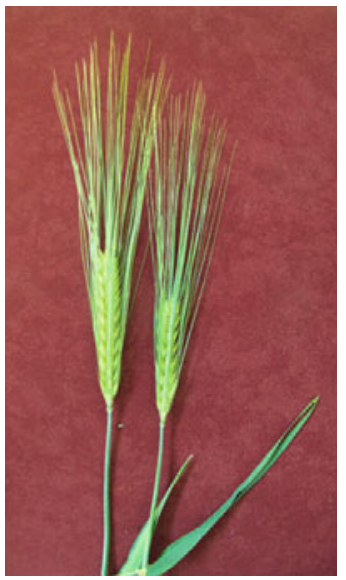

7.272 Hordeum vulgare.

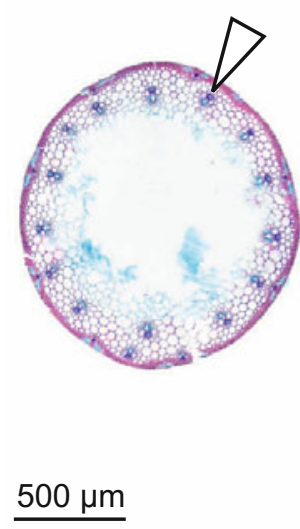

7.273 Round culm of Hordeum murinum, a $30 \mathrm{~cm}$ tall grass. Vascular bundles are circularly arranged (siphonostele).

\section{Cross sections of culms}

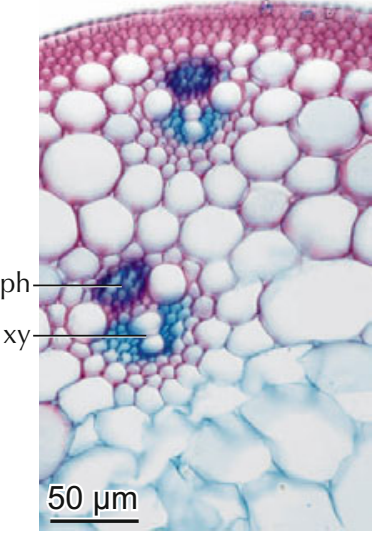

7.274 A belt of thin-walled, lignified fibers surrounds the closed vascular bundles in Hordeum murinum.

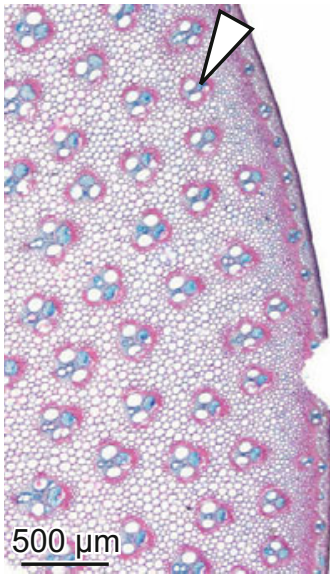

7.275 Arundo donax, a $4 \mathrm{~m}$-tall reed. Vascular bundles are arranged in a Fibonacci spiral pattern (atactostele).

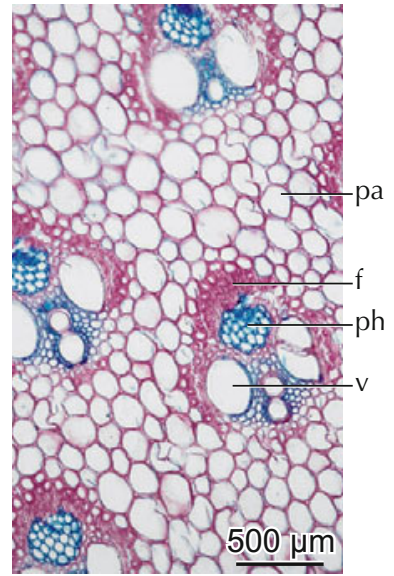

7.276 A belt of thickwalled, lignified fibers surrounds the closed vascular bundles in Arundo donax. 


\section{Orchids (Orchidaceae)}

Approximately 20,000 autotroph and parasitic species occur from the tropics to the arctic on dry as well as on wet sites. The outlines of culms are mostly roundish. Presented here are a $10 \mathrm{~cm}$-tall upright species from a dry site (Spiranthes spiralis) and a $40 \mathrm{~cm}$-tall species from a moist site (Epipactis atrorubens). The closed collateral vascular bundles are composed of a xylem with a few small vessels and phloem. See also Stern 2014.

\section{Macroscopic aspect}

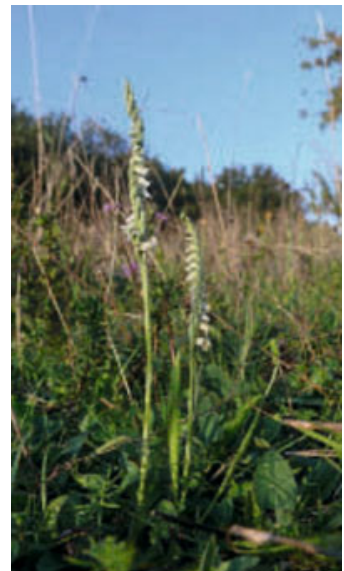

7.277 Spiranthes spiralis, a $10 \mathrm{~cm}$-tall species of a dry site in the temperate zone.

\section{Macroscopic aspect}

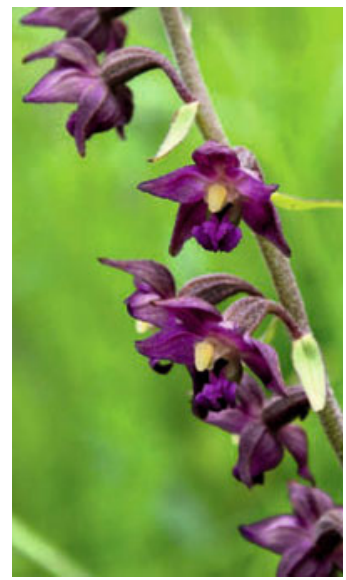

7.282 Epipactis atrorubens, a $40 \mathrm{~cm}$-tall species of a wet site in the temperate zone. Photo: L.B. Tettenborn, Wikimedia Commons, CC BY-SA 3.0
Cross sections of a culm

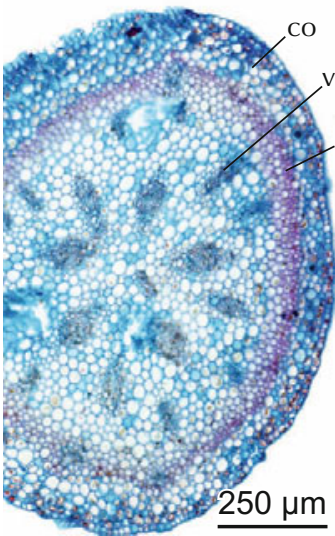

7.278 Vascular bundles are irregularly distributed across the whole stem of Spiranthes spiralis.

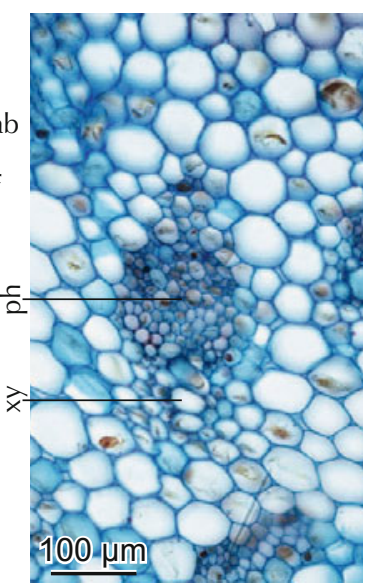

7.279 Xylem and phloem are anatomically not distinctly separated in the vascular bundle of Spiranthes spiralis.

\section{Cross sections of a bulb}

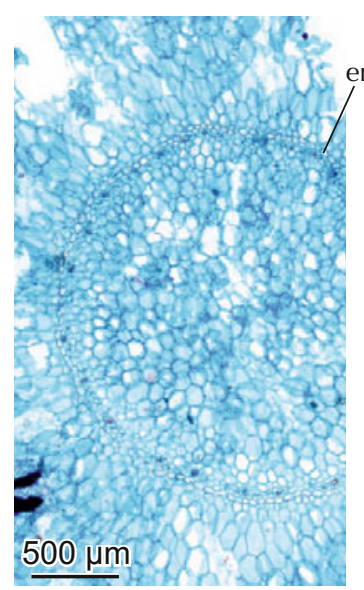

7.280 An endodermis and circularly arranged vascular bundles separate the pith and the cortex in Spiranthes spiralis.

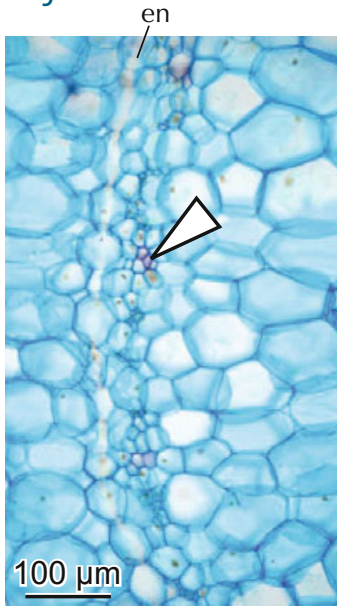

7.281 Rudimentary vascular bundles inside an endodermis in the bulb of Spiranthes spiralis.

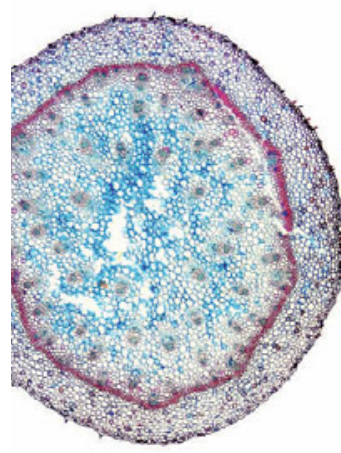

$1 \mathrm{~mm}$

7.283 Vascular bundles are irregularly distributed across the whole stem of Epipactis atrorubens.

\section{Sections of a culm}

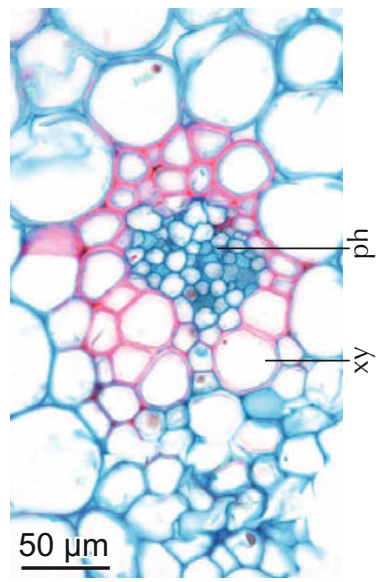

7.284 The xylem surrounds the phloem in the vascular bundle of Epipactis atrorubens.

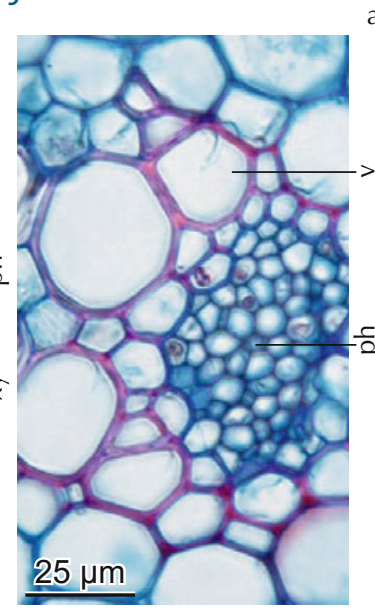

7.285 Phloem and vessels of Epipactis atrorubens. Sieve tubes and companion cells are not differentiated in the phloem. annular thickenings pit

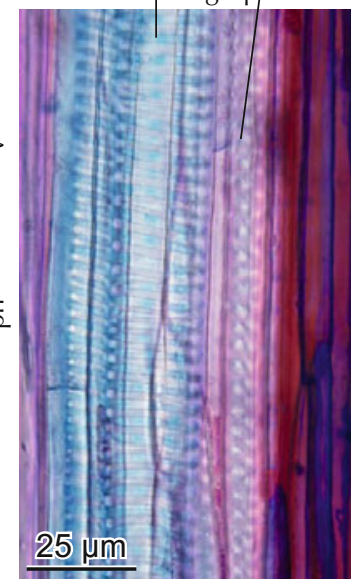

7.286 Annular thickenings in large vessels, and bordered pits in small vessels of Epipactis atrorubens. 
Lianas

Monocotyledonous lianas occur in various families, e.g. in the Dioscoreaceae, Asparagaceae and Poaceae. Some species are perennial, e.g. the Mediterranean spiny Smilax aspera, or the tropical bamboo Chusquea cumingii. Dioscorea communis or

\section{Macroscopic aspect}

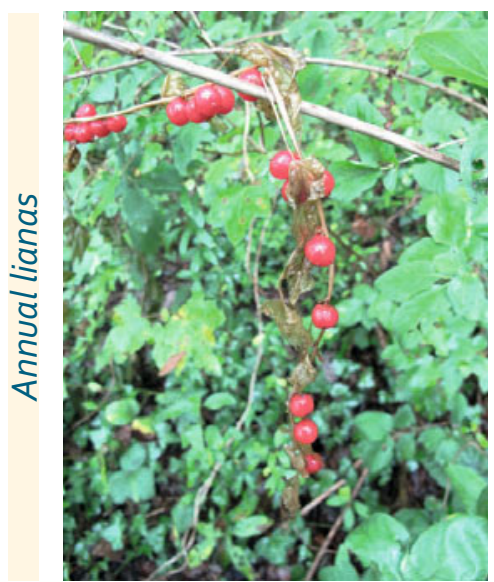

7.287 Dioscor

annual liana.

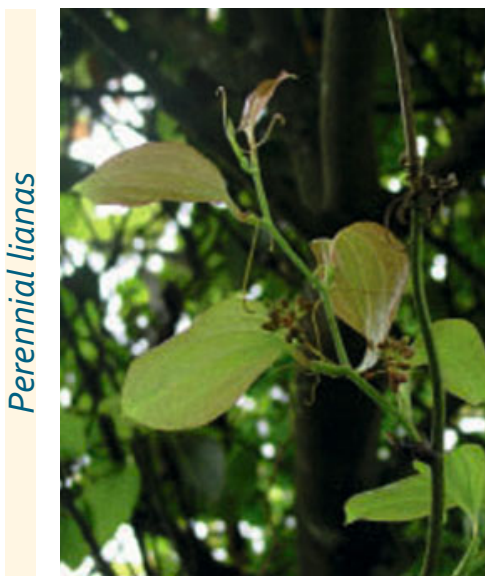

7.291 Smilax azorica. Photo: Capelo via Wikimedia Commons.

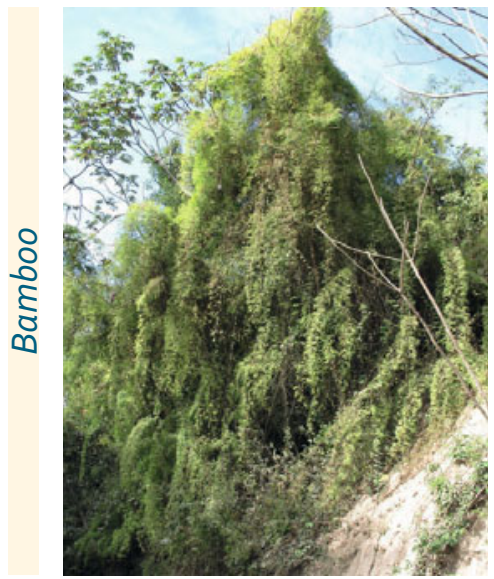

7.295 Chusquea cumingii, a tropical bamboo species.

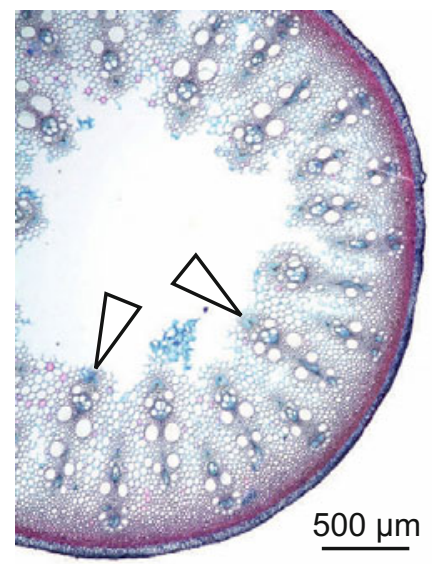

7.288 Annual shoot of Dioscorea caucasica, with circular arranged vascular bundles.

\section{cular bundles in Smilax azorica.}

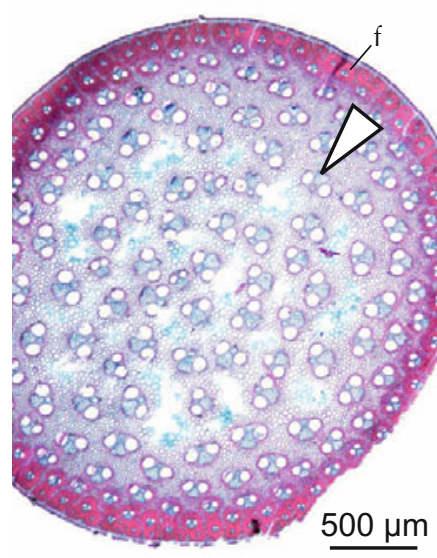

7.296 Irregularly distributed vascular bundles inside of a dense belt of
D. caucasica have permanent subterranean bulbs and annual liana-like shoots. Characteristic for all liana-like species are collateral vascular bundles with large vessels $(150-260 \mu \mathrm{m}$ in radial diameter).

\section{Cross sections of culms/shoots}
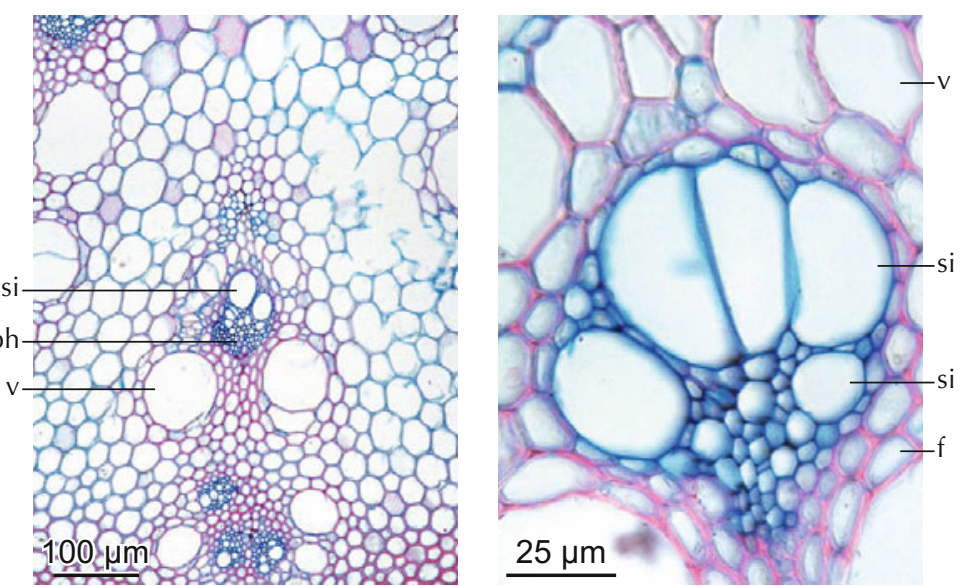

7.289 Closed collateral vascular bundle with large vessels and large sieve tubes in Dioscorea caucasica.

7.290 Phloem with very large and small sieve tubes and small companion cells in Dioscorea caucasica.
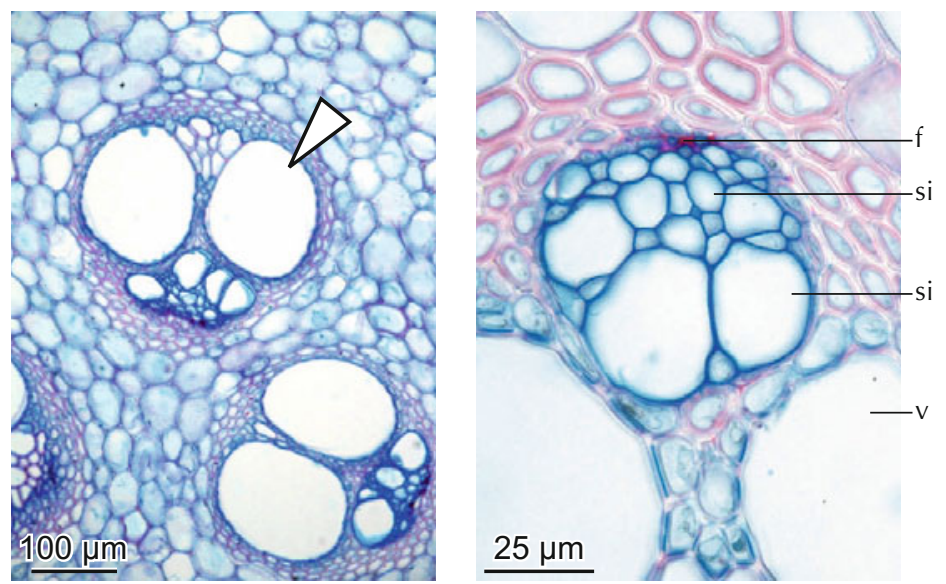

7.293 Xylem of Smilax azorica with very large vessels.

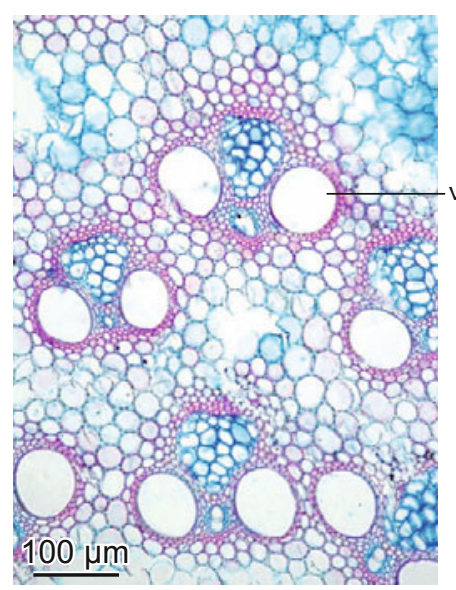
fibers in Chusquea cumingii.
7.297 Xylem of Chusquea cumingii with very large vessels.
7.294 Phloem of Smilax azorica with very large sieve tubes.

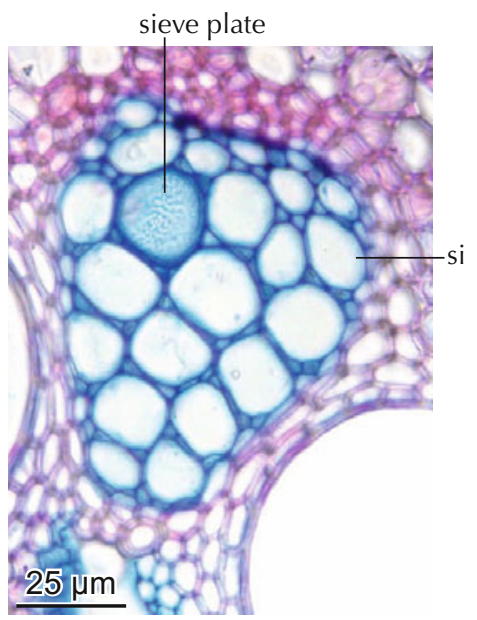

7.298 Phloem of Chusquea cumingii with very large sieve tubes. 


\section{Hydrophytes}

There are species of various families in this life form. Most of them are distributed worldwide in fresh and marine aquatic environments. Presented here are two submerse species from the Potamogetonaceae and Zosteraceae and two floating species from the Hydrocharitaceae and Lemnaceae (today included in the Araceae family).

The submerse species have a central strand of conducting tissues inside of a more or less distinct endodermis. Phloem and xylem are difficult to differentiate (use polarized light). Characteristic for all species is the presence of poorly lignified or unlignified aerenchymatic tissues.

Potamogetonaceae are mainly submerse and floating plants in fresh water. The family includes approximately 120 species. Zosteraceae are submerse marine plants. The family includes two species. Hydrocharitaceae are aquatic plants in both fresh water and marine habitats. The family includes approximately 120 species. Lemnaceae are floating hydrophytes. The exact number of species is unknown.

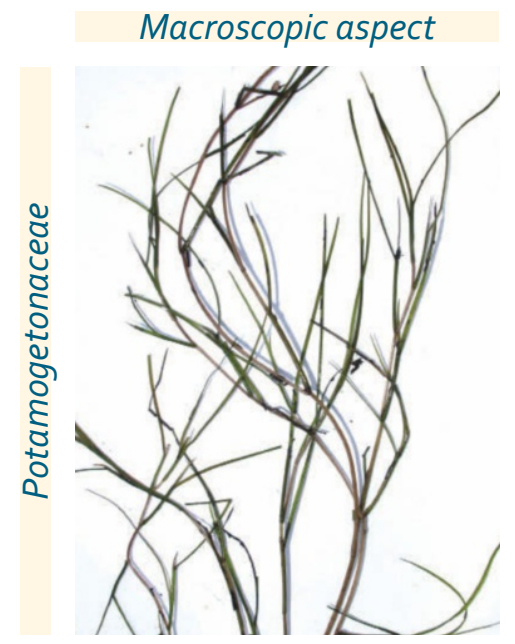

7.299 Potamogeton pectinatus, a $40 \mathrm{~cm}$-long submerse aquatic plant.

natus Stem of Potamogeton pectinatus with a large aerenchymatic cortex and a central strand which is surrounded by a thick-walled endodermis.

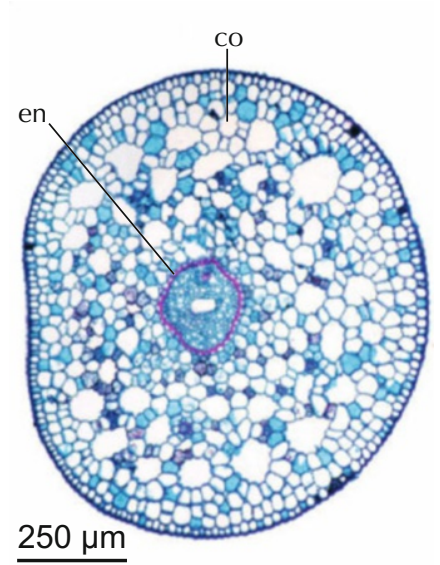

$250 \mu \mathrm{m}$
Cross sections of a shoot

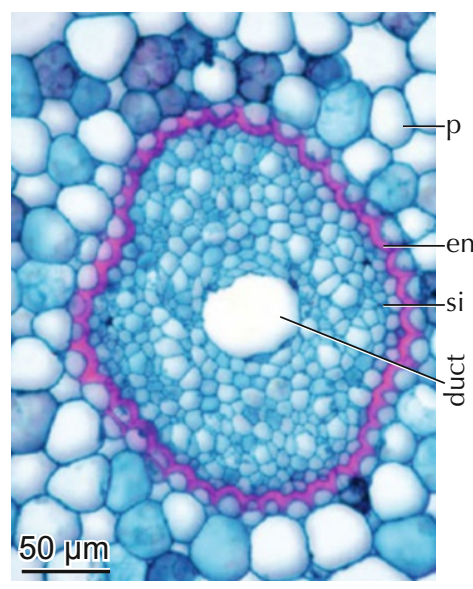

7.301 Central strand of Potamogeton pectinatus consisting of a central air conducting canal, surrounding sieve tubes and parenchyma cells. The unlignified vessels are difficult to recognize (use polarized light).

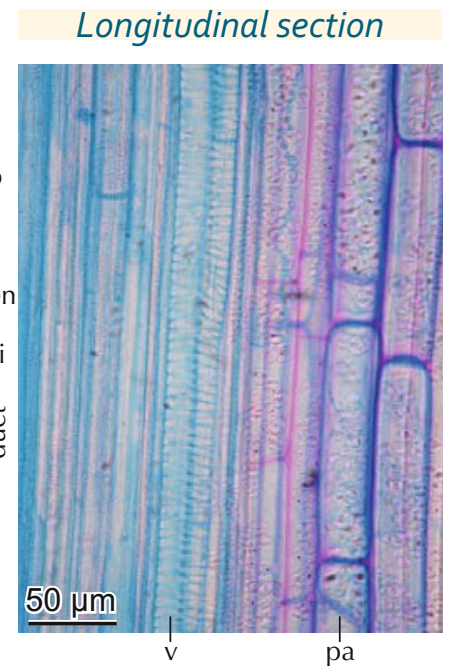

7.302 Vessels with helical thickenings in Potamogeton natans.

\section{Macroscopic aspect}

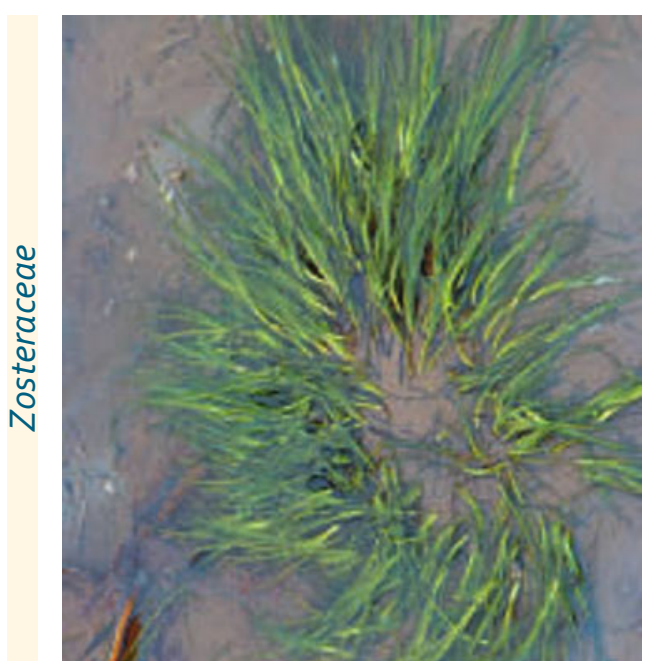

7.303 Zostera marina, a submerse marine plant.

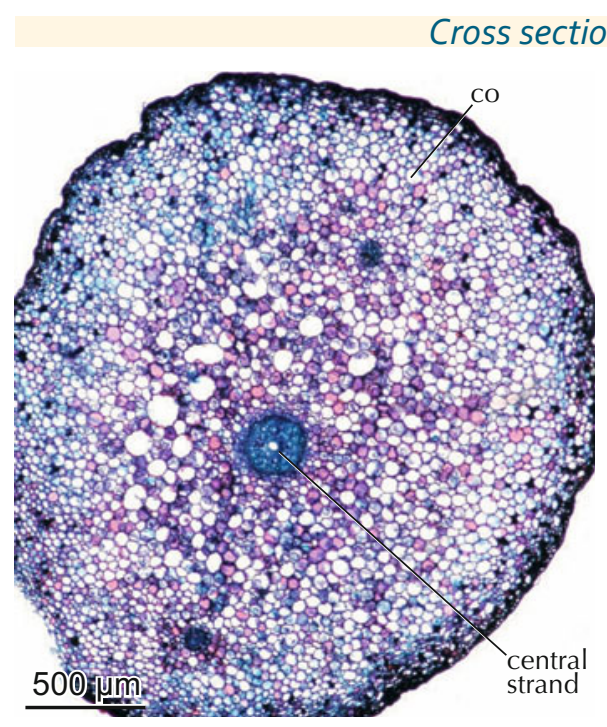

7.304 Stem of Zostera marina with a large parenchymatic cortex and a central strand which is surrounded by a thin-walled endodermis.

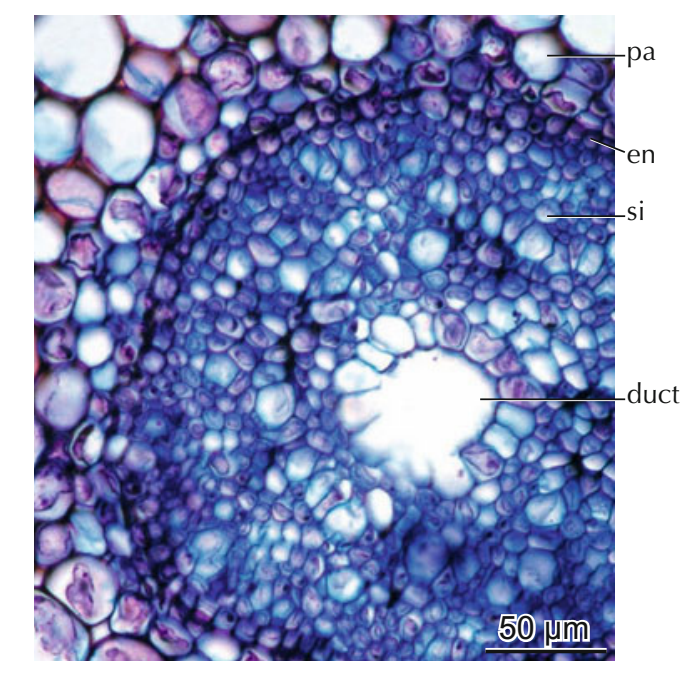

7.305 Central strand of Zostera marina, consisting of a central air-conducting duct with surrounding sieve tubes and parenchyma cells. 
Macroscopic aspect

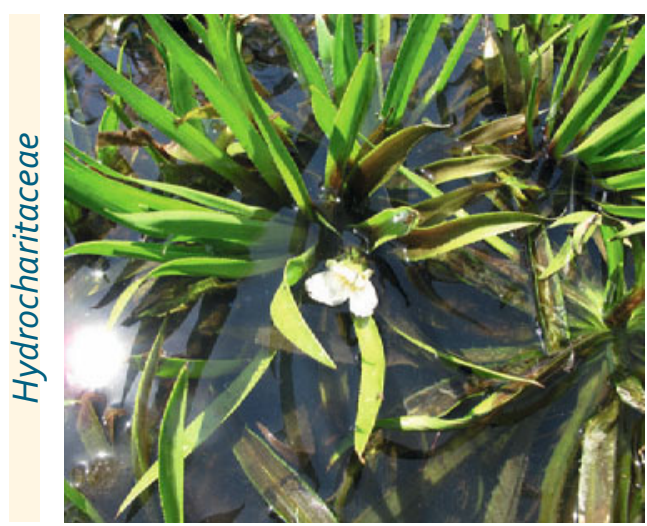

7.306 Stratiotes aloides, a floating aquatic plant.

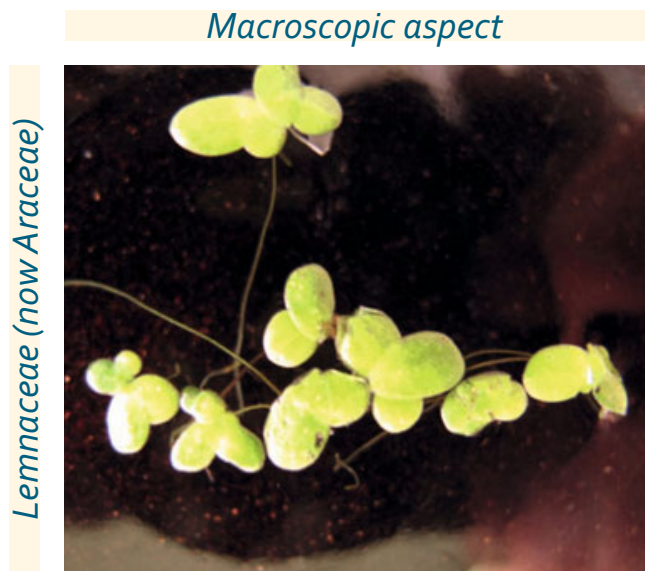

7.309 Lemna minor, a floating aquatic plant.

Cross sections of a culm

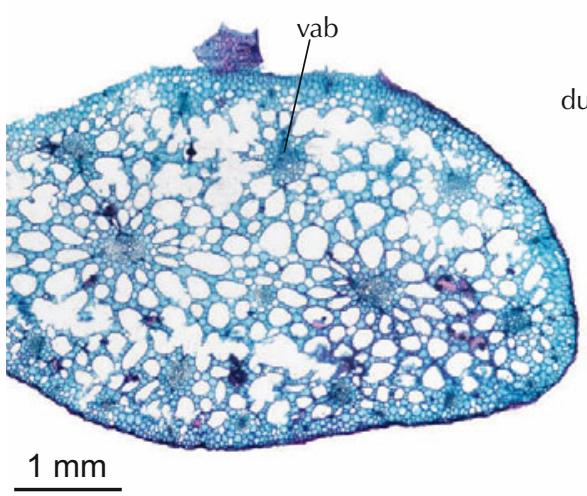

7.307 Culm of Stratiotes aloides. Vascular bundles are irregularly distributed within an aerenchymatic tissue.

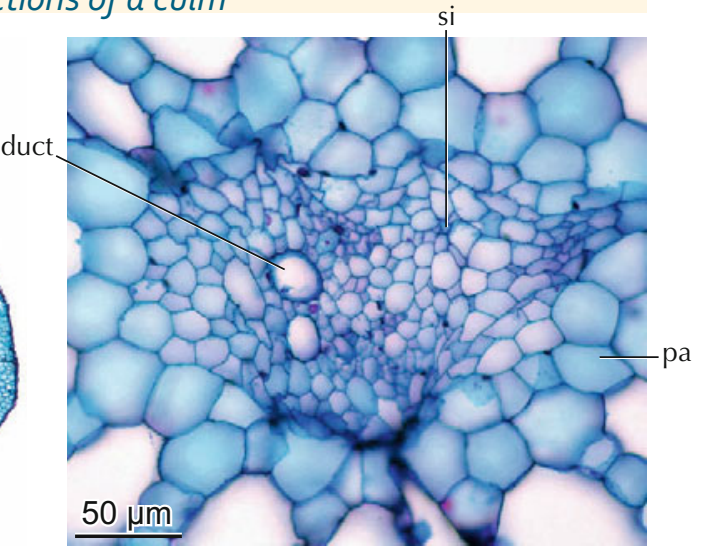

7.308 Vascular bundles of Stratiotes aloides consist of air-conducting tubes with surrounding sieve tubes and parenchyma cells.

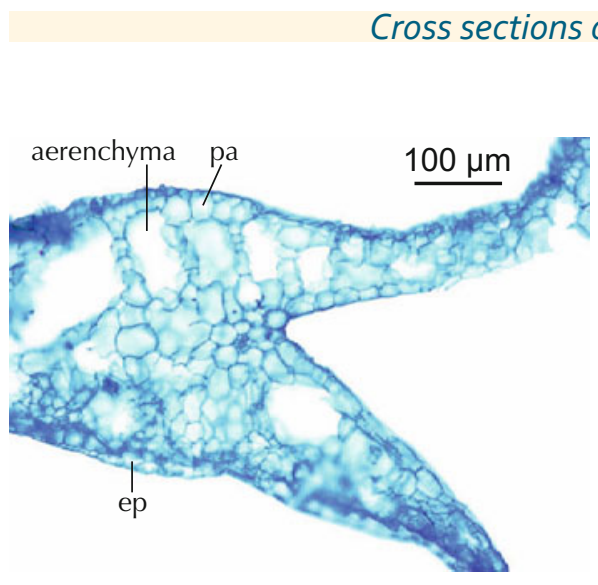

7.310 Plant body of Lemna minor, consisting of a thin-walled aerenchymatic tissue.

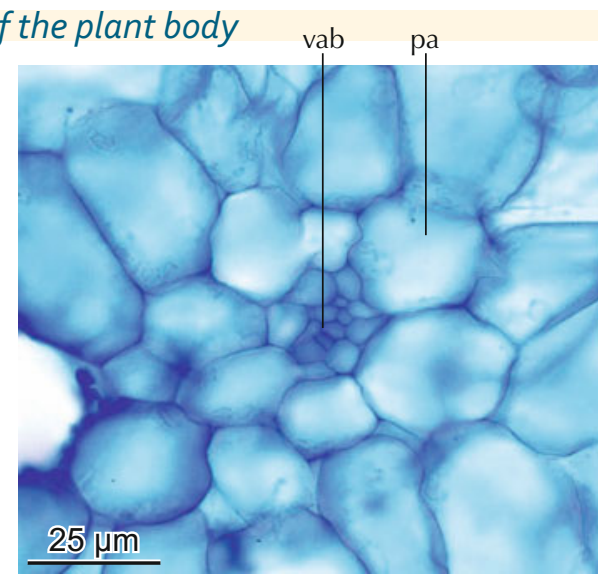

7.311 Heavily reduced vascular bundle in Lemna minor. The central cells probably represent sieve tubes.

Trees and shrubs with secondary growth (Dracaena, Aloe)

Secondary growth is rare in monocots, but it occurs in a few families, e.g. in the Asparagaceae. Secondary growth is different than in dicots. The cambium is located outside of the conducting tissue for water and assimilates. Towards the inside

it produces concentric vascular bundles with a phloem in the center, towards the outside it produces a uniform parenchymatic cortex with a periderm at the periphery. Vessels have round, simple pits. See also Chapter 5.2.

\section{Macroscopic aspect}

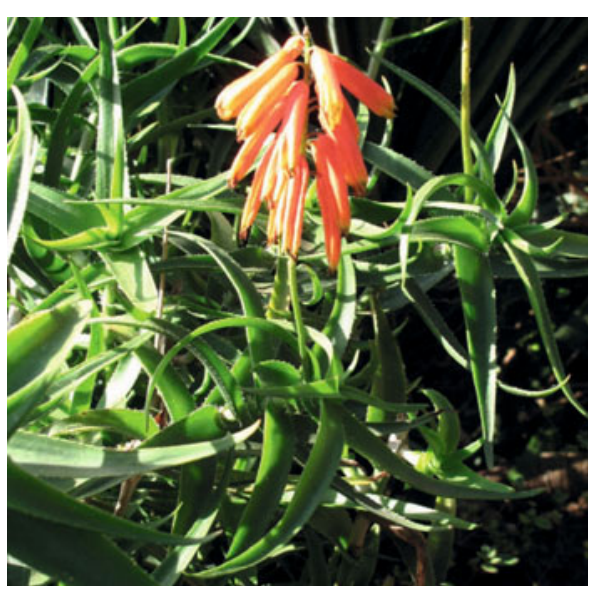

7.312 Aloe sp., a monocotyledonous plant with secondary growth.

\section{Cross sections of a stem}

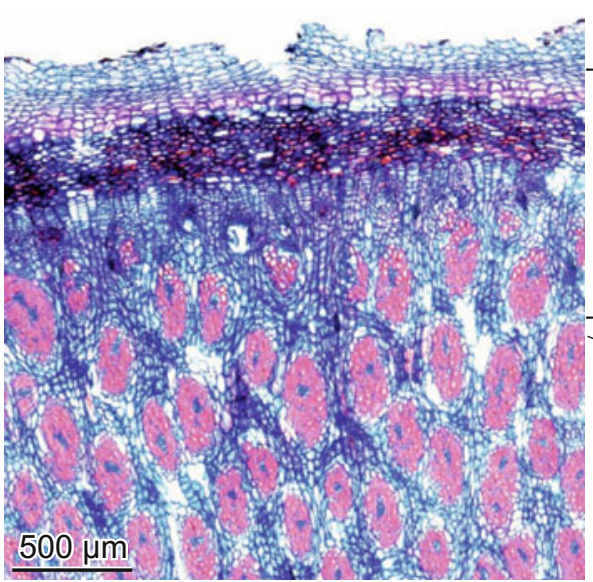

7.313 Xylem, phloem and periderm of Aloe dhufarensis.

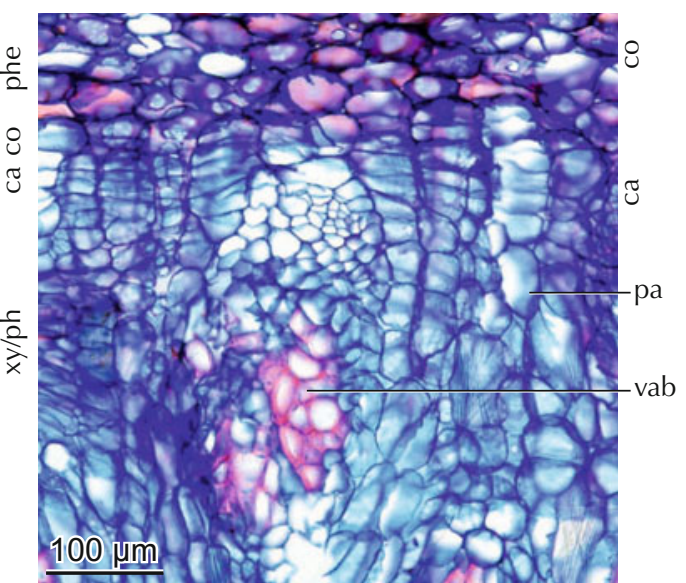

7.314 Formation of a vascular bundle within the cambial zone in Aloe dhufarensis. 


\subsubsection{Angiosperms: Dicotyledons and their growth forms}

The dicotyledons include approximately 210,000 species in the basal orders Magnolids and Eudicotyledons (Rosids and Asterids; Christenhusz \& Byng 2016). Growth forms and life forms cover a wide range (see Chapter 3 ), and vary from little herbs to lianas and large trees. Dicotyledons grow in all vegetation zones from tropical to arid and arctic zones and in all habitats from extremely dry to submerse sites.

\section{Annual herbs (therophytes)}

The height of annual herbs can vary from $3 \mathrm{~cm}$ to more than $4 \mathrm{~m}$. They grow during one vegetation season. However, the growing time within this season differs. Some species grow in very early spring and fulfill their entire life cycle within a few weeks, e.g. Erophila verna, others grow late in the season and last only for one or two months, and some have a longer life span within one year, e.g. Helianthus annuus. The spectrum of the xylem structure varies. It can be very light, with a density of
Exemplarily presented here are some few species of different growth or life forms in various habitats. Excluded are species with successive cambia (for those see Chapter 6.3). The following short presentation will give an impression of the anatomical variability within the dicotyledons of the temperate zone. Taxonomic characteristics on the level of families are presented in Schweingruber et al. 2011 and 2013, and Crivellaro \& Schweingruber 2015.

$0.3 \mathrm{~g} \mathrm{~cm}^{-3}$, thin-walled and hardly lignified (Erophila) or heavy, with a density of $0.1 \mathrm{~g} \mathrm{~cm}^{-3}$, thick-walled and intensively lignified (Euphrasia). The term "annual" can be misleading: not a single species has a life span of an entire year. Common for all annuals is the presence of just one growth ring, which is formed in the limited period of one astronomical year. Presented here are one very small and one very large annual plant.
Macroscopic aspect

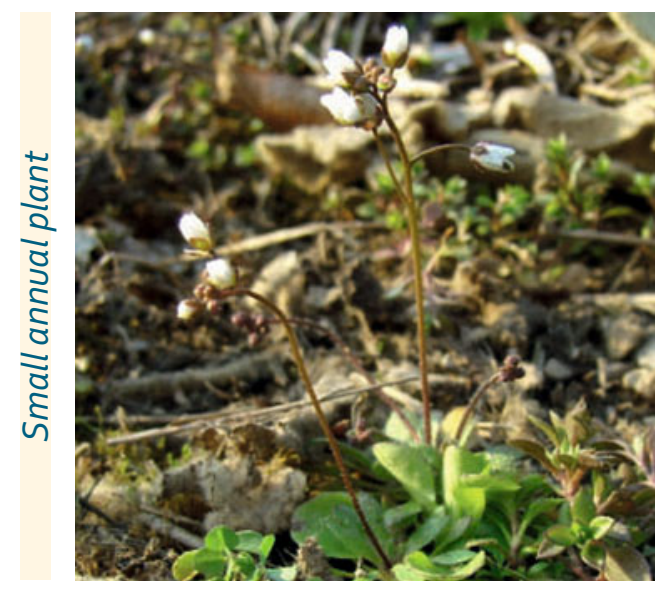

7.315 Erophila verna, a $3 \mathrm{~cm}$-tall plant growing in early spring, with a life span of about four weeks.

Macroscopic aspect

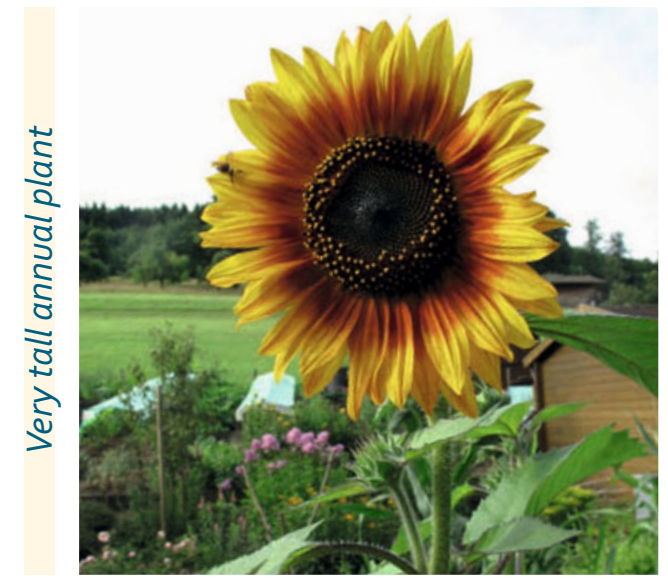

7.317 Helianthus annuus, a $200 \mathrm{~cm}$-tall plant growing in late summer and fall, with a life span of about three months.

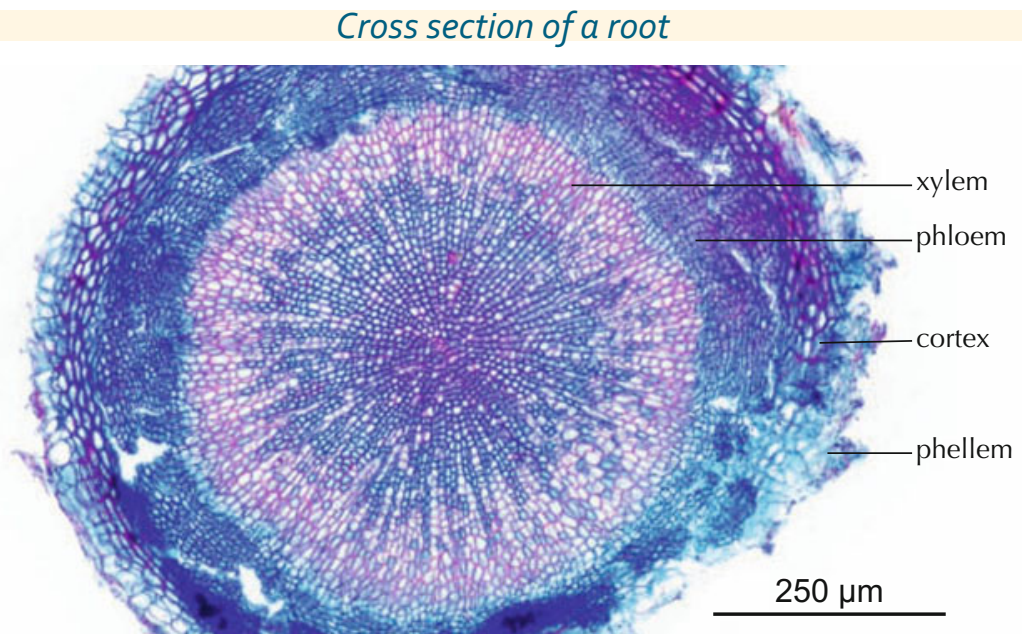

7.316 Root of Erophila verna with poorly lignified cells in the center and lignified cells at the periphery of the xylem. Vessels are extremely small. Rays are absent.

Cross section of a shoot

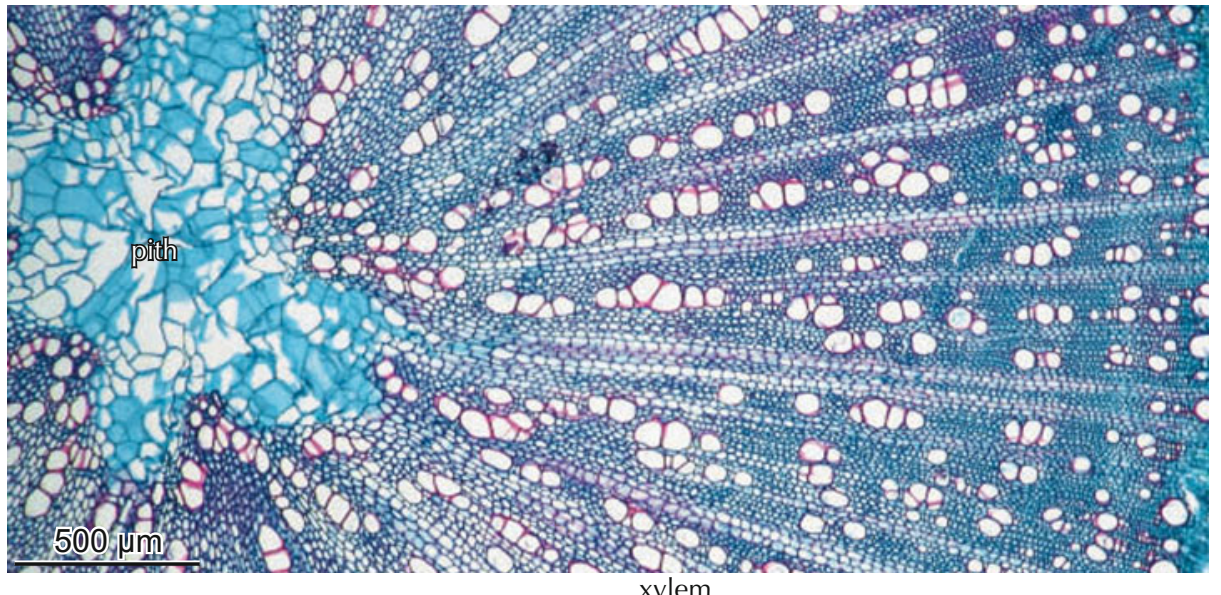

7.318 Xylem of Helianthus annuus with thin- to thick-walled fibers, large vessels and very distinct rays. 
Perennial herbs (hemicryptophytes and geophytes)

As for annual herbs, the height of perennial herbs can vary from $3 \mathrm{~cm}$ to $4 \mathrm{~m}$. Perennial herbs grow over several vegetation periods. The term "herb" is anatomically not clearly defined. Following the common floras (e.g. Aeschimann et al. 2004), included in this term are plants with soft, poorly lignified stems or with short, intensively lignified stems. Transitions from herbs to dwarf shrubs are morphologically continuous. Most perennial herbs fulfill their life cycle during several vegetation periods. Their growth is interrupted during cold or dry seasons (dormant periods). The life span varies from two to approximately 50 years. Annual plants with two growth rings, which germinate in fall, stay dormant during winter and flower in spring (winter annuals), are an exception in temperate regions. The variability in stem structure is as large as in annual plants.
Herb with long rhizomes

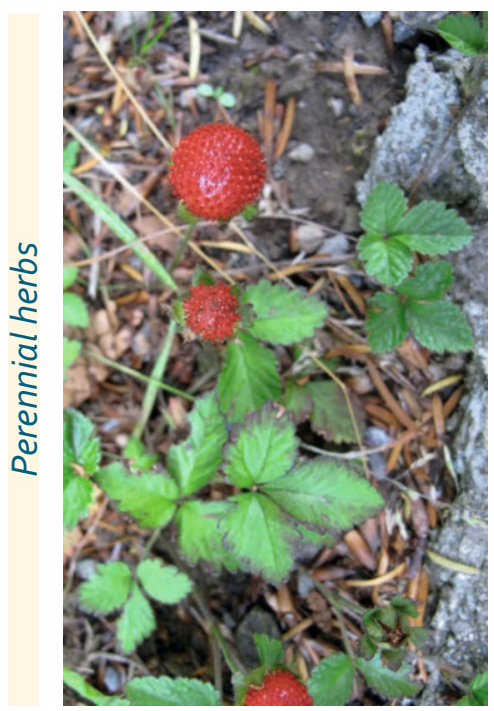

7.319 Duchesnea indica

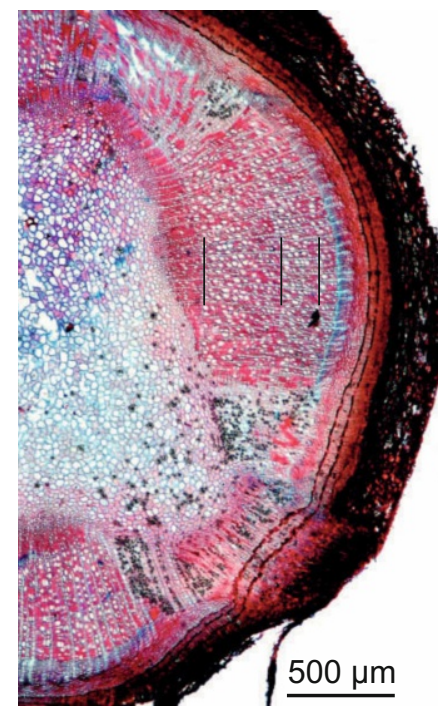

7.320 Rhizome of Fragaria viridis with a diffuse-porous xylem and four annual rings.

\section{Herb with a short rhizome}

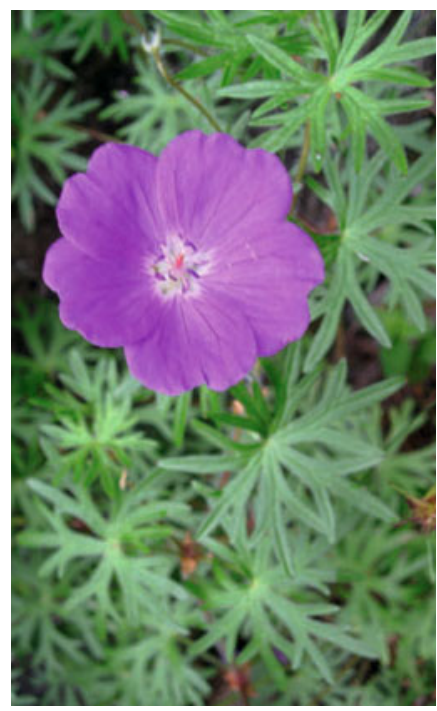

7.321 Geranium sanguineum

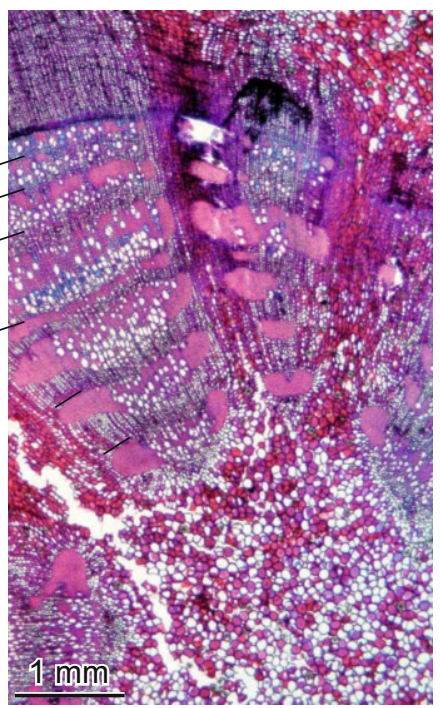

7.322 Rhizome of Geranium sanguineum with a semi-ring-porous xylem with seven annual rings.

\section{Cushion plants with a tap root}

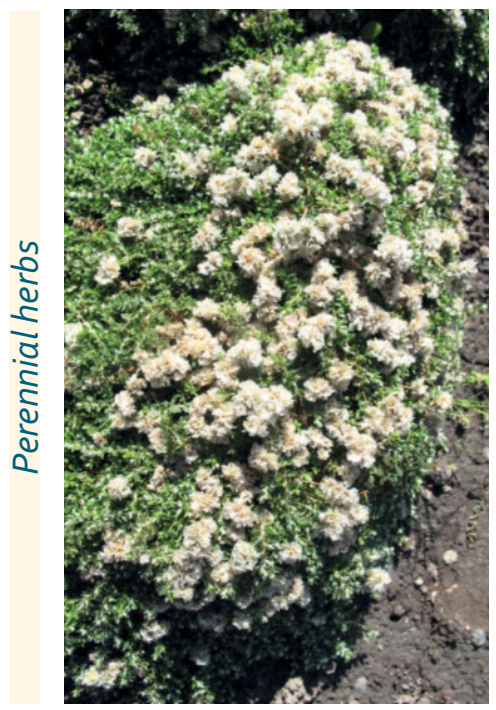

7.323 Paronychia argentea

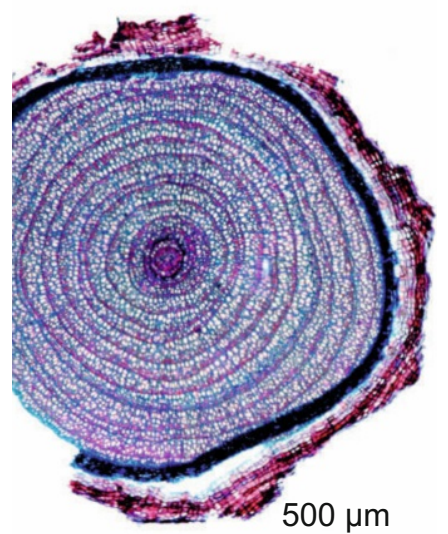

7.324 Taproot of Paronychia argentea with a semi-ring-porous xylem with 15 annual rings.

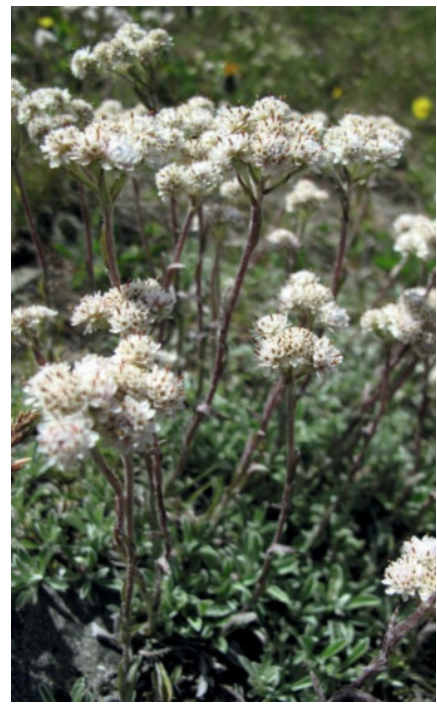

7.325 Antennaria dioica, a small plant of colder climates.

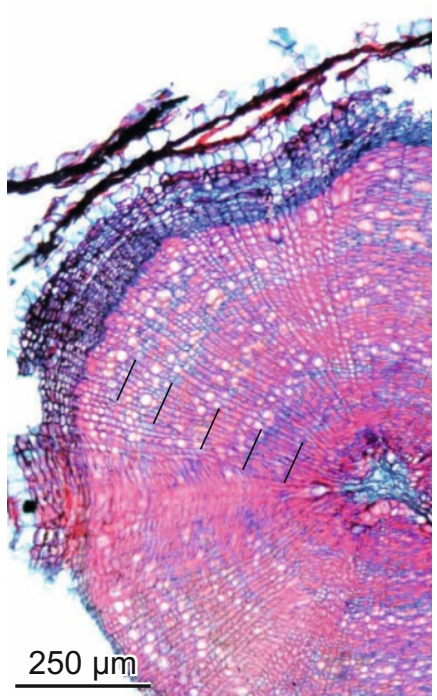

7.326 Taproot of Antennaria alpina with a dense, semi-ring-porous xylem with six annual rings. 
Dwarf shrubs (chamaephytes and nanophanerophytes)

Included are approximately 5-50 cm-tall, largely branched, perennial plants with hard, intensively lignified (woody) stems. Rhizomes and roots live for approximately five to 250 years.

\section{Small costal shrub with a taproot}

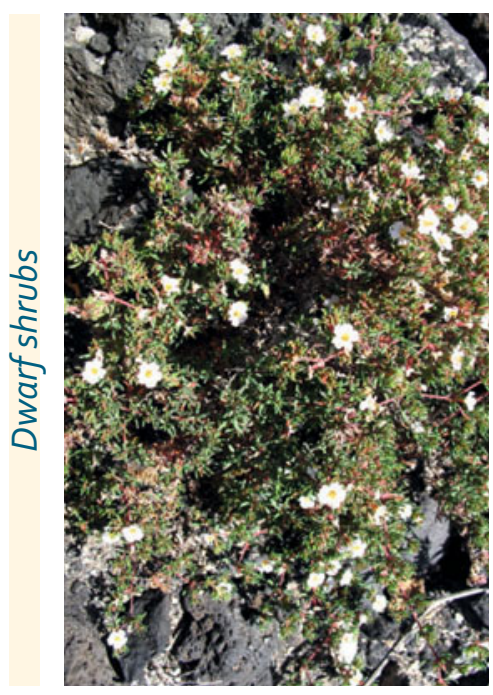

7.327 Frankenia ericoides.

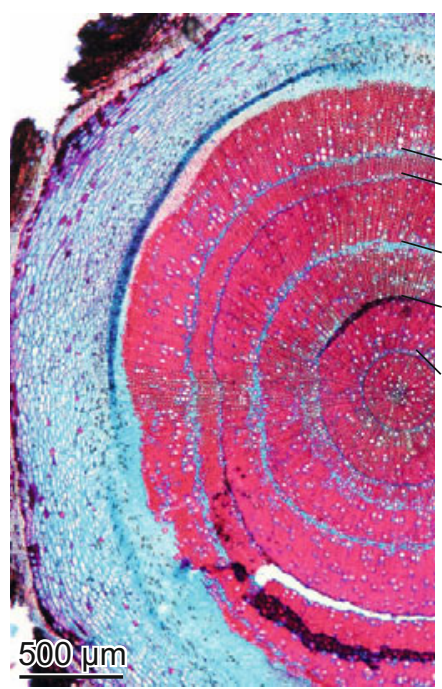

7.328 Taproot of Frankenia pulverulenta with a very dense, diffuseporous xylem with six annual rings.
Prostrate dwarf shrub

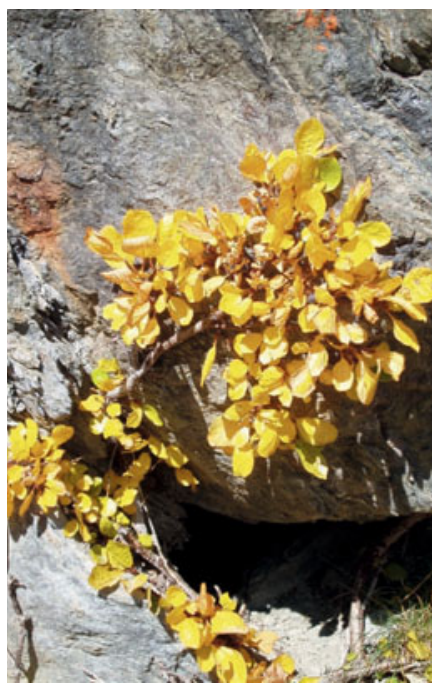

7.329 Rhamnus pumila.

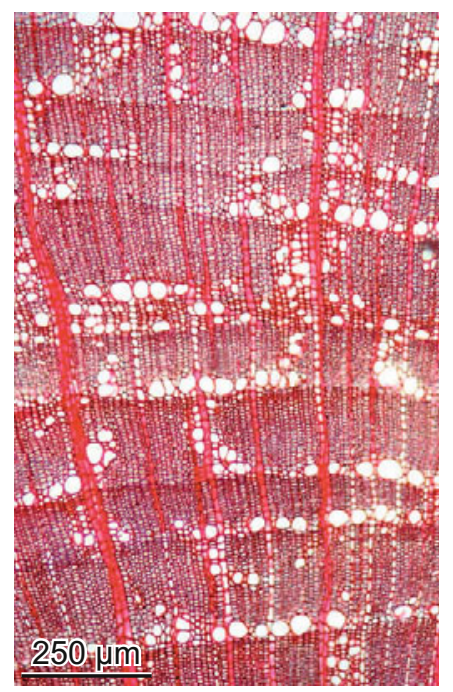

7.330 Stem of Rhamnus pumila with a dense, semi-ring-porous xylem.

Shrubs (nanophanerophytes)

Included are intensively branched, perennial, 50-400 cm-tall plants with hard, intensively lignified (woody) stems. The oldest known individuals reach ages of 800 years (Juniperus sibirica).

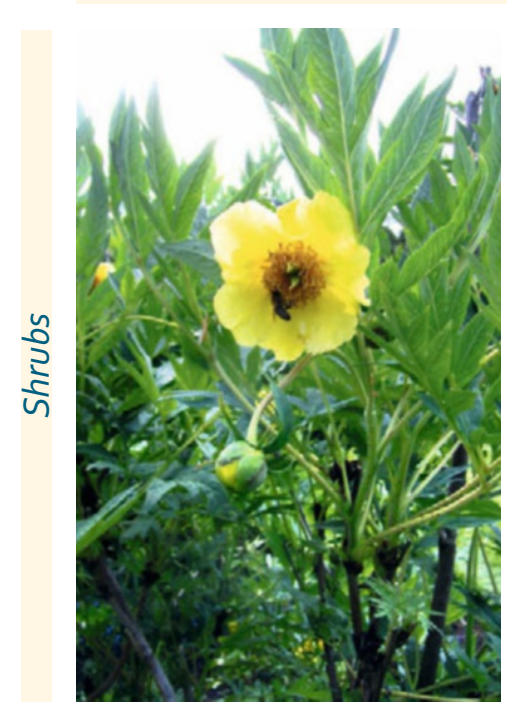

7.331 Paeonia lutea.
One meter-tall shrubs

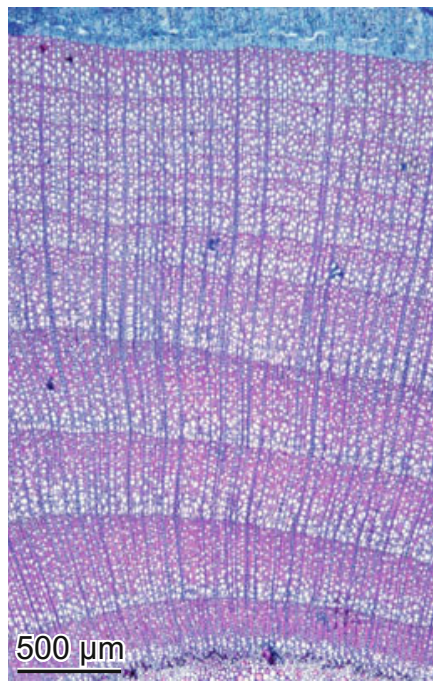

7.332 Stem of Paeonia suffruticosa with a semi-ring-porous xylem.

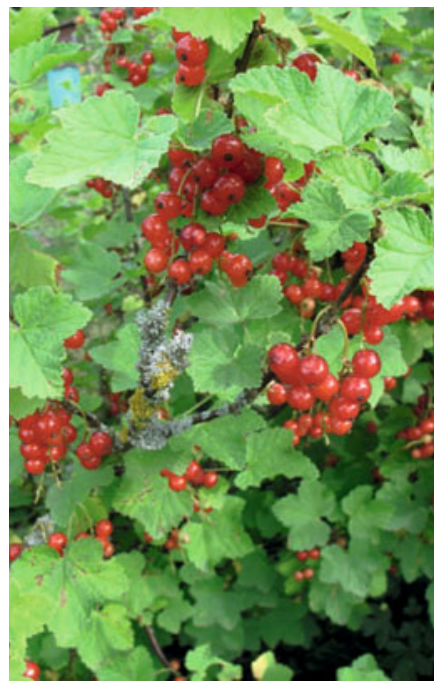

7.333 Ribes rubrum

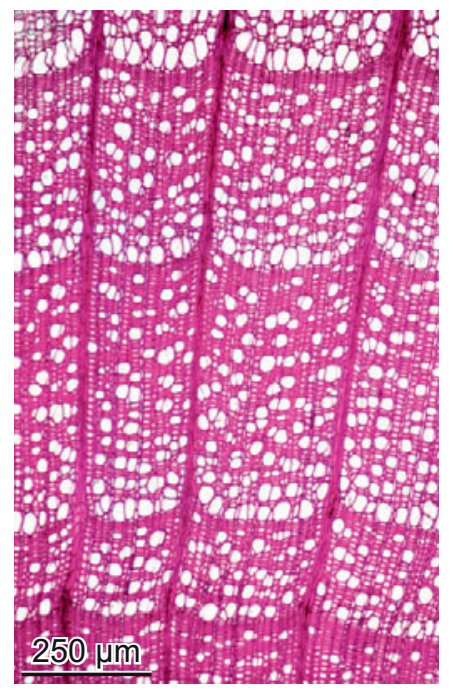

7.334 Stem of Ribes rubrum with a semi-ring-porous xylem. 
Trees (phanerophytes)

Included are perennial plants with one basal stem, more than $4 \mathrm{~m}$ height, with hard, intensively lignified (woody) stems. They can reach ages up to 5,000 years (Pinus longaeva).

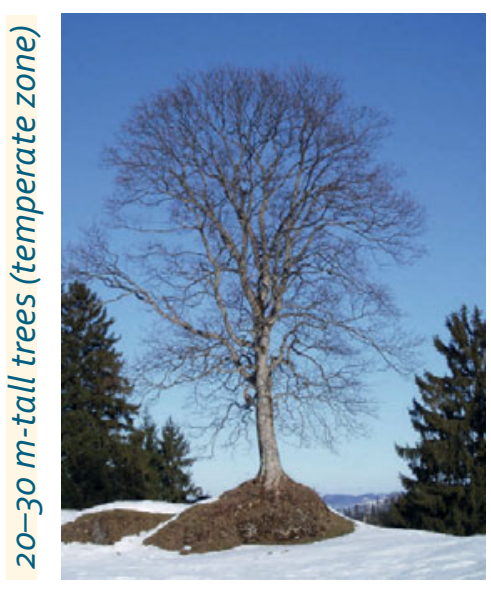

7.335 Acer pseudoplatanus

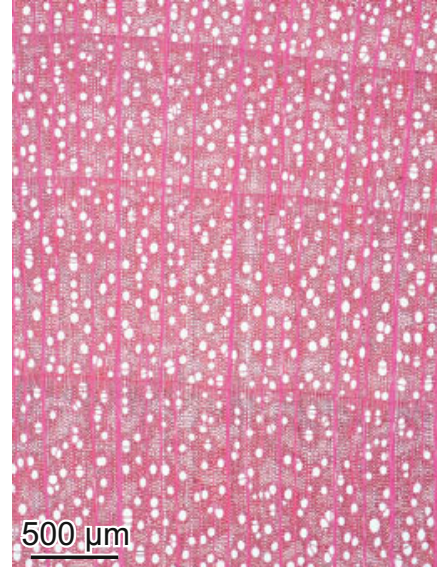

7.336 Diffuse-porous xylem with small vessels in Acer campestre.

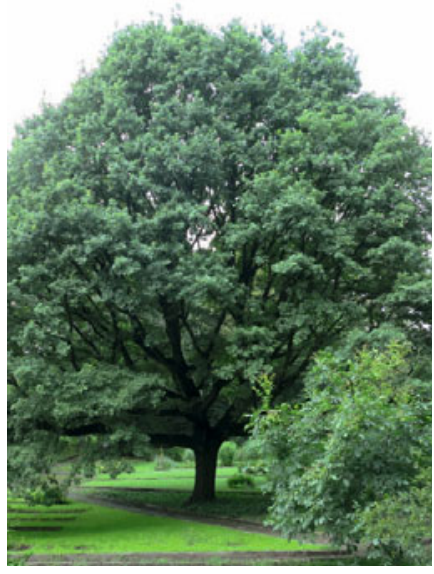

7.337 Quercus robur

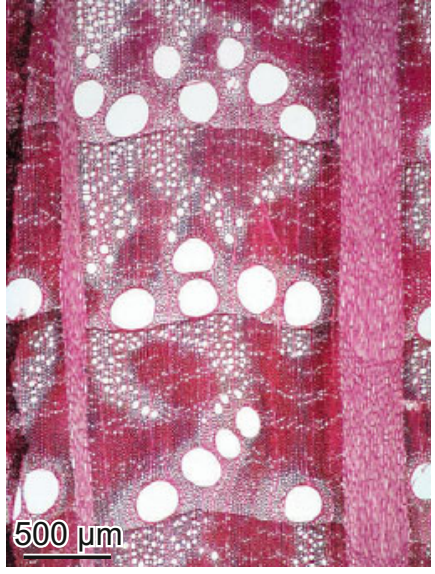

7.338 Semi-ring-porous xylem in Quercus robur.

Lianas

Included here are annual and perennial plants which need support from other plants to grow upwards. Characteristic for all lianas is the presence of large vessels. However, the real

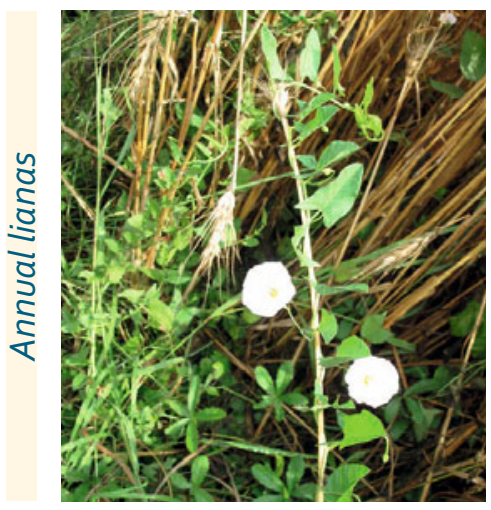

7.339 Calystegia arvensis on cereal stem.

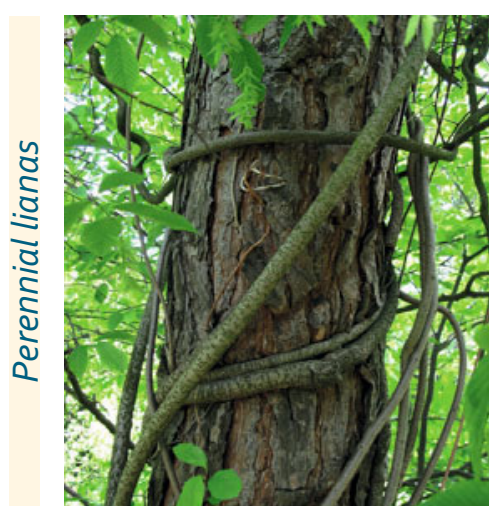

7.343 Celastrus flagellaris on a tree stem in the temperate zone.

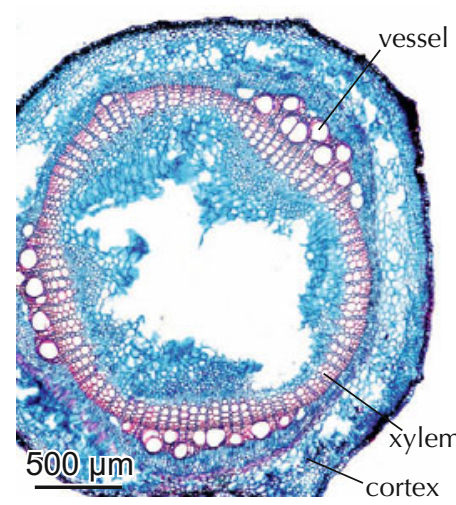

7.340 Partial ring with large vessels in Calystegia arvensis. It is formed in the same year as the closed ring.

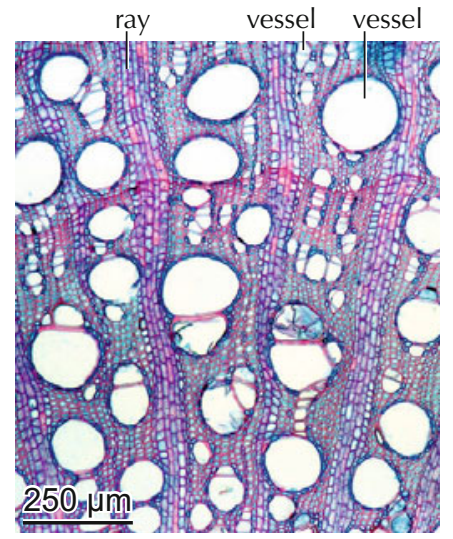

7.344 Diffuse-porous xylem with large and small vessels in Celastrus flagellaris.

demand for water conductance is related to the occurrence of transpiration stress.

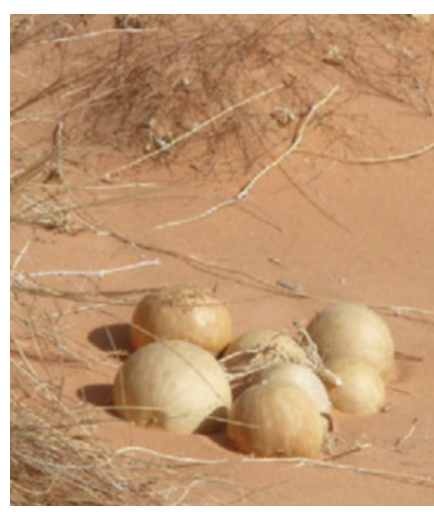

7.341 Citrullus colocynthis, a prostrate liana in the extreme desert.

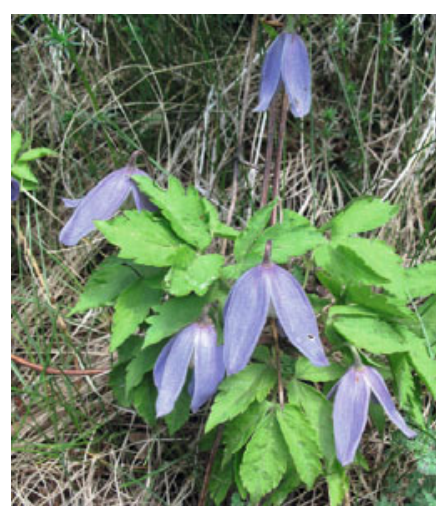

7.345 Clematis alpina, one of the few lianas in subalpine and boreal/ arctic environments.

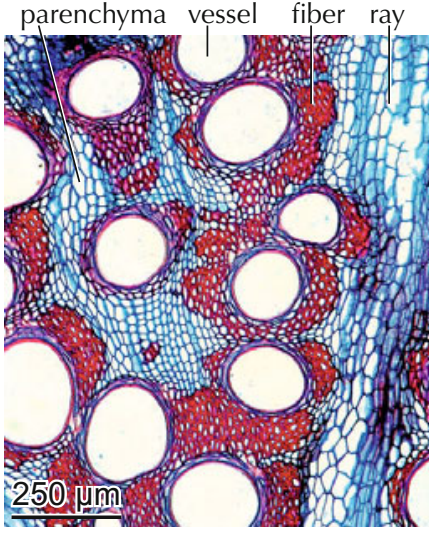

7.342 Heterogeneous tissue with large vessels (active only in the short rainy periods) in Citrullus colocynthis.

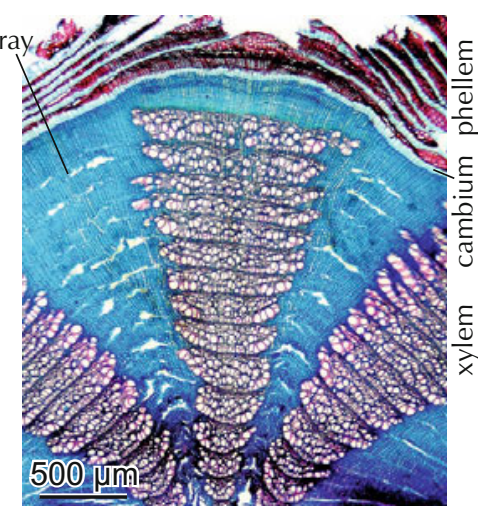

7.346 Semi-ring-porous xylem in Clematis alpina, with a large earlywood containing many vessels. 


\section{Succulents}

Included are annual and perennial terrestrial plants with waterstoring stems, growing mostly on dry sites. Common for all observed species is the extended water-storing tissue, be it in

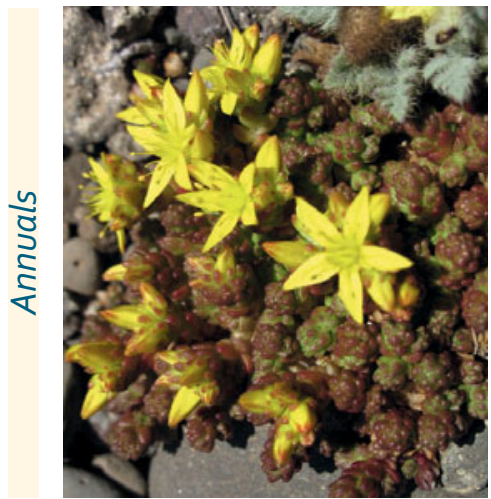

7.347 Sedum annuum, a $3 \mathrm{~cm}$-tal herb with succulent leaves and stems, from the temperate zone at low to high altitudes.

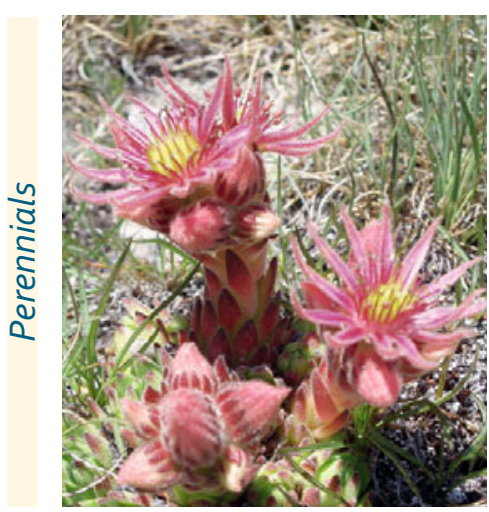

7.351 Sempervivum montanum, an alpine herb with a basic rosette and sporadic flowers, from the temperate zone at high altitudes.

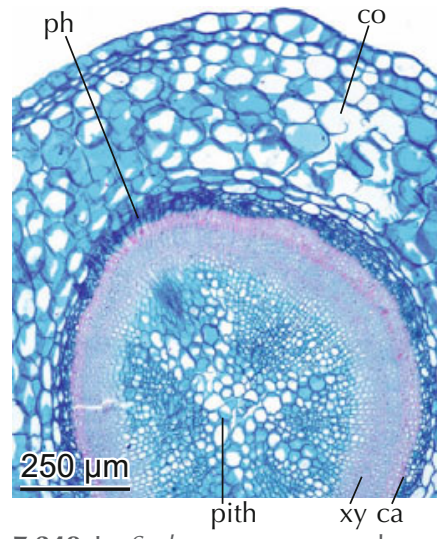

7.348 In Sedum annuum, a dense xylem is surrounded by a small phloem and a very large cortex, consisting of large, parenchymatic cells.

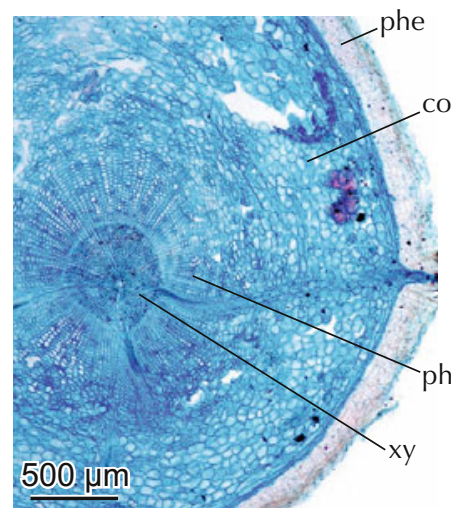

7.352 Root collar of Sempervivum montanum with a small, unlignified xylem, a large phloem and a very large cortex. the pith, the xylem or the bark. Succulent plants occur in many taxonomic units. They are dominant in hot, arid regions, but are also frequent at dry sites in most other biomes.

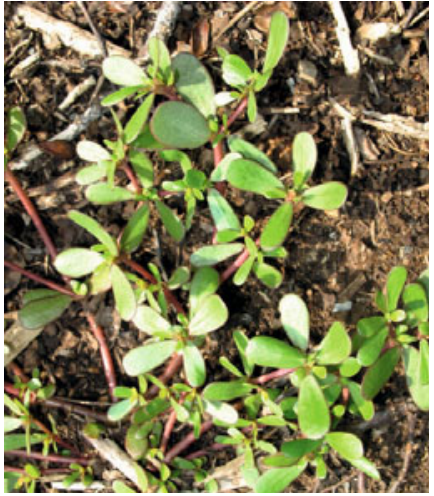

7.349 Portulaca oleracea, a prostrate herb with fleshy leaves and a succulent stem, from the temperate zone at low altitudes and dry sites.

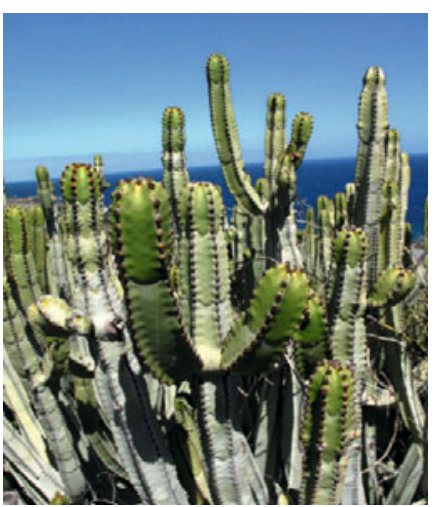

7.353 Euphorbia canariensis, a cactus-like plant, from the subtropical zone at dry sites.

Common for all observed species is the large, water-storing cortex.

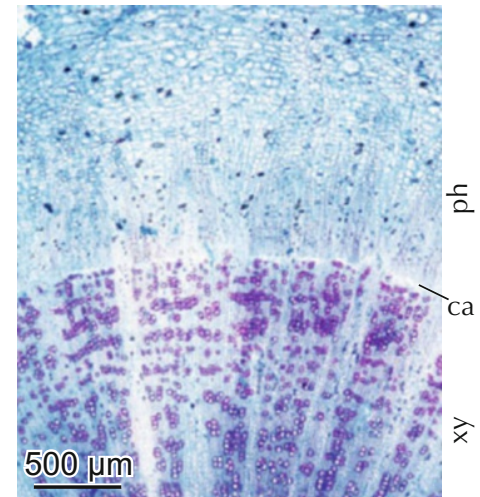

7.350 In Portulaca oleracea, a thinwalled, parenchyma-dominated $x y$ lem is surrounded by an unlignified phloem and cortex.

laticifers

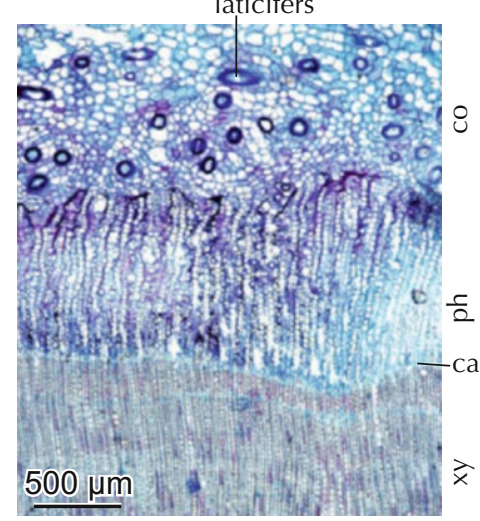

7.354 In Euphorbia canariensis, a xylem with thin-walled fibers and few vessels is surrounded by a very large unlignified phloem and cortex.
Included are annual and perennial terrestrial plants. Growth forms are extremely different, but all of them maintain or complete their metabolism with nutrients from host plants.

\section{Annual parasite}

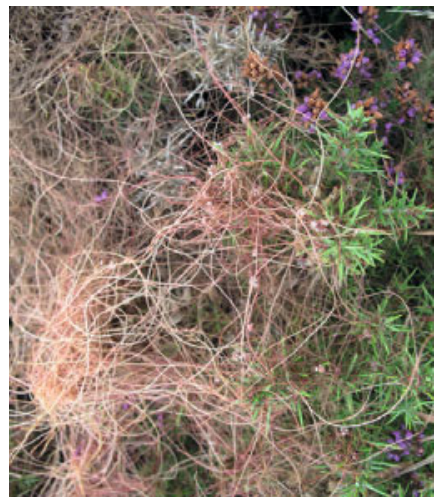

7.355 The thin, annual shoots of Cuscuta epithymum are not self-supporting and attach to photosynthetically active host plants with haustoria.

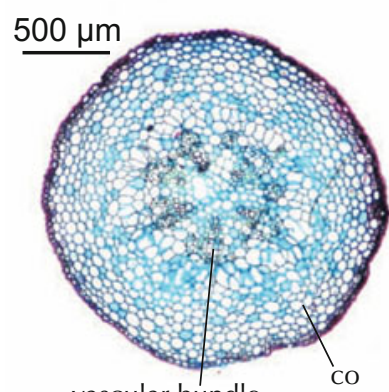

vascular bundle

\section{Semiparasite}

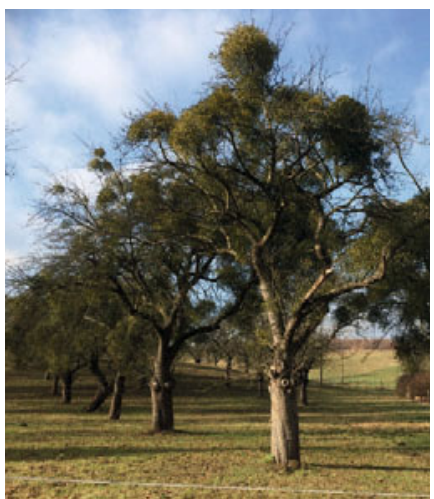

7.357 The perennial Viscum album on apple trees. This semiparasite connects to the xylem of the host plant by haustoria (see p. 78).
7.356 Circular arranged vascular bundles are surrounded by a large thin-walled parenchymatic cortex in Cuscuta sp.

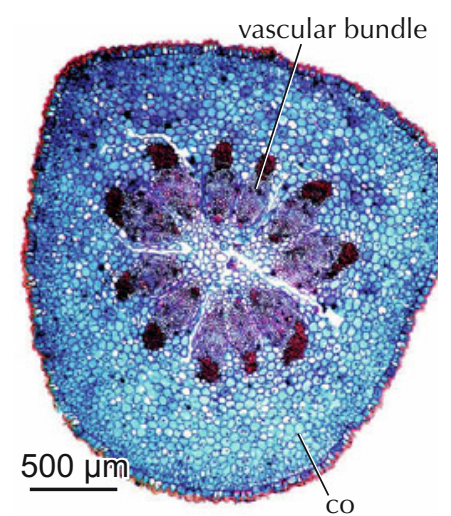

7.358 Annual shoot of Viscum album. Vascular bundles are surrounded by unlignified parenchymatic cortex cells. 


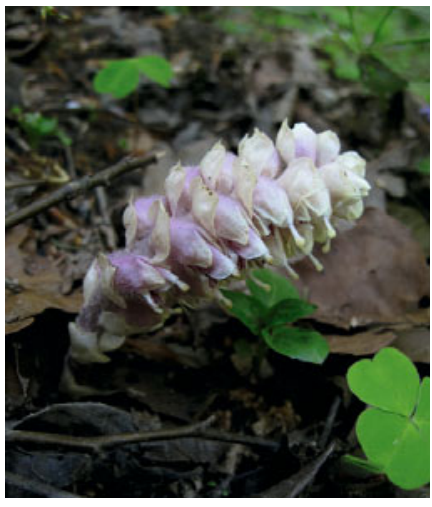

7.359 The chlorophyll-free Lathraea squamaria connects to the xylem of alder roots by haustoria.

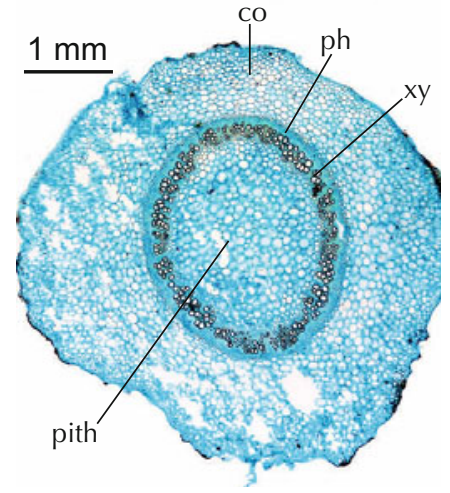

7.360 In Lathraea squamaria, a small ring of lignified vessels surrounds a large pith, and is itself surrounded by a small phloem and a large cortex. This is a typical succulent structure.

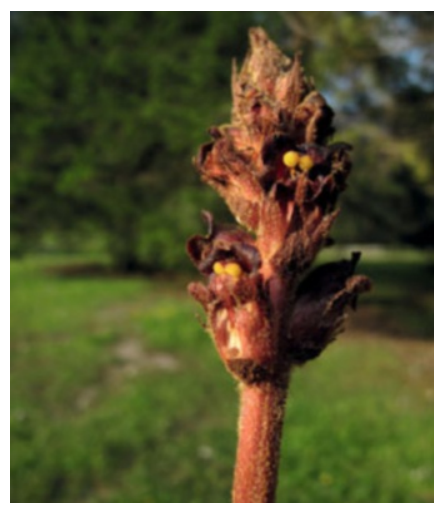

7.361 The chlorophyll-free Orobanche alba is a parasite on several Lamiaceae, and connects to the phloem of the photosynthetically active host plant.

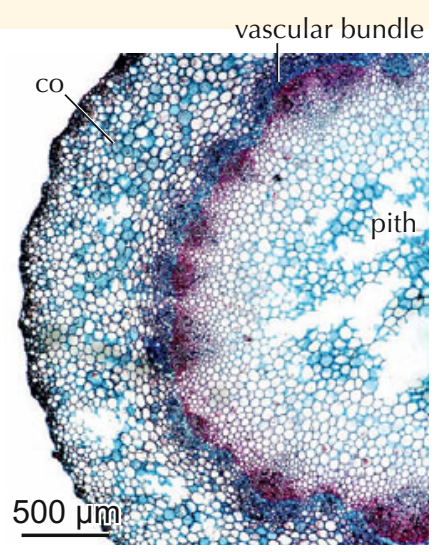

7.362 In Orobanche alba, a ring of vascular bundles surrounds a large pith and is surrounded by a large cortex. This is a typical succulent structure.

\section{Hydrophytes and helophytes}

Included are annual shoots of plants which grow under water (hydrophytes) or are rooted in permanently wet soils (helophytes). Common for all hydrophytes and helophytes are unlignified aerenchymatic tissues. There are no principal anatomical

differences between the two growth forms. Despite the homogeneous, stressful anaerobic environment, specific anatomical differences between species are related to taxonomy.

\section{Hydrophytes}

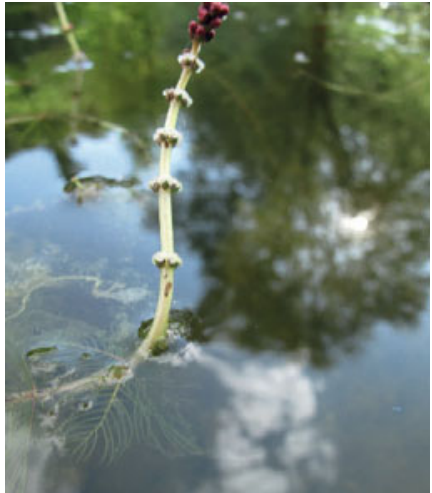

7.363 Flower of Myriophyllum spicatum above the water table. The major part of the plant is submersed.

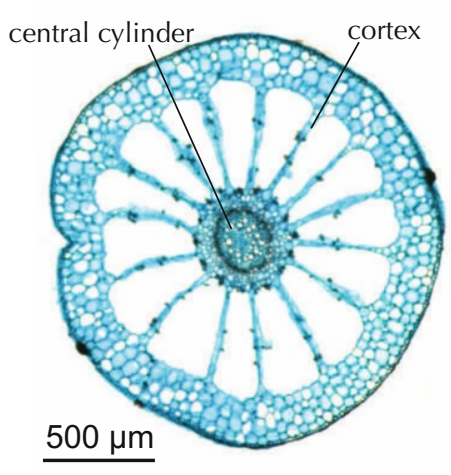

7.364 The central cylinder in Myriophyllum spicatum is surrounded by a cortex with large, uniseriate aerenchymatic tubes.

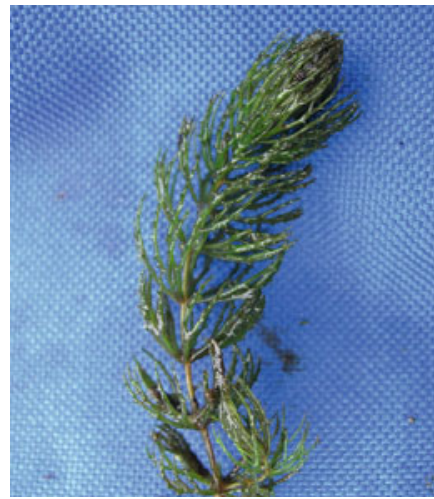

7.365 Submersed shoot of Ceratophyllum demersum.

Hydrophyte

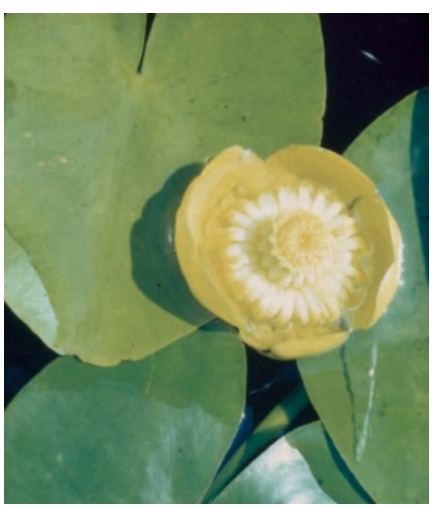

7.367 The floating leaves and flowers of Nuphar lutea root deep in the ground below the water table.

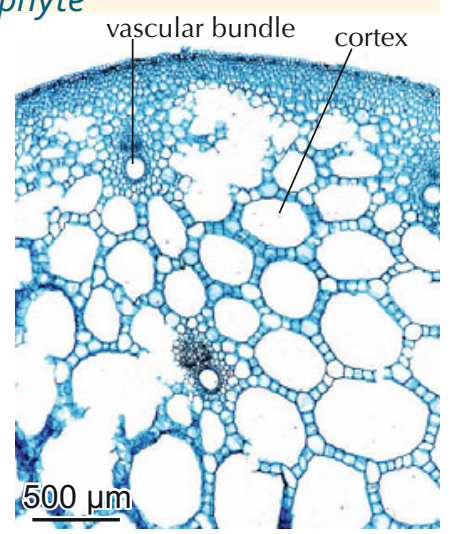

7.368 Single vascular bundles are surrounded by an aerenchymatic tissue in Nuphar lutea.

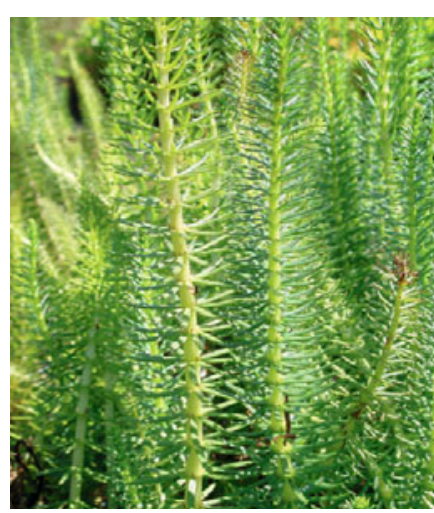

7.369 Annual shoots of Hippuris vulgaris.

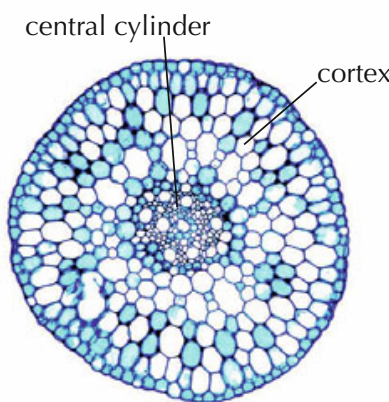

$250 \mu \mathrm{m}$

7.366 The central cylinder in Ceratophyllum demersum is surrounded by a cortex with small aerenchymatic canals between large parenchymatic cells.

Helophyte

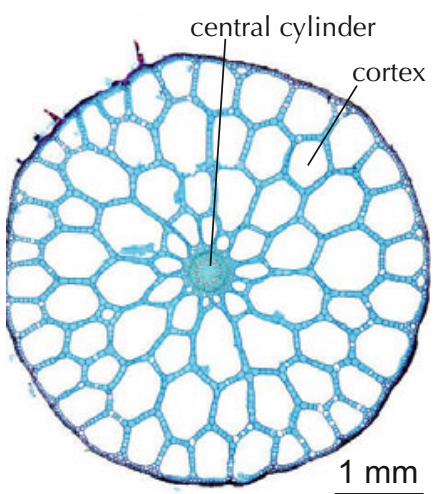

7.370 In Hippuris vulgaris, the small central cylinder is surrounded by a cortex with large aerenchymatic tubes. 
Open Access This chapter is licensed under the terms of the Creative Commons Attribution 4.0 International License (http://creativecommons.org/licenses/by/4.0/), which permits use, sharing, adaptation, distribution and reproduction in any medium or format, as long as you give appropriate credit to the original author(s) and the source, provide a link to the Creative Commons license and indicate if changes were made.

The images or other third party material in this chapter are included in the chapter's Creative Commons license, unless indicated otherwise in a credit line to the material. If material is not included in the chapter's Creative Commons license and your intended use is not permitted by statutory regulation or exceeds the permitted use, you will need to obtain permission directly from the copyright holder. 